\title{
Birds in Literature
}

\section{CHURCHILL}
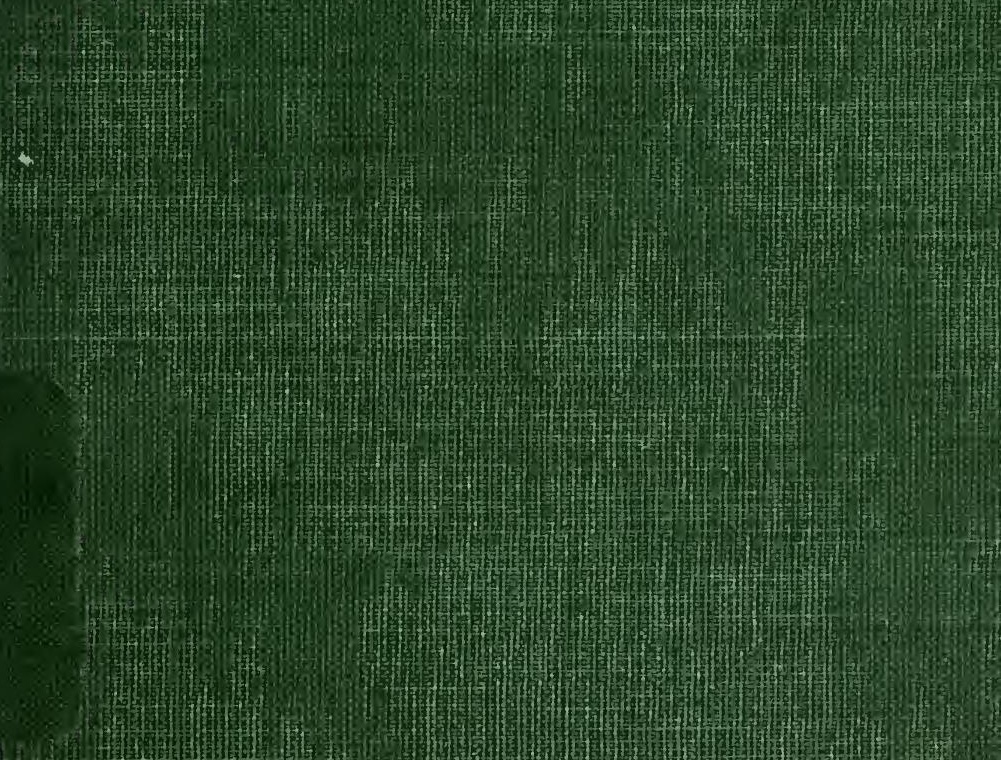







\section{BIRDS IN LITERATURE}



Do you ne'er think what wondrous beings these?

Do you ne'er think who made them, and who taught The dialect they speak, where melodies

Alone are the interpreters of thought?

Whose household words are songs in many keys,

Sweeter than instrument of man e'er caught!

Whose habitations in the tree-tops even

Are half-way houses on the road to heaven!

Think every morning when the sun peeps through

The dim, leaf-latticed windows of the grove, How jubilant the happy birds renew

Their old, melodious madrigals of love!

And when you think of this, remember too

'Tis always morning somewhere, and above

The awakening continents, from shore to shore,

Somewhere the birds are singing evermore.

LONGFELLOW. "Birds of Killingworth." 




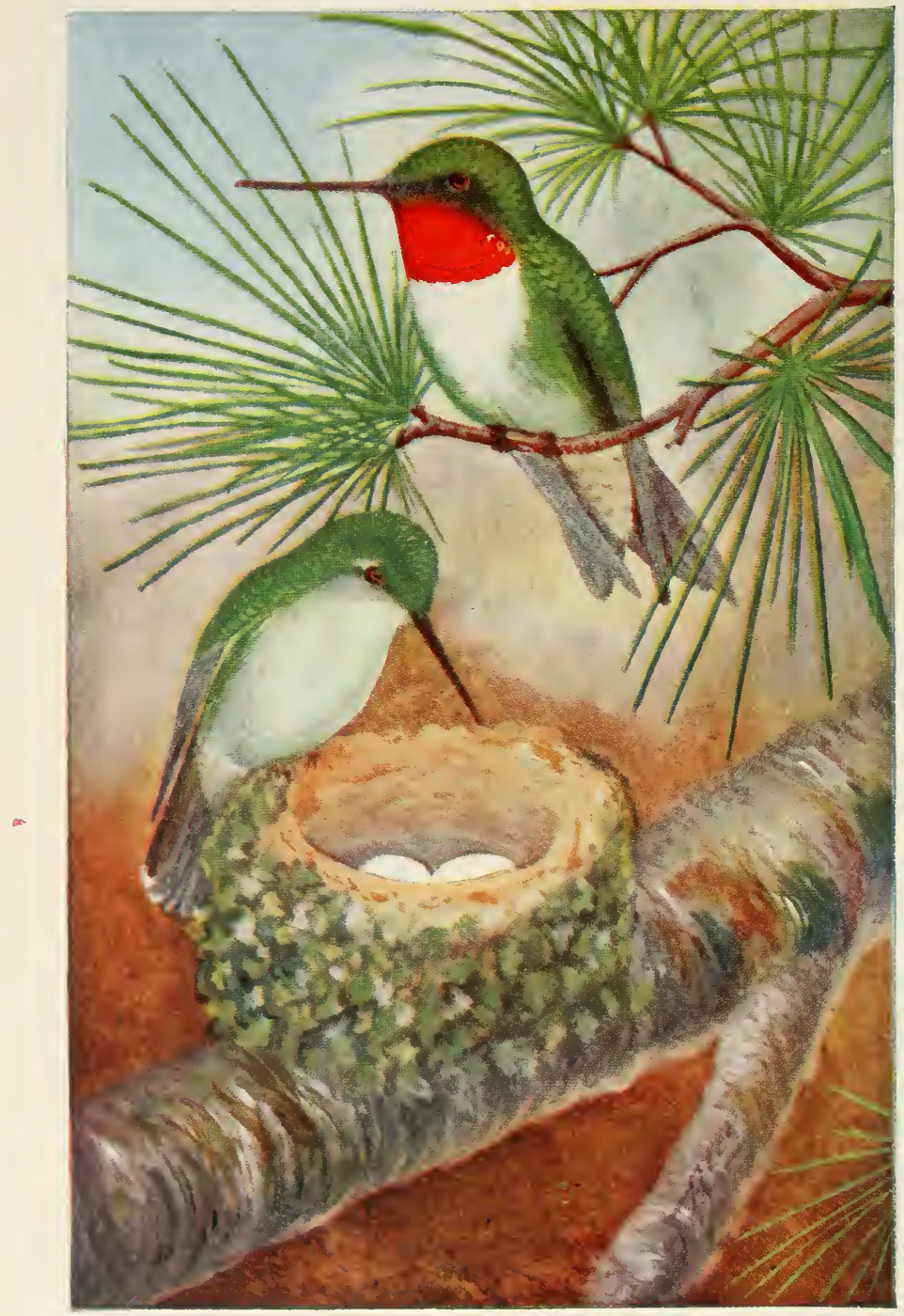




\title{
BIRDS IN LITERATURE
}

\author{
BY \\ ABBY P. CHURCHILL
}

STATE NORMAL SCHOOL

FITCHBURG, MASS.

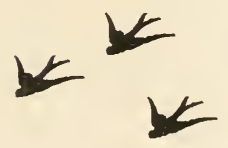

WORCESTER, MASS.

The Davis Press, Inc.

Printers and Publishers

1911 
COPYRIGHT, I905

BY ABBY P. ChURCHILL

COPYRIGHT, IIII

By The Davis PRess, INC.

SECOND EDITION 


\section{Introduction}

$\mathrm{E}$ see with what we are; and what we see is con-
stantly changing us for better or for worse. If we ugliness, we see ugliness, and our spiritual growth is abnormal and deformed. If we look for beauty, the beautiful meets us everywhere and transforms our minds and hearts.

The past decade has witnessed an almost unparalleled turning of men to Nature, seeking refreshment and renewal through her beauty and her mystery. Men have not always looked at Nature in this way, nor do all today. To primitive man she brought fear and awe and wonder. Many centuries must pass before a Wordsworth could declare "that Nature never did betray the heart that loved her." And yet from the very beginning men must have thought of the birds--particularly of those whose migrations were the most striking, and of the eagle and others that seemed in their soaring to touch the very heavens--as allied with clouds and winds and stars very closely to the mysterious unseen and unknown. So in the earliest attempts at literature we find the birds, often in simple reference or figure, often in myth or legend. In the literature of all races we find them and in the literature of all times.

The compiler of this book, an enthusiastic, intelligent lover and student of Nature, one who understands the meaning of Nature as a resource in life, one who has spent many years helping others to see, to feel, and to know the beauty and the mystery of the flowers, the birds, the woods and the fields, has brought together herein from those who have entered into and understood bird life the myths, legends and traditions; the pregnant thoughts from 
poets' minds; the appreciative descriptions and interpretations; that through these word pictures we all may see our common birds in beauty and in truth,

"For, don't you mark? We're made so that we love First when we see them painted, things we have passed Perhaps a hundred times nor cared to see."

This is just as true of the poet's word picture as it is of the canvas of Fra Lippo Lippi, and the collector of these bird pictures has rendered a service and met a need. This book will arouse and create an interest in birds, it will lighten the labor of all who attempt to lead others to appreciate and love our wonderful bird life. It is a growth in response to a need, and is published because of the constant demand for copies.

JOHN G. THOMPSON.

State Normal School,

Fitchburg, Massachusetts.

January, 1905. 


\section{Preface}

The cordial reception given this volume has exhausted the first edition. Believing that the work here recorded should be perpetuated and its influence extended, a second edition has been published. This edition has the added attractiveness of sixteen full color plates, by which the characteristics of as many birds may be observed. For the use of these plates the publishers are indebted to Mr. Charles K. Reed, Worcester, Mass., author and publisher of "Water Birds," "Land Birds," and other works.

The publication of this compilation has been made possible by the courtesy of those authors and publishers who have generously permitted the use of their copyrighted material.

The selections from the writings of Longfellow, Whittier, Emerson, Lowell, Holmes, Burroughs, Aldrich, Thoreau, Stedman, Celia Thaxter, Lucy Larcom, Frank Bolles, Bradford Torrey, Olive Thorne Miller, Florence Merriam, Trowbridge and Minot are used by permissoin of and special arrangement with Houghton Mifflin Company.

D. Appleton \& Co., Doubleday, Page \& Co., The Educational Publishing Co., Little, Brown \& Co., The J. P. Lippincott Co., Lothrop, Lee \& Shepard, Charles Scribner's Sons, Harper and Brothers, have allowed the use of extracts from the books mentioned in connection with their names in the bibliography, while Messrs. Eben E. Rexford and Ernest Thompson Seton have kindly consented to the use of those selections which bear their names. Such material of Dr. Charles Conrad Abbott and Mr. John Burroughs as is not controlled by publishers is used by the courtesy of these gentlemen. The compiler is also indebted to Messrs. H. R. Gibbs, John G. Thompson and Henry T. Bailey for valuable assistance.

AbBy P. Churchill.

Febroary, 1911. 



\section{The Origin of Birds}

Long ago, even before the time of birds in the world, say the Indians, God touched the earth wherever He wished a tree to appear, and there immediately a tree sprang up.

Then as now, when summer passed, autumn came. In the early fall, the leaves of the trees changed their green to colors of a brighter hue. The autumn winds came. The leaves in their play waved in the wind, fluttered about the branches, and at last fell to the ground.

God so loved the leaves He did not wish them to die, so He changed them to bird); giving to them wings and strength with which to fly. From the red-brown leaf of the oak came the robin. Ths leaves of the red maple changed to cardinal birds, the yellow willow leaves became little yellow birds, and the brown leaves flew away as sparrows and larks.

Because these first birds were once leaves of the forest, their descendants have always loved the trees and lived among them, finding food and shelter in their foliage and branches.

Adapted. 


\section{The Bloodless Sportsman}

I go a-gunning, but take no gun;

I fish without a pole;

And I bag good game, and catch such fish

As suit a sportsman's soul;

For the choicest game that the forest holds

And the best fish of the brook

Are never brought down with a rifle shot,

And are never caught with a hook.

I bob for fish by the forest brook,

I hunt for game in the trees,

For bigger birds than wing in the air,

Or fish that swim the seas.

A rodless Walton of the brooks,

A bloodless sportsman, I--

I hunt for the thoughts that throng the woods,

The dreams that haunt the sky.

The woods were made for the hunters of dreams,

The brooks for the fishers of song;

To the hunters who hunt for the gunless game

The streams and the woods belong.

There are thoughts that moan from the soul of the pine,

And thoughts in a flower bell curled;

And the thoughts that are blown with the scent of the fern

Are as new and as old as the world.

So, away! for the hunt in the fern-scented wood,

Till the going down of the sun;

There is plenty of game still left in the woods

For the hunter who has no gun.

So, away! for the fish by the moss-bordered brook

That flows through the velvety sod;

There are plenty of fish still left in the streams

For the angler who has no rod. SAm WaLter Foss. 


\section{Greetings}

Darlings of children and of bard, Perfect kinds by vice unmarred, All of worth and beauty set

Gems in Nature's cabinet;

These the fables she esteems Reality most like to dreams.

Welcome back, you little nations,

Far-travelled in the south plantations;

Bring your music and rhythmic flight,

Your colors for our eyes' delight:

Freely nestle in our roof,

Weave your chamber weatherproof;

And your enchanting manners bring

And your autumnal gathering.

Exchange in conclave general

Greetings kind to each and all,

Conscious each of duty done

And unstained as the sun.

EMERson.

What are the voices of birds-

Ay, and of beasts,--but words, our words,

Only so much more sweet?

BRownING.

The little Hiawatha

Learned of every bird its language,

Learned their names and all their secrets,

How they built their nests in summer,

Where they hid themselves in winter,

Talked with them whene'er he met them,

Called them Hiawatha's Chickens.

LONGFELLOW. 

$\mathrm{O}$, wad some Power the giftie gie us To see oursels as ithers see us!

Burns. 



\section{Birds in Literature}

\section{BITTERN, American}

Like the other members of its family, it excels in standing still, and will hold its head erect and motionless amid the tall grass till the watcher tires of looking and pronounces the suspicious object nothing but a stick after all. The bittern's fame rests upon its vocal performance, or "boom." This is sometimes exactly like the working of an old-fashioned wooden pump, and sometimes-even with the same bird-like the driving of a stake in a bog. The strange notes are delivered with equally strange contortions, as if the bird were horribly nauseated, and are preceded by a succession of quick snapping or gulping sounds-" hiccoughs," one observer has called them. No water is employed in the operation, in spite of the circumstantial assertions of several persons who profess to have seen the bird swallowing and then ejecting it.

Torrey. Chapman's Handbook of Birds. ${ }^{21}$

\section{BLACKBIRD, Crow}

$\mathrm{He}$ is one of the most brilliant of our bird beauties. Watch him as he ambles over the branches, and when the sunlight strikes him you will wonder who could have been so blind as to dub him blackbird. Call him, rather, the black opal. He is a bird of many accomplishments. To begin with, he does not condescend to hop, like ordinary birds, but imitates the crow in his stately walk; then he has a steering apparatus that the small boy might well 


\section{Blackbird, Crow}

study in coasting time. He can turn his tail into a rudder. . Moreover, he can pick beechnuts, catch crayfish without getting nipped, and fish for minnows alongside of any ten-year-old.

Florence A. Merriam. Birds Through an Opera Glass. ${ }^{2}$

As a songster it is a most dismal failure. All the ills that ever attacked a singer's larynx seem concentrated in its throat; yet, like many another supposititious and execrable vocalist, it persists in trying to sing. When a large number of them lift up their voices together, it certainly makes what someone has aptly called a good wheelbarrow chorus.

\section{Parkhurst. The Birds' Calendar. ${ }^{31}$}

There is evidently some music in the soul of this bird . . . though he makes a sad failure in getting it out. His voice always sounds as if he were laboring under a severe attack of influenza, though a large flock of them heard at a distance on a bright afternoon of early spring produce an effect not unpleasing. The air is filled with crackling, splintering, spurting, semi-musical sounds, which are like pepper and salt to the ear.

Burroughs. Wake Robin. ${ }^{1}$

In consequence of these depredations [on the maize crop], they are detested by the farmer as a pest to his industry . . . Up to the time of harvest I have uniformly, on dissection, found their food to consist of larvæ, 


\section{Blackbird, Crow}

caterpillars, moths, and beetles, of which they devour such numbers that but for this providential economy the whole crop of grain, in many places, would probably be destroyed by the time it began to germinate.

$$
\text { Nuttall's Ornithology. }{ }^{26}
$$

It is impossible to take this bird seriously, he is so irresistibly ludicrous. His manners always suggest to me the peculiar drollery of the negro, one of the old-fashioned sort as we read of him.

Olive Thorne Miller. A Bird-Lover in the West. ${ }^{4}$

The crow blackbirds cackled and jingled.

Burroughs.

The blackbirds make the maples ring With social cheer and jubilee.

EMERson.

The blackbirds clatt'rin' in tall trees, An' settlin' things in windy congresses.

LOWELL. 


\section{BLACKBIRD, Red-Winged}

When early in March the Red-wings come, then we know that the tide of the year has turned. With perennial faith in the season they come in flocks of hundreds, singing their springtime chorus with a spirit that March winds cannot subdue.

Chapman. Bird Life. ${ }^{22}$

In oozy pastures where a brook lazily finds its way through the farm is the ideal pleasure-ground of this "bird of society." His notes "h'-wa-ker-ee" or "con-quer-ee" are liquid in quality, suggesting the sweet, moist, cool retreats where he nests.

Neltje Blanchan. Bird Neighbors. ${ }^{23}$

Who is not conscious of a thrill of pleasure at sight of one of the handsome birds sailing down to a fence, with scarlet epaulettes fairly standing out on his shoulders? . . . The o-ka-lee of the Red-wing stirs associations whose richness is all their own.

Florence A. Merriam. Birds of Village and Field. ${ }^{1}$

"The red-wing flutes his o-ka-lee," and, fluting it, blots out all the disaster that winter has wrought. There is no early spring-tide note so full of summer; none that warms the landscape so much and tempers the March winds till they are softened to a zephyr.

Аввотт. Birds About Us. ${ }^{2 \pi}$ 


\section{Red-Winged Blackbird}

O gurgle-ee-e, o-gurgle-ee-e, some of the most liquid notes ever heard, as if produced by some of the water of the Pierian spring, flowing through a kind of musical water pipe, and at the same time setting in motion a multitude of fine vibrating metallic springs. Like a shepherd merely meditating most enrapturing glees on such a water pipe.

Thoreau. Spring. ${ }^{12}$

The red-wing flutes his o-ka-lee.

EMERSon.

\section{BLACKBIRD, Rusty}

They often indulge in a curious spluttering, squeaking, musical concert that one listens to with pleasure.

Neltje Blanchan. Bird Neighbors. ${ }^{23}$

They begin, as it were, by disgorging or spitting it out like so much tow, from a full throat, and conclude with a clear, fine, shrill, ear-piercing whistle.

Thoreau. Spring. ${ }^{12}$ 


\section{BLUEBIRD}

Although the bluebird did not come over in the Mayflower, it is said that when the Pilgrim Fathers came to New England this bird was one of the first whose gentle warblings attracted their notice, and, from its resemblance to the beloved Robin Redbreast of their native land, they called it the Blue Robin.

\section{Florence A. Merriam. Birds of Village and Field. ${ }^{1}$}

When Nature made the bluebird, she wished to propitiate both the sky and the earth, so she gave him the color of one on his back and the hue of the other on his breast, and ordained that his appearance in spring should denote that the strife and war between these two elements was at an end. He is the peace-harbinger; in him the celestial and terrestrial strike hands and are fast friends.

\section{Burroughs. Wake Robin. ${ }^{5}$}

If the king-bird is one of the chief sinners, the bluebird certainly ranks among the highest of the feathered saintsa Nathaniel indeed, in whom is no guile. Its mellow, coaxing love-note is one of the most affectionate sounds in nature, and matches the delicate gentleness of its ways, making it the favorite alike of poet and peasant.

Parkhurst. The Birds' Calendar. ${ }^{31}$ 


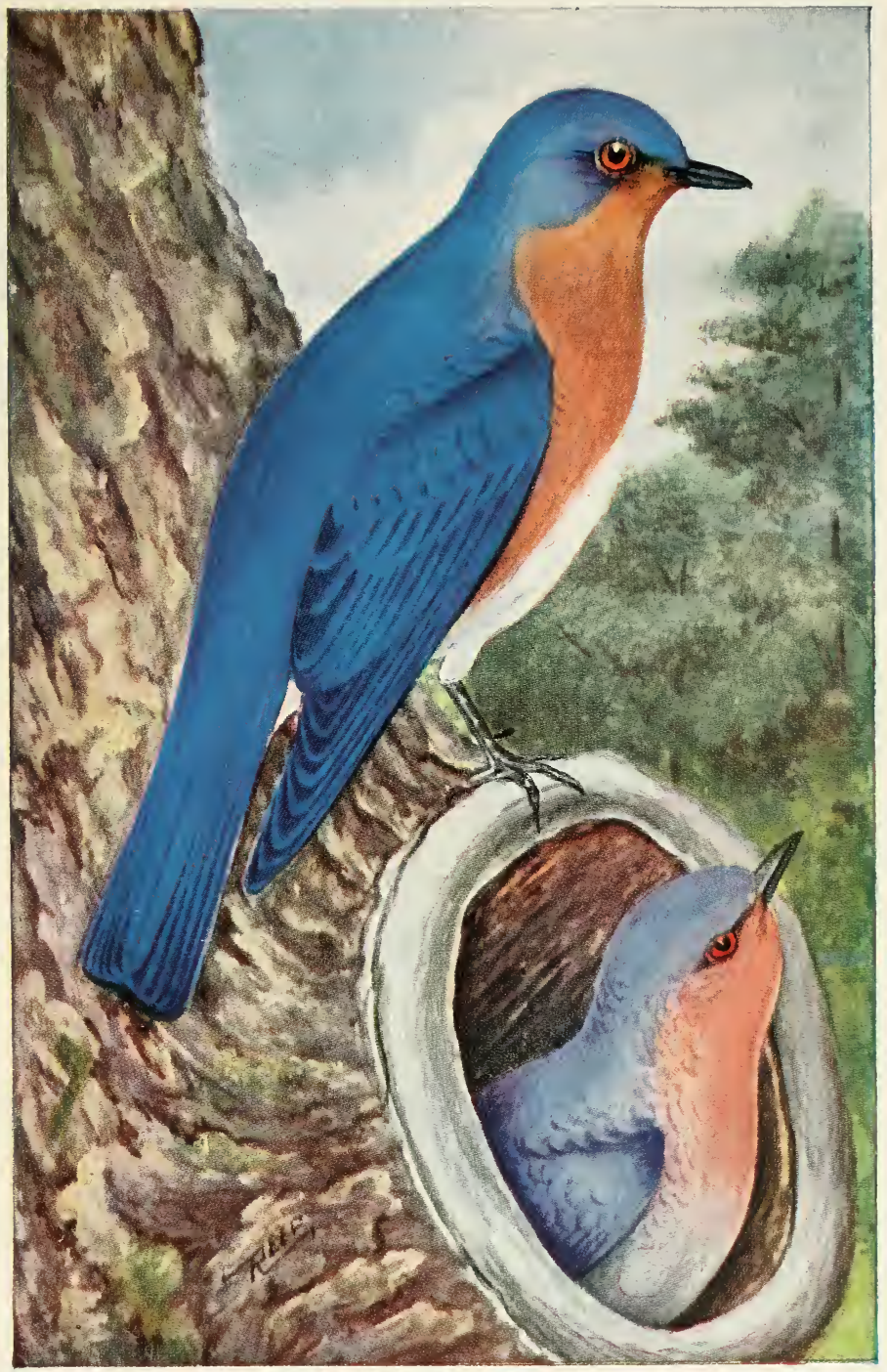





\section{Bluebird}

The bluebird comes, and with his warble drills the ice, and sets free the rivers and ponds and frozen ground.

\section{Thoreau. Spring. ${ }^{12}$}

Song: "The violet of sound."

The warble of this bird is innocent and celestial like its color.

Thoreau.

Their short rich warble curls through the air.

Thoreau.

"Dear! dear! think of it, think of it."

Purity, purity.

Burroughs.

Tru-al-ly, tru-al-ly.

BLanchan.

"Far-away, far-away." (in autumn.)

"Drearily, drearily." (in autumn.)

A bit of heaven itself

Winging, springing, always flinging, Flinging music all about him.

Harriet Prescott Spofford. 
Selected.

Sparrows far off, and nearer, April's bird, Blue-coated,--flying before from tree to tree,

Courageous sing a delicate overture

To lead the tardy concert of the year.

EMERson.

Hark! ' $\mathrm{T}$ is the bluebird's venturous strain High on the old fringed elm at the gateSweet-roiced, valiant on the swaying bough,

Alert, elate,

Dodging the fitful spits of snow,

New England's poet-laureate

Telling us Spring has come again.

T. B. AldRich.

The bluebird, shifting his light load of song From post to post along the cheerless fence, Was as a rhymer ere the poet came.

LOWELL.

\section{Bluebird}

This earliest May day herald, This prophet of the spring, Has brought celestial color

Upon his breezy wing.

Heaven loves to scatter earthward

Flakes of its own soft hue;

The first bird, the last blossom

Wear the same shade of blue.

Selected. 


\section{Bluebird}

\section{The Bluebird}

Listen a moment I pray you; what was the sound that I heard?

Wind in the budding branches, the ripple of brooks or a bird? Hear it again, above us! and see! a flutter of wings!

The bluebird knows it is April, and soars toward the sun and sings.

Never the song of the robin could make my heart so glad. When I hear the bluebird singing in spring, I forget to be sad. Hear it! a ripple of music! sunshine changed into song! It sets me thinking of summer when the days and their dreams are long.

Winged lute that we call a bluebird, you blend in a silver strain

The sound of the laughing waters, the patter of spring's sweet rain,

The voice of the winds, the sunshine, and fragrance of blossoming things.

Ah! you are an April poem, that God has dowered with wings!

E. E. REXFord. 
Bluebird

\section{The Bluebird's Song to the Flowers}

I know the song that the bluebird is singing, Out in the apple tree where he is swinging; Brave little fellow! the skies may be dreary, Nothing cares he while his heart is so cheery.

Hark! how the music leaps out from his throat! Hark! was there ever so merry a note?

Listen awhile and you'll hear what he's saying, Up in the apple tree swinging and swaying.

"Dear little blossoms, down under the snow, You must be weary of winter, I know; Hark! while I sing you a message of cheer, Summer is coming and springtime is here.

"Little white snowdrop, I pray you arise; Bright yellow crocus, come open your eyes; Sweet little violets, hid from the cold, Put on your mantles of yellow and gold! Daffodils, daffodils! say, do you hear? Summer is coming, and springtime is here!" 


\section{Bluebird}

\section{Bluebirds and Robins}

\section{AN INDIAN LEGEND.}

Wenonah, the motherless daughter of an Indian chief, loved nothing so well as the birds and beasts of the field. She was happy only when she was with them. Even the fiercest of the animals often carried their young to her that she might caress them.

Of all the birds she loved the robins and the bluebirds best, and, when, one spring morning just at day-dawn, she received a message to join her mother in the spirit-land, she asked these birds to accompany her part of the way that her departure might be unseen.

Before they set out, she took some moist clay and rubbed it on the breasts of the birds as a sign that they should return in safety to the earth. After a long flight the rays of the rising sun shone upon their breasts and turned them to a brick-red color. When Wenonah saw this she told them that they must turn back. The tender-hearted bluebirds began to weep. To comfort them, Wenonah stroked their backs, and their feathers, with the touch of her fingers, became as blue as the sky above them. The birds all begged to go on with her to her journey's end, but she knew that this would be impossible. So she bade them farewell and requested them to wear forever on their breasts, in remembrance of her, the red color which had come upon them while doing her this last loving service.

To this day both the robins and the bluebirds have kept their red breasts, and the bluebirds still have their blue backs and sad note, and if the young do at first wear the old-time spots they quickly moult away.

AdAPTED. 


\section{BOBOLINK. REED BIRD. RICE BIRD}

A handsome, gifted, and striking individual, renowned in prose and poetry as a most dashing, happy-go-lucky sort of fellow, a feathered extravaganza, an intoxicated soloist, an artistic comedian.

\section{Parkhurst. The Birds' Calendar. ${ }^{31}$}

I cannot look upon him as ever in a very serious humor. He seems to be a lively, jocular little fellow, who is always jesting and bantering; and when half a dozen different individuals are sporting about in the same orchard, I can imagine they might represent the persons dramatized in some comic opera. . . . . In the grand concert of Nature it is the bobolink that performs the recitative, which he delivers with the utmost fluency and rapidity, and we must listen carefully not to lose many of his words.

FlaGG. A Year With the Birds. ${ }^{25}$

The most exuberantly happy of all our birds, he seems to contain the essence of summer joy and sunshine. "Bobolinkum-linkum-deah-deah-deah" he warbles away, the notes fairly tumbling over each other as they pour out of his throat.

Florence A. Merriam. Birds Through an Opera Glass. ${ }^{2}$

It is as if he touched his harp within a vase of liquid melody and when he lifted it out the notes fell like bubbles from the trembling strings.

Thoreau. Walden. ${ }^{16}$ 


\section{Bobolink. Reed Bird. Rcei Bird}

Instead of the light-colored shirt and vest and decorous dark coat sanctioned by the Worth of conventional bird circles for centuries, this radical decks himself out in a jet-black shirt and vest, with not so much as a white collar to redeem him; besides having all of four almost white patches on the back of his coat!

Florence A. Merriam. Birds Through an Opera Glass. ${ }^{2}$

When the bobolinks go south they stop on the way, first in the marshes, where they are known as "Reedbirds," and then in the rice-fields of South Carolina and Georgia, where they are known as "Rice-birds."

Florence A. Merriam. Birds of Village and Field. ${ }^{1}$

He turns lightly about and breaks out with a song precisely analogous to a burst of gay and self-satisfied laughter, as much as to say, "Ha! ha! ha! I must have my fun, Miss Silverthimble, thimble, thimble, if I break every heart in the meadow, see, see, see!"

Burroughs. Birds and Poets. ${ }^{10}$

From time to time during a long period of years I have added an occasional note or two to my singular vocabulary caught from this meadow doggerel. . . . Here is the list copied from my random notes.

“'Bob-o- link o' love o' lucky o' linkum o' linkum a jingle a jingle a ditty bob for bonny Missus Linkum see see keep an eye up here my sweet see see hear me tinkle 


\section{Bobolink. Reed Bird. Rice Bird}

tinkle sprinkle such a liquid mellow glee wet your whistle bob temperance $\mathrm{O}$ gush a gurgle scatter spatter such a carol as she alone can follow follow pipe it pipe it bob $\mathrm{O}$ tintinnabulate for temperance temperance whink a seeble seeble here I go across the clover sprink a jinkle sprinkle treble burst a bubble purl a babble gabble glee shake it out upon the meadow chink a link a wheedle see look'eelook'ee ninkum ninkum deacon yonder see yessir yessir funny fellow he whew whew but I must seek a rest for my cap is coming off and I can hardly keep my jacket on whew temperance"

Gibson. Starlight and Sunshine. ${ }^{33}$

Gladness of woods, skies, waters, all in one, The bobolink has come, and, like the soul

Of the sweet season vocal in a bird,

Gurgles in ecstasy we know not what

Save June! Dear June! Now God be praised for June.

LOWELL.

June's bridesman, poet o' the year,

Gladness on wings, the bobolink, is here;

Half-hid in tip-top apple blooms he swings,

Or climbs aginst the breeze with quiver' in wings,

Or, givin' way to 't in a mock despair,

Runs down, a brook o' laughter, thru the air.

LOWELL.

Why, I'd give more for one live bobolink

Than a square mile o' larks in printer's ink.

LOWELL. 


\section{Bobolink. Reed Bird. Rice Bird}

The crack-brained bobolink courts his crazy mate

Poised on a bulrush tipsy with his weight.

Holmes.

When Nature had made all her birds,

With no more cares to think on,

She gave a rippling laugh and out

There flew a Bobolinkon. C. P. Cranch.

One day in the bluest of summer weather,

Sketching under a whispering oak,

I heard five bobolinks laughing together

Over some ornithological joke.

C. P. Cranch.

When little Teddy heard a merry bobolink,

He said, "Mamma, that bird is laughing, I should think."

Still rang the wondrous song,

So varied, clear and strong,

And listening Teddy cried,

"Why, I should think he tied a lot of songs together."

Selected.

Out in the clover, blowing free,

As the white clouds roll away,

In a mad-cap ripple of ecstasy,

He's pouring his merry lay.

'Neath the blue of the peaceful summer skies,

Where the bees round the flowers throng,

His wake, as over the field he flies,

Is a bubbling trail of song.

O bobolinkum, by fancy led,

What a happy fate to wing

O'er the sea of clover, billowy red,

With nothing to do but sing.

E. E. Rexford. 


\section{Robert of Lincoln}

Merrily swinging on brier and weed, Near to the nest of his little dame, Over the mountain-side or mead,

Robert of Lincoln is telling his name:

Bob-o'-link, bob-o'-link,

Spink, spank, spink;

Snug and safe is that nest of ours, Hidden among the summer flowers.

Chee, chee, chee.

Robert of Lincoln is gaily drest,

Wearing a bright black wedding-coat;

White are his shoulders and white his crest.

Hear him call in his merry note:

Bob-o'-link, bob-o'-link, Spink, spank, spink;

Look, what a nice new coat is mine,

Sure there was never a bird so fine.

Chee, chee, chee.

Robert of Lincoln's Quaker wife,

Pretty and quiet, with plain brown wings,

Passing at home a patient life,

Broods in the grass while her husband sings:

Bob-o'-link, bob-o'-link,

Spink, spank, spink;

Brood, kind creature; you need not fear

Thieves and robbers while I am here.

Chee, chee, chee. 


\section{Bobolink. Reed Bird. Rice Bird}

Modest and shy as a nun is she;

One weak chirp is her only note.

Braggart and prince of braggarts is he,

Pouring boasts from his little throat:

$$
\begin{aligned}
& \text { Bob-o'-link, bob-o'-link, } \\
& \text { Spink, spank, spink; }
\end{aligned}
$$

Never was I afraid of man;

Catch me, cowardly knaves, if you can!

Chee, chee, chee.

Six white eggs on a bed of hay,

Flecked with purple, a pretty sight!

There as the mother sits all day,

Robert is singing with all his might:

Bob-o'-link, bob-o'-link,

Spink, spank, spink;

Nice good wife, that never goes out, Keeping house while I frolic about.

Chee, chee, chee.

Soon as the little ones chip the shell,

Six wide mouths are open for food;

Robert of Lincoln bestirs him well,

Gathering seeds for the hungry brood.

Bob-o'-link, bob-o'-link,

Spink, spank, spink;

This new life is likely to be

Hard for a gay young fellow like me.

Chee, chee, chee. 


\section{Bobolink. Reed Bird. Rice Bird}

Robert of Lincoln at length is made

Sober with work, and silent with care;

Off is his holiday garment laid,

Half forgotten that merry air:

Bob-o'-link, bob-o'-link,

Spink, spank, spink;

Nobody knows but my mate and I

Where our nest and our nestlings lie.

Chee, chee, chee.

Summer wanes; the children are grown;

Fun and frolic no more he knows;

Robert of Lincoln's a humdrum crone;

Off he flies, and we sing as he goes:

Bob-o'-link, bob-o'-link,

Spink, spank, spink.

When you can pipe that merry old strain, Robert of Lincoln, come back again.

Chee, chee, chee.

BRYANT.

\section{The O'Lincoln Family}

A flock of singing bircls were sporting in the grove; Some were warbling cheerily and some were making love. There were Bobolincon, Wadolincon, Winterseeble, Conquedle-

A livelier set were never led by tabor, pipe, or fiddle:Crying, "Phew, shew, Wadolincon; see, see Bobolincon Down among the tickle-tops, hiding in the buttercups;

I know the saucy chap; I see his shining cap

Bobbing in the clover there,-see, see, see!' 


\section{Bobolink. Reed Bird. Rice Bird}

Up flies Bobolincon, perching on an apple tree; Startled by his rival's song, quickened by his raillery. Soon he spies the rogue afloat, curvetting in the air, And merrily he turns about and warns him to beware!

" 'Tis you that would a wooing go, down among the rushes $\mathrm{O}$ ! Wait a week, till flowers are cheery; wait a week, and ere you marry,

Be sure of a house wherein to tarry;

Wadolink, Whiskodink, Tom Denny, wait, wait, wait!"

Every one's a funny fellow; every one's a little mellow;

Follow, follow, follow, follow, o'er the hill and in the hollow.

Merrily, merrily there they hie; now they rise and now they fly; They cross and turn, and in and out, and down the middle and wheel about,

With a "Phew, shew, Wadolincon; listen to me, Bobolincon! Happy's the wooing that's speedily doing,

That's merry and over with the bloom of the clover;

Bobolincon, Wadolincon, Winsterseeble, follow, follow me!"

O what a happy life they lead, over the hill and in the mead! How they sing, and how they play! See, they fly away, away! Now they gambol o'er the clearing,-off again, and then appearing:;

Poised aloft on quivering wing, now they soar, and now they sing,

"We must all be merry and moving; we must all be happy and loving;

For when midsummer is come, and the grain has ripened its ear, The haymakers scatter our young, and we mourn for the rest of the year;

Then, Bobolincon, Wadolincon, Winterseeble, haste, haste away!"

WiLson FlaGg. 


\section{BUNTING, SNOW. SNOWFLAKE}

They are the true spirits of the snow-storm. They are the animated beings that ride upon it and have their life in it.

Thoreau. Winter. ${ }^{15}$

These birds seem to be at their happiest in a storm, and whenever one comes their way they join in its whirl and scurry just for the fun of its fierce revelry, birds and flakes mingling in the same wild dance.

Florence A. Merriam. Birds of Village and Field. ${ }^{1}$

With a uniformity of movement which would put to shame the evolutions of the best-drilled troops, they whirl over the snow-clad fields, wheeling to right or left, as though governed by a single impulse. Suddenly they swing downward into a weedy field, alighting on the snow or ground, where they run-not hop about-like little beach birds.

Chapman. Bird Life. ${ }^{22}$

Their white forms seen against the intense blue give the impression of large snowflakes drifting across the sky.

Burroughs. Pepacton. ${ }^{9}$

When they rise all together, their note is like the rattling of nuts in a bag, as if the whole bin-full were rolled from side to side.

Thoreau. Autumn. ${ }^{14}$ 


\section{Bunting, Snow. Snowflake}

In its plumage it reflects the winter landscape,-an expanse of white surmounted or streaked with gray or brown; a field of snow with a line of woods or a tinge of stubble.

Burroughs. Birds and Poets. ${ }^{10}$

These are the true winter birds for you, these winged snowballs.

Thoreau. Winter. ${ }^{15}$

\section{BUTCHER-BIRD. NORTHERN SHRIKE}

Not even a hawk himself can produce the consternation among a flock of sparrows that the harsh, rasping voice of the butcher-bird creates. . . . Every shrike either impales or else hangs up, as a butcher does his meat, more little birds of many kinds, field-mice, grasshoppers, and other large insects than it can hope to devour in a week of bloody orgies. Field-mice are perhaps its favorite diet but even snakes are not disdained.

Neltje Blanchan. Bird Neighbors. ${ }^{23}$

The shrike has a hawk's bill but a sparrow's foot, and, lacking the powerful talons that make so deadly a weapon, he captures his prey with his strong mandibles. Possibly it may be due to his comparatively weak feet that he pursues the singular custom of impaling his prey on some thorn or hanging it from a crotch where he can better dissect it.

Chapman. Bird Life. ${ }^{22}$ 


\section{Butcher-Bird. Northern Shrike}

Perched on a point of vantage on some tree-top or weather-vane, his hawk-like eye can detect a grasshopper going through the grass fifty yards away.

Neltje Blanchan. Bird Neighbors. ${ }^{23}$

My attention was first called to it by hearing a harsh, uncouth noise, as unmusical as the creaking of a hinge, which it somewhat resembled, but with a venomous touch of animosity. I never heard anything more barbaric from the throat of any bird.

\section{Parkhurst. The Birds' Calendar. ${ }^{31}$}

In Germany he is called the nine-killer, from the belief that he kills and sticks upon thorns nine grasshoppers a day.

Burroughs. Locusts and Wild Honey. ${ }^{6}$

\section{CATBIRD}

It is unfortunate that the catbird's name should have originated in his call-note rather than in his song. The former is a petulant, whining, nasal tchay, to me one of the most disagreeable sounds in Nature, and so unlike the bird's song that he seems possessed of a dual personality. The catbird's song, from a musical standpoint, is excelled by that of few of our birds. His voice is full and rich, his execution and phrasing are faultless.

Chapman. Bird Life. ${ }^{22}$ 


\section{Catbird}

The catbird is unmistakably a Bohemian. He is exquisitely formed, and has a beautiful slate-gray coat, set off by his black head and tail. By nature he is peculiarly graceful, and when he chooses can pass for the most polished of the Philistine aristocracy. But he cares nothing for all this. With lazy self-indulgence he sits by the hour with relaxed muscles, and listlessly drooping wings and tail. If he were a man you feel confident that he would sit in shirt-sleeves at home and go on the street without a collar.

Florence A. Merriam. Birds Through an Opera Glass. ${ }^{2}$

He is the veriest "Dr. Jekyll and Mr. Hyde" of birds. Exquisitely proportioned, with finely-poised black head and satin-gray coat, which he bathes most carefully and prunes and prinks by the hour, he appears from his toilet a Beau Brummell, an aristocratic-looking, even dandified neighbor. Suddenly, as if shot, he drops head and tail and assumes the most hang-dog air, without the least sign of self-respect; then crouches and lengthens into a roll, head forward and tail straightened, till he looks like a little, short gray snake, lank and limp. Anon, with a jerk and a sprint, every muscle tense, tail erect, eyes snapping, he darts into the air intent upon some well-planned mischief. It is impossible to describe his various attitudes and moods.

Neltje Blanchan. Bird Neighbors. ${ }^{23}$

The catbird mother is one of the most anxious and devoted. If her nest is discovered, she exhibits so much distress that one sympathetic to bird griefs has no heart to pursue investigations. 


\section{Catbird}

The catbird is generous and helpful to others of his kind in trouble of any sort, feeding and caring for deserted or orphaned young ones of any species, and always ready to aid distracted parents in the defense of their homes and little ones.

Olive Thorne Miller. Chapman's Handbook of Birds. ${ }^{21}$

Ambitious of song, practising and rehearsing in private, she yet seems the least sincere and genuine of the sylvan minstrels, as if she had taken up music only to be in fashion, or not to be outdone by the robins and thrushes. In other words she seems to sing from some outward motive, and not from inward joyousness. She is a good versifier but not a great poet. Vigorous, rapid, copious, not without fine touches, but destitute of any high, serene melody, her performance . . . always implies a spectator. There is a certain air and polish about her strain, however, . . . that commands respect.

\section{Burroughs. Wake Robin. ${ }^{5}$}

\section{The Pussy-Cat Bird}

To-day when the sun shone just after the shower, A song bubbled up from the lilac-tree bower, That changed of a sudden to quavers so queer, For a moment I thought something wrong in my ear, Then I called little Dempster and asked if he heard. "Oh, yes," he replied; "it's the pussy-cat bird." 


\section{Catbird}

The pussy-cat bird has the blackest of bills, With which she makes all of her trebles and trills:

She can mimic a robin or sing like a wren, And I truly believe she can cluck like a hen; And sometimes you dream that her song is a word. Then quickly again-she's a pussy-cat bird.

The pussy-cat bird wears a gown like a nun, But she's chirk as a squirrel and chock-full of fun, She lives in a house upon Evergreen Lane,A snug little house, although modest and plain; And never a puss that was happier purred Than the feathered and winged little pussy-cat bird.

Clinton Scollard.

\section{The Cat-Bird}

Through the night and through the day

Runs a babbling brook away, 'Neath the hill and to the river Through the pasture, on forever. Shadowy playmates still I see, Rivalling the brooklet's glee; And the cat-bird's voice I hear, That so piqued my childhood's ear.

Saucy, mocking cat-bird

On the alder spray,

Even now I hear thee, Though so far away. 
Thou incarnate, wicked joy,

How I watched thee as a boy,-

Mocking with thy saucy call

Robin, jay, kingfisher, all,-

Picking up the varied notes

As they fell from feathery throats,

Screeching as in demon glee

Our astonishment to see!

Ashen-coated cat-bird

On the alder spray,

Mocking all thy fellows

Through the live-long day.

Thou highwayman of the wood,

Our New England Robin Hood,

Eating eggs thou did'st not lay,

Making other nests thy prey,

How with childish wrath we heard

Tales of thee, thou wicked bird,-

Of feathered maidens in distress,-

Longing still to make redress;-

But thou, saucy cat-bird,

On the alder spray,

All our maledictions

Mocked and jeered away!

Oft amid the leaves descried,

With thy pert head cocked one side, Oddly jerking thy long tail,

How I've heard thee jeer and rail, Scolding on through all the weathers, Like a Carlyle dressed in feathers; 
Then to mock the mockery,

Thou would'st bubble o'er in glee.

O thou cynic cat-bird, Mimicking mankind, All our whims and fancies Laughing down the wind.

Tragic, comic actor thou, For thy stage an alder bough; Now, some borrowed joyous note Pouring from thy feigning throat; Now, from wailing puss in sorrow Her alarm cry thou dost borrow; Till, to us bewildered, seems Each but fancies of our dreams.

Mimic actor, cat-bird, Thus thy betters do, Till 'tween good and evil Nothing seemeth true.

Cat-bird, but I love thee still, By the brook-side, 'neath the hill, Laughing, mocking in the trees, Feathered Mephistopheles; Playing out thy varied part, Mirroring the human heart; Fretting, scolding, scornful, then Bursting out, in joy, again!

Good and evil cat-bird

On the alder spray, Like thy contradictions Run our lives away. 


\section{CHAT, YELLOW-BREASTED}

If classification were based on character, the chat would surely be placed in a family by itself. . . . . If you will conceal yourself near his home, you may see him deliver part of his repertoire while on the wing, with legs dangling, wings and tail flapping, and his whole appearance suggesting that of a bird who has had an unfortunate encounter with a charge of shot.

Chapman. Bird Life. ${ }^{22}$

Now he barks like a puppy, then quacks like a duck, then rattles like a kingfisher, then squalls like a fox, then caws like a crow, then mews like a cat . . C C-r-r-r-r-rwhrr,-that's it,-chee,-quack, cluck-,yit-yit-yit,-now hit it,-tr-r-r-r,-when, caw, caw,-cut, cut,-tea-boy,who, who,-mew, mew.

Burroughs. Wake Robin. ${ }^{5}$

This is surely the clown among birds. . . . . He has the habit of singing . . . on moonlight nights.

Neltje Blanchan. Bird Neighbors. ${ }^{23}$

\section{CEDAR-BIRD. CEDAR WAXWING}

"The prince of feathered beaux."

These birds are singularly geritle and refined; soft of voice as they are of color, their plumage suggesting a fine Japanese water-color painting on silk, with its beautiful sheen and exquisitely blended tints.

Neltje Blanchan. Bird Neighbors. ${ }^{23}$ 


\section{Cedar-Bird. Cedar Waxwing}

They are birds of remarkable affection and intelligence, and their habits are peculiarly interesting. By lowering and raising their crests they gain great variety of expression, and when about the nest often assume protective attitudes, drawing themselves up to look like long-necked bottles or sticks of wood, and sitting absolutely motionless till one would imagine further endurance impossible.

Florence Merriam. Birds of Village and Field. ${ }^{1}$

These birds have even adopted the human symbol of tenderness, and are often seen kissing each other.

Florence A. Merriam. Birds Through an Opera Glass. ${ }^{2}$

Dr. Brewer says of this species as proof of their devotion to one another and their offspring: "Once when one had been taken in a net spread over strawberries, its mate refused to leave it, suffered itself to be taken in the hand in its anxiety to free its mate, and when set at liberty, would not leave until its mate had also been released and permitted to go with it."

FlagG. A Year With the Birds. ${ }^{25}$

He has no song or call, uttering only a fine bead-like note on taking flight. This note is the cedar-berry rendered back in sound. . . . B But in lieu of music, what a pretty compensation are those minute, almost artificiallike plumes of orange and vermilion that tip the ends of the primaries! Nature could not give him these and a song too.

Burroughs. Locusts and Wild Honey. ${ }^{6}$ 


\section{CHEBEC. LEAST FLYCATCHER}

The diminutive olive-pated gray sprite.

Neltue Blanchan. Bird Neighbors. ${ }^{23}$

$\mathrm{He}$ is a fearless little warrior, snapping his bill ominously as he charges full tilt at his enemy. . . . . in coat and habit a miniature of the phoebe and wood pewee, jerking not only his tail but his whole body with his emphatic call.

Florence A. Merriam. Birds Through an Opera Glass. ${ }^{2}$

Instead of the simple melody we might expect to hear from this modest bird, he salutes us with a singularly inappropriate, business-like chebéc, chebéc, varying the performance by murderous sallies after passing insects. In crescendo passages, he literally rises to the occasion, and on trembling wings sings an absurd "chebéc, tooralooral, chebéc, tooral-ooral," with an earnestness deserving better results.

Chapman. Handbook of Birds. ${ }^{21}$

\section{CHEWINK. TOWHEE. GROUND ROBIN}

There is a vigorousness about the towhee's notes and actions which suggests both a bustling, energetic disposition and a good constitution. He entirely dominates the thicket or bushy undergrowth in which he makes his home. The dead leaves fly before his attack. His white-tipped tail-feathers flash in the gloom of his haunts. He greets 


\section{Chewink. Towhee. Ground Robin}

all passers with a brisk inquiring chewink, towhee, and if you pause to reply, with a fluff-fluff of his short, rounded wings he flies to a near-by limb to better inspect you.

Chapman. Handbook of Birds. ${ }^{21}$

Song: Whip your chr-r-r-r-r.

Thoreau.

"Drink your te-he-he-he-he."

"If you pl-e-a-se."

\section{CHICKADEE. BLACK-CAPPED TITMOUSE}

What a blessing it would be if every one spoke his name as plainly as does this animated bunch of black and white feathers!

Chapman. Handbook of Birds. ${ }^{21}$

When you hear it, if you look carefully over the trees you will see a fluffy little body dressed out in a black hood whose sombre tone is relieved by whitish side pieces, a vest to match the sides of the hood, and a dark gray coat for contrast.

Florence A. Merriam. Birds Through an Opera Glass. ${ }^{2}$

Who can help loving a bird so courageous, "so frolic, stout, and self-possest"? Emerson did well to call him a scrap of valor.

Torrey. Every Day Birds. ${ }^{18}$ 


\section{Chickadee. Black-Capped Titmouse}

It fairly overflows with good spirits, and is never more contagiously gay than in a snow-storm.

\section{Neltje Blanchan. Bird Neighbors. ${ }^{23}$}

His jollity is absolutely contagious. The man that can listen to his rollicking outburst and not smile in sympathy, mark my words, that man is a villain. . . . . He presents a very practical claim upon our admiration in the fact that, from a series of careful observations once made at Paris, it has been estimated that a single specimen of this species, at the lowest computation, destroys annually two hundred thousand eggs alone of noxious insects.

\section{Parkhurst. The Birds' Calendar. ${ }^{31}$}

They are never silent. It is a matter of chick-a-dee-dee, or tsee-deet, or phe-bee, all the day long, the last of the three notes perhaps being a love-call.

Аввотт. Birds About Us. ${ }^{27}$

There is no sorrow in thy song,

No winter in thy year.

Emerson.

\section{The Titmouse}

You shall not be overbold

When you deal with Arctic cold,

As late I found my lukewarm blood

Chilled, wading in the snow-choked wood,

How should I fight? my foeman fine

Has million arms to one of mine: 


\section{The Titmouse}

East, west, for aid I looked in vain, East, west, north, south, are his domain. Miles off, three dangerous miles, is home; Must borrow his winds who there would come.

Up and away for life! be fleet!The frost-king ties my fumbling feet, Sings in my ears, my hands are stones, Curdles the blood to the marble bones, Tugs at the heart-strings, numbs the sense, And hems in life with narrowing fence. Well, in this broad bed lie and sleep,The punctual stars will vigil keep, Embalmed by purifying cold; The winds shall sing their dead-march old, The snow is no ignoble shroud, The moon thy mourner, and the cloud.

Softly,-but this way Fate was pointing, 'Twas coming fast to such anointing, When piped a tiny voice hard by, Gay and polite, a cheerful cry, Chic-chicadeedee! saucy note Out of sound heart and merry throat, As if it said, "Good day, good sir! Fine afternoon, old passenger! Happy to meet you in these places, Where January brings few faces."

This poet, though he live apart, Moved by his hospitable heart, Sped, when I passed his sylvan fort, To do the honors of his court, 


\section{The Titmouse}

As fits a feathered lord of land; Flew near, with soft wing grazed my hand, Hopped on the bough, then, darting low, Prints his small impress on the snow, Shows feats of his gymnastic play Head downward, clinging to the spray.

Here was this atom in full breath, Hurling defiance at vast death; This scrap of valor just for play Fronts the north-wind in waistcoat gray, As if to shame my weak behavior; I greeted loud my little savior, "You pet! what dost here? and what for?

In these woods, thy small Labrador, At this pinch, wee San Salvador! What fire burns in that little chest So frolic, stout and self-possest? Henceforth I wear no stripe but thine; Ashes and jet all hues outshine. Why are not diamonds black and gray, To ape thy dare-devil array? And I affirm, the spacious North Exists to draw thy virtue forth. I think no virtue goes with size; The reason of all cowardice Is, that men are overgrown, And, to be valiant, must come down To the titmouse dimension." 'Tis good-will makes intelligence, And I began to catch the sense 


\section{The Titmouse}

Of my bird's song: "Live out of doors

In the great woods, on prairie floors.

I dine in the sun; when he sinks in the sea,

I too have a hole in a hollow tree;

And I like less when Summer beats

With stifling beams on these retreats,

Than noontide twilights which snow makes

With tempest of the blinding flakes,

For well the soul, if stout within,

Can arm impregnably the skin;

And polar frost my frame defied,

Made of the air that blows outside."

With glad remembrance of my debt, I homeward turn; farewell, my pet! When here again thy pilgrim comes, He shall bring store of seeds and crumbs.

Doubt not, so long as earth has bread, Thou first and foremost shalt be fed; The Providence that is most large Takes hearts like thine in special charge, Helps who for their own need are strong, And the sky doats on cheerful song. Henceforth I prize thy wiry chant O'er all that mass and minster vaunt; For men mis-hear thy call in Spring, As 'twould accost some frivolous wing, Crying out of the hazel copse, Phe-be! And, in winter, Chic-a-dee-dee! I think old Cæsar must have heard In northern Gaul my dauntless bird And, echoed in some frosty wold, 


\section{The Titmouse}

Borrowed thy battle-numbers bold.

And I will write our annals new,

And thank thee for a better clew,

I, who dreamed not when I came here

To find the antidote of fear,

Now hear thee say in Roman key,

Paean! "Veni, vidi, vici".

EMERson.

\section{COWBIRD}

The cowbird takes its name from its habit of walking about among the cattle in the pasture, picking up the small insects which the cattle disturb in their grazing. The bird may often be seen within a foot or two of the nose of a cow or heifer, walking briskly about like a miniature hen, intently watching for its insect pray.

Blanchan. Bird Neighbors. ${ }^{23}$

The cowbird is an acknowledged villain, and has no standing in the bird world. English sparrows, either because they are not aware of the customs of New-World bird life, or because of a possible and not unlikely affinity, associate with him; but no self-respecting American bird will be found in his company. . . . . The females, lacking every moral and maternal instinct, leave their companions only long enough to deposit their eggs in the nests of other and smaller birds.

Chapman. Handbook of Birds. ${ }^{21}$ 


\section{Cowbird}

Some of the foster parents abandon their nests, or build a second nest over the eggs, but usually the milk of human kindness conquers, and the little bird does her best to bring up the foundling.

Florence A. Merriam. Birds of Village and Field. ${ }^{1}$

In the spring the male may be seen perched in an exposed position on a treetop, calling his long-drawn-out, glassy $k l u c k$, tse-e-e. Later, when wooing the female, he utters a curious, gurgling note, resembling the sound made by pouring water rapidly from a bottle, and accompanying it by motions which suggest extreme nausea.

Chapman. Bird Life. ${ }^{22}$

\section{CREEPER, BROWN}

The brown creeper's plumage is one of Nature's most successful feats of mimicry-an exact counterfeit in feathers of the brown-gray bark on which the bird lives.

Neltje Blanchan. Bird Neighbors. ${ }^{23}$

After watching him for several minutes one becomes impressed with the thought that he has lost the only thing in the world he ever cared for, and that his one object in life is to find it. Ignoring you completely, with scarcely a pause, he winds his way in a preoccupied, near-sighted manner up a tree trunk. Having finally reached the top of his spiral staircase, one might suppose he would rest long enough to survey his surroundings, but like a bit 


\section{Creeper, Brown}

of loosened bark he drops off to the base of the nearest tree and resumes his never-ending task.

Chapman. Handbook of Birds. ${ }^{21}$

If in the transmigration of souls, Sisyphus was ever incarnated in bird-form, we certainly have him here, neatly encased in feathers, for it is nothing but climb, climb, climb, and never getting there.

\section{PARkhurst. The Birds' Calendar. ${ }^{31}$}

The nest of the creeper is one to be searched for diligently, it is such an oddity in bird architecture. It is tucked in under a bit of loose bark on the side of a tree trunk, where it has a ready-made Mansard roof to keep off the rain, and a cosy home in all respects.

Florence A. Merriam. Birds of Village and Field. ${ }^{1}$

The song is described by Mr. Brewster as exquisitely pure and tender, alternately rising and falling and "dying away in an indescribably plaintive cadence, like the soft sigh of the wind among the pine boughs."

\section{CROSSBILL，RED}

As they swing about the pine trees, parrot-fashion, with the help of their bill, calling out $\operatorname{kim} p, \operatorname{kimp}$, that sounds like the snapping of the pine cones on a sunny day, it often seems easily possible to catch them with the hand. At first glance the birds would seem to be hampered by 


\section{Crossbill, Red}

their crossed beaks in getting at the seeds in the pine cones-a superficial criticism when the thoroughness and admirable dexterity of their work are better understood. They are said to be inordinately fond of salt.

Neltje Blanchan. Bird Neighbors. ${ }^{23}$

\section{The Legend of the Crossbill}

FROM THE GERMAN OF JULIUS MOSEN, BY LONGFELLOW.

On the cross the dying Saviour

Heavenward lifts His eyelids calm, Feels, but scarcely feels, a trembling

In His pierced and bleeding palm.

And by all the world forsaken,

Sees He how with zealous care

At the ruthless nail of iron

A little bird is striving there.

Stained with blood and never tiring,

With its beak it doth not cease,

From the cross t'would free the Saviour,

Its Creator's Son release.

And the Saviour speaks in mildness:

"Blest be thou of all the good!

Bear, as token of this moment, Marks of blood and holy rood!"

And that bird is called the crossbill,

Covered all with blood so clear,

In the groves of pine it singeth

Songs, like legends, strange to hear. 


\section{CROW, AMERICAN}

If we have an eye for the picturesque, we place a certain value upon the broad strong dash of color in the landscape, given by a flock of crows flapping their course above a corn-field, against an October sky.

Neltje Blanchan. Bird Neighbors. ${ }^{23}$

The crow is not without beauty. His coat of glossy black with voilet reflections, his dark eyes and sagacious expression of countenance, his stately and graceful gait, and his steady and equable flight, all give him a proud and dignified appearance.

\section{FlaGG. A Year With the Birds. ${ }^{25}$}

$\mathrm{He}$ is one of the drollest, most intelligent and individual of birds. His sedate walk, his gestures and conversation, proclaim him a bird of originality and reflection, who will repay our closest study.

Florence A. Merriam. Birds of Village and Field. ${ }^{1}$

In spite of the current opinion that the crow's calls are restricted to caw, he has an extended vocabulary. ... That he can converse fluently no one who has listened to him will question. Of the variants of caw, each with its own significance, there seems no end; but if you would be impressed with the crow's eloquence you must hear him when, in the fancied privacy of his own flock or family, he discusses the affairs of the day. His notes then are low, and so varied in tone that one cannot doubt their conversational character.

Chapman. Bird Life. ${ }^{22}$ 


\section{Crow, American}

That they do much damage in the corn-field is undeniable, but after the examination of nine hundred crows' stomachs, Dr. Merriam, of the Department of Agriculture, states that the amount of good done by the crow in destroying grasshoppers, May beetles, cut-worms, and other injurious insects, exceeds the loss caused by the destruction of corn. Moreover, if the corn be tarred before planting, the crows will not touch either the kernel or young sprout.

Chapman. Bird Life. ${ }^{22}$

Some farmers . . . take the trouble to feed the birds old corn during the time when they would be pulling up the young sprouts, for they realize that the workman is worthy of his hire, and would no more think of shooting crows than horses and cows because they demand grain in return for their work.

\section{Merriam. Birds of Village and Field. ${ }^{1}$}

There are times when I really believe they laugh. They are great talkers, so why should they not have a sense of humor?

Аввогт. Birdland Echoes. ${ }^{28}$

The crow is a useful bird in spite of the mischief of which it is guilty, and that is the sum and substance of the whole matter.

Аввотт. Birds About Us. ${ }^{2 \pi}$

Happy, hardy outlaws, the crows, how I love them! Alert, social, republican, always able to look out for themselves, not afraid of the cold and the snow, fishing when 


\section{Crow, American}

flesh is scarce, and stealing when other resources fail, the crow is a character I would not willingly miss from the landscape. $\mathrm{He}$ is the dusky embodiment of worldly wisdom and prudence.

Then he is one of Nature's self-appointed constables and greatly magnifies his office. He would fain arrest every hawk or owl or grimalkin that ventures abroad. I have known a posse of them to beset the fox and cry "Thief!" till Reynard hid himself for shame.

Burroughs. Winter Sunshine. ${ }^{8}$

Through the clear skies of March,

Blue to the topmost arch,

The crow, harsh-clamoring, sails.

Celia Thaxter.

Even the blackest of them all, the crow,

Renders good service as your man-at-arms,

Crushing the beetle in his coat-of-mail, And crying havoc on the slug and snail.

LONGFELLOW.

Oh, say, Jim Crow,

Why is it you always go

With a gloomy coat of black

The year long on your back?

Why don't you change its hue,

At least for a day or two,

To red or green or blue?

And why do you always wear

Such a sober, sombre air, 


\section{Crow, American}

As glum as the face of Care?

I wait for your reply,

And into the peaceful pause

There comes a curious, croaking cry-

"Oh, because! 'cause! 'cause!"

Clinton Scollard.

Iridescent is their plumage,

Loud their voices, bold their clamor,

In the pools and shallows wading;

Or in overflowing meadows

Searching for the waste of winter-

Scraps and berries freed by thawing.

Weird their notes, and hoarse their croaking;

Silent only when the night comes.

Bolles. Chocorua's Tenants. ${ }^{19}$

When the goldenrod uplifted

As a wayside benediction

Cheers the traveler on his journey

Through the sultry hours of August,

Deep within the forest's reaches,

In the shadow of the ledges,

Gather crows in friendly concourse

All their notes are low and drowsy, Muffled croaks, and guttural cawings, All their motions speak contentment, Tell of coolness, well-fed comfort.

Bolles. Chocorua's Tenants. ${ }^{19}$ 


\section{Why the Crow is Black}

In the days when the crow was as white as a swan, he could sing more sweetly than the nightingale. Now all the crows are black because of a malicious crow who made great mischief by telling tales.

This crow, a beautiful snow-white bird, lived in a cage in the house of his master Phœbus. Taught by Phœbus, he could counterfeit the speech of any man, and he could give an accurate account of anything he chanced to see.

Phœbus had a young wife whom he dearly loved. One day he went on a long journey. While he was away the crow carefully watched his mistress and listened to all that was said, so that he might have a long story for the ears of his master. Indeed such strange stories did he tell about the wife, that Phobus, who had a very hot temper, became so angry that he seized his bow and arrow and killed the poor woman.

Immediately after doing this fearful deed, he began to think how much he had always loved his wife, and, as he wept over her, his rage turned against the crow. Springing to his feet he caught the gossiping bird by the neck and shaking him until the snow-white feathers fell out, he cried, "O false thief, may you and your children forevermore be as black as the lies which you have told. May you never, through all your life, speak again! Instead of your sweet song, may you have naught but a dismal croak, in token that wherever you may go, always will follow the tempest and the rain!"

Then from the shelter of his house Phœbus threw the black crow out into the wide, wide world.

Adapted from "Canterbury Tales." 


\section{CUCKOO, BLACK-BILLED}

The cuckoos are among the first birds on Mr. Forbush's list of those that eat the caterpillars of the gypsy moth. Of the Black-billed's stomachs examined by the Biological Survey, sixteen contained three hundred and twenty-eight caterpillars, and in addition fifteen grasshoppers and some spiders.

Florence A. Merriam. Birds of Village and Field. ${ }^{1}$

Strange, reserved, unsocial bird,

Flitting, peering 'mid the leaves,

Thy lonely call a twofold word

Repeated like a soul that grieves,- -

"Kou-kou," "Kou-kou," a solemn plaint

Now loud and full, now far and faint.

"Kou-kou," "Kou-kou," repeated oft,

Like one who half recalls the chimes

Of "Cuckoo," "Cuckoo," in wood and croft

Across the seas in Wordsworth's times.

"Kou-kou," "Kou-kou," a cheerless strain

That to country folk forebodeth rain.

Burroughs.

\section{CUCKOO, YELLOW-BILLED}

Cuckoos have two toes directed forward and two backward, but the cause or use of this character it is difficult to understand. . . . C Cuckoos are mysterious birds well worth watching. I would not imply that their deeds are evil; on the contrary, they are exceedingly beneficial 


\section{Cuckoo, Yellow-Billed}

birds. . . . There is something about the cuckoo's actions which always suggests to me that he either has just done, or is about to do something he shouldn't.

Chapman. Bird Life. ${ }^{22}$

The cuckoos might well be called caterpillar birds, for they are so given to a diet of the hairy caterpillars that the walls of their stomachs are actually permeated with the hairs, and a section of stomach looks like the smoothly brushed top of a gentleman's beaver. . . . . . . .

\section{Merriam. Birds of Village and Field. ${ }^{1}$}

Neither cuckoo knows how to build a proper home; a bunch of sticks dropped carelessly into the bush, where the hapless babies that emerge from the greenish eggs will not have far to fall when they tumble out of bed, as they must inevitably do, may by courtesy only be called a nest.

Neltje Blanchan. Bird Neighbors. ${ }^{23}$

What do I hear?

Is it from far or near?

Is it upon the left or right,

From down below or from the height,

The sound of any living vocal thing?

Or is it only the vain conjuring

Of artist Fancy shaping large and clear

What dryads hear?

Selected. 



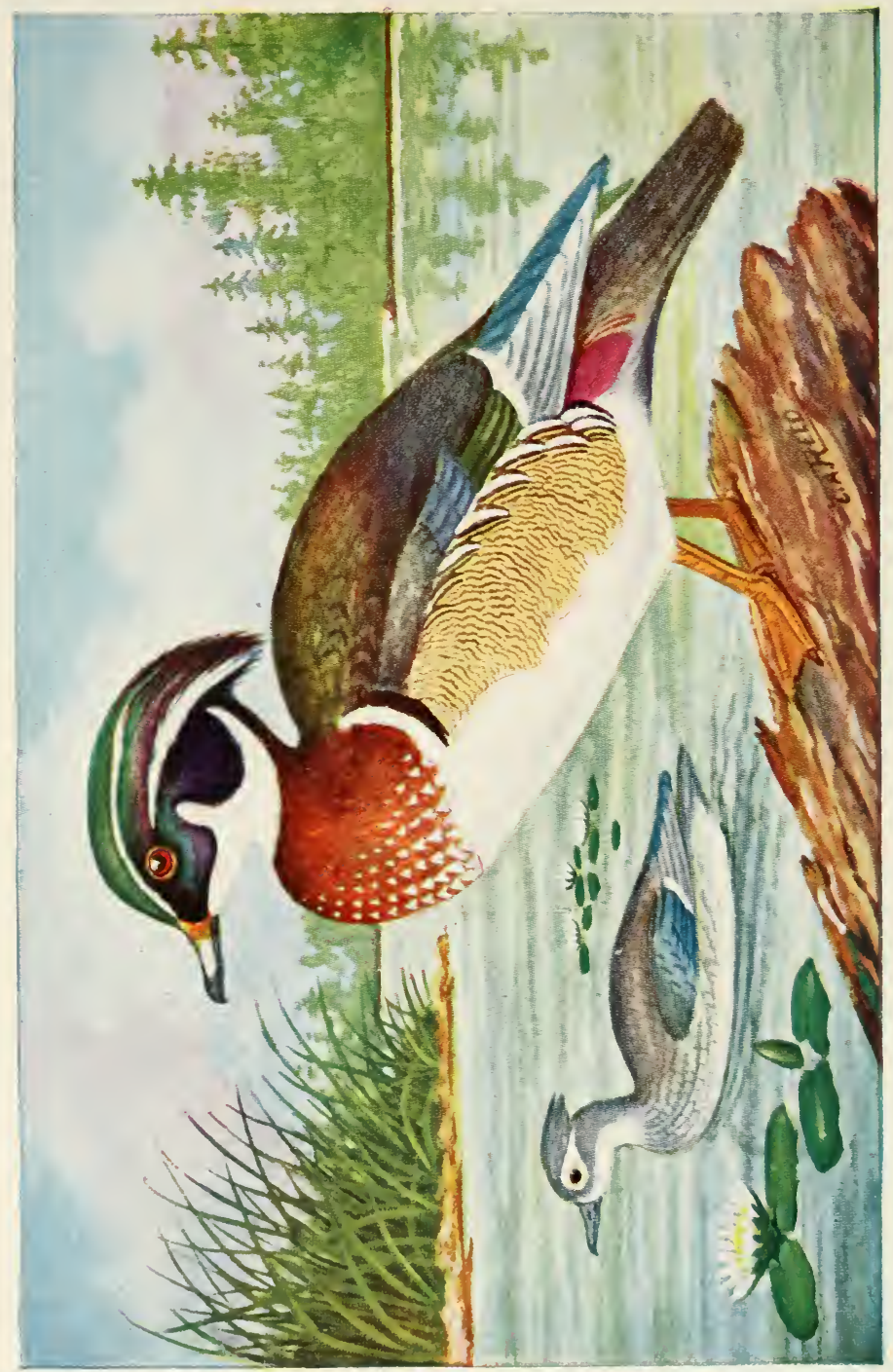




\section{DUCKS}

They are, for the most part, northern breeding birds and appear on our waters chiefly as migrants.

Chapman. Handbook of Birds. ${ }^{21}$

Ducks are by far the most beautiful of all aquatic birds in the colors of their plumage. . . . Their whistling flocks that pass frequently over our heads at different seasons always command our attention.

FLAGG. A Year With the Birds. ${ }^{25}$

\section{EAGLE, BALD}

Because immature birds reverse nature's order and are larger than adults, and their plumage undergoes three changes before they appear at the close of the third year in white heads and tails, some early writers described the black eagle, Washington's eagle, and the bald-headed eagle as three distinct birds. . . . . It is safe to say that any eagle seen in the eastern United States is the bald-head.

Emblem of the Republic, standing for freedom to enjoy life, liberty, and the pursuit of happiness, it must be owned that our national bird is a piratical parasite whenever he gets the chance.

Neltue Blanchan. Birds That Hunt and Are Hunted. ${ }^{24}$

They subsist principally upon fish. As a last resort they sometimes capture these themselves, but dead fish cast upon the shore are eagerly taken, and their habit of robbing the fish hawk of his well-earned booty is too well known to be commented upon.

Chapman. Handbook of Birds. ${ }^{21}$ 


\section{FINCH, PURPLE. PURPLE LINNET}

His color is peculiar, and looks as if it might have been imparted by dipping a brown bird in diluted poke-berry juice. Two or three more dippings would have made the purple complete.

Burroughs. Wake Robin. ${ }^{5}$

His song is a sweet flowing warble; music as natural as the rippling of a mountain brook.

Chapman. Bird Life. ${ }^{22}$

The caged linnet in the spring

Hearkens for the coral glee, When his fellows on the wing

Migrate from the Southern Sea.

EMerson.

\section{FLICKER. GOLDEN-WINGED WOODPECKER}

The golden-winged is a woodpecker of thirty-six aliases, annong which pigeon-woodpecker, yucker, high-hole, highholder, clape, and yellow-hammer are locally familiar.

A very ardent and ridiculous-looking lover is this bird, as, with tail stiffly spread, he sidles up to his desired mate and bows and bobs before her, then retreats and advances, bowing and bobbing again, very often with a rival lover beside him trying to outdo him in grace and general attractiveness.

Bianchan. Bird Neighbors. ${ }^{23}$ 


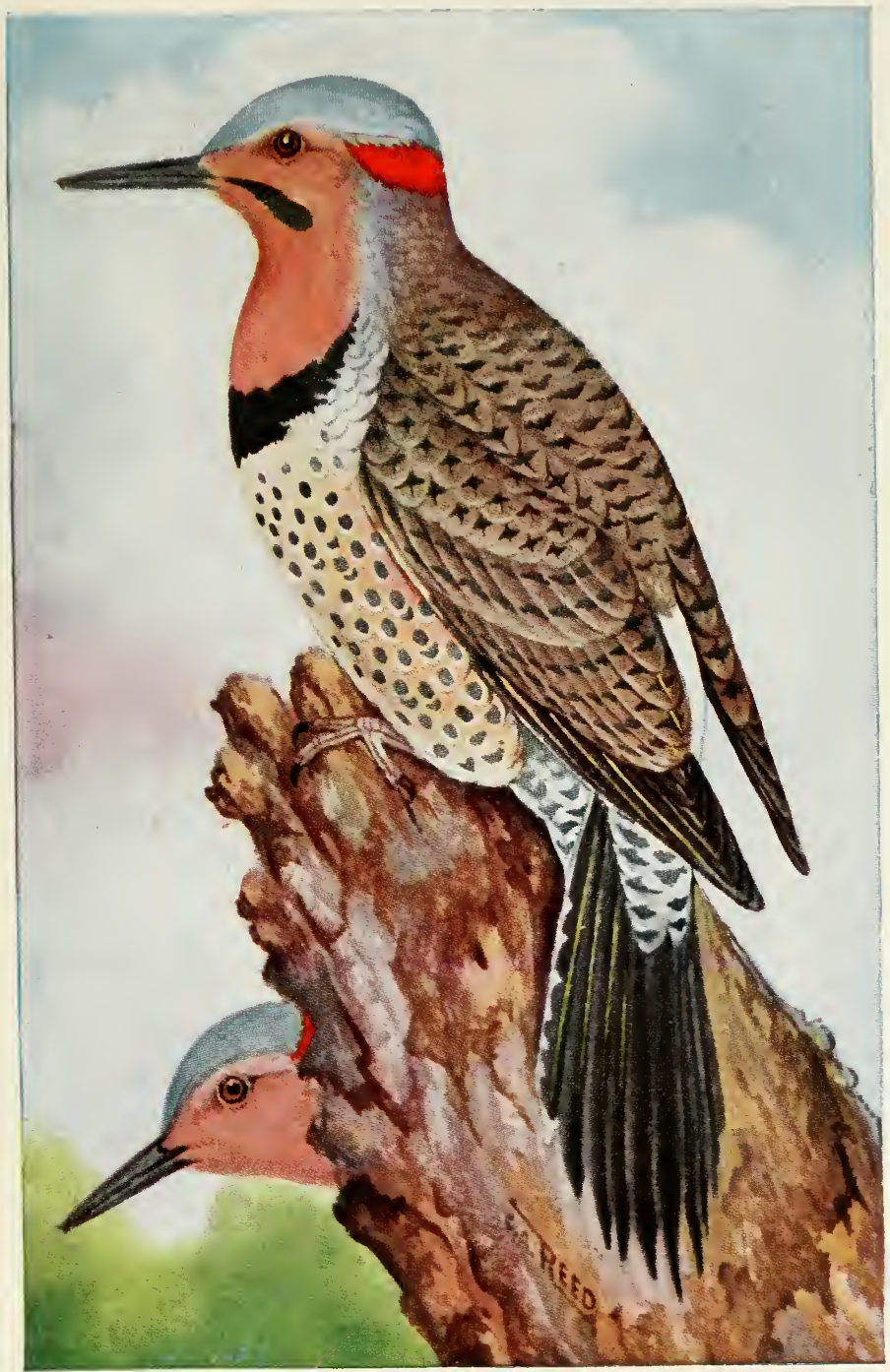





\section{Flicker. Golden-Winged Woodpecker}

A marked April note, proceeding sometimes from the meadows, but more frequently from the rough pastures and borders of the woods, is the call of the high-hole or golden-shafted woodpecker. . . . . It is a succession of short notes rapidly uttered, as if the bird said, "if-if-ifif-if-if-if." . . . . The high-hole is not so much a woodpecker as a ground-pecker. He subsists largely on ants and crickets, and does not appear till they are to be found.

Burroughs. Birds and Poets. ${ }^{10}$

How that single sound peoples and enriches all the woods and fields! They are no longer the same fields and woods that they were. This note really quickens what was dead. It seems to put life into the withered grass and bare twigs and henceforth the days shall not be as they have been. It is like the note of an alarm clock set last fall so as to wake nature up at exactly this date, $U p, u p, u p, u p, u p, u p, u p$.

\section{Thoreau. Spring. ${ }^{12}$}

Audubon describes its song as "a prolonged jovial laugh." Mrs. Wright gives it as "Wick, wick, wick, wick," and Dr. Abbott as "Wake-up, wake-up, wake-up."

His call-note is a vigorous nasal keè-yer.

\section{FLYCATCHER, GREAT-CRESTED}

The most dignified and handsomely dressed member of his family, the crested flycatcher has, nevertheless, an air of pensive melancholy about him when in repose that 


\section{Flycatcher, Great-Crested}

can be accounted for only by the pain he must feel every time he hears himself screech.

Neltje Blanchan. Bird Neighbors. ${ }^{23}$

His call, like an exclamation rings out above all other birds' notes. What! he seems to say, and, as though hearing something which not only surprised but amused him, follows this call with a chuckling whistle.

Chapman. Bird Life. ${ }^{22}$

An unexplained and not very winsome peculiarity of this bird is, that almost invariably its nest is, in part, composed of cast-off snake skins; doubtless for a good reason.

Parkhurst. The Birds' Calendar. ${ }^{31}$

Hardy and pugnacious, Colonel Goss says they fight fiercely for their mates, and have a habit of plucking the tail feathers of their rivals to disfigure them in the eyes of their lady loves.

Florence A. Merriam. Birds of Village and Field. ${ }^{1}$

Late in May he makes his nesting, Seeks a deep and darksome hollow

In the orchard's oldest tree-trunk, Lines it well with matted cow's hair

Grasses, feathers, bits of wasps' nest,

Slender roots, or silky fibres, Here and there a scrap of paper, Shred of bark, or seed of thistle. 


\section{Flycatcher, Great-Crested}

Odder things than these he uses,-

Things for something else than comfort;

Sometimes to the general tangle

He will add a tail of chipmunk,

Sometimes fish scales, iridescent,

Mingle in the mystic chaos,

But his chiefly favored fetish

Is a piece of cast-off snake skin.

Bolles. Chocorua's Tenants. ${ }^{19}$

\section{FLYCATCHER, OLIVE-SIDED}

The short necks of the flycatchers make their heads appear large for their bodies, a peculiarity slightly emphasized in this member of the family. . . . . A sharp, loud whistle, when-o-when-o-when-o, rings out from the throat of this olive-sided tyrant, warning all intruders off the premises; but however harshly he may treat the rest of the feathered world, he has only gentle devotion to offer his brooding mate.

\section{Neltje Blanchan. Bird Neighbors. ${ }^{23}$}

\section{GEESE, WILD}

We cannot well afford not to see the geese go over a single spring, and so commence our year regularly.

Thoreau. Spring. ${ }^{12}$ 


\section{Geese, Wild}

Geese sometimes fly in a straight line; but more frequently make a triangular figure, that permits each one . . . to see its leader. Some naturalists say that geese fly to a greater height than any other bird; others say they are surpassed by herons. They are often, however, at so great height that they may be heard, when nothing more of them than a black line can be seen.

FlaGg. A Year With the Birds. ${ }^{25}$

I suspect it will be found there is really some advantage in large birds of passage flying in the wedge form and cleaving their way through the air,-that they really do overcome its resistance best in this way, and perchance the direction and strength of the wind determine the comparative length of the two sides.

Thoreau. Spring. ${ }^{12}$

Far and high the wild geese cry,

"Spring! It is spring!"

Celia Thaxter.

Cloud-clearing geese to the lakes are a-steering.

Selected.

\section{GOLDFINCH. WILD CANARY. THISTLE-BIRD}

As pretty a sight as any garden offers is when a family of goldfinches alights on the top of a sunflower to feast upon the oily seeds-a perfect harmony of brown and gold.

Neltje Blanchan. Bird Neighbors. ${ }^{23}$ 


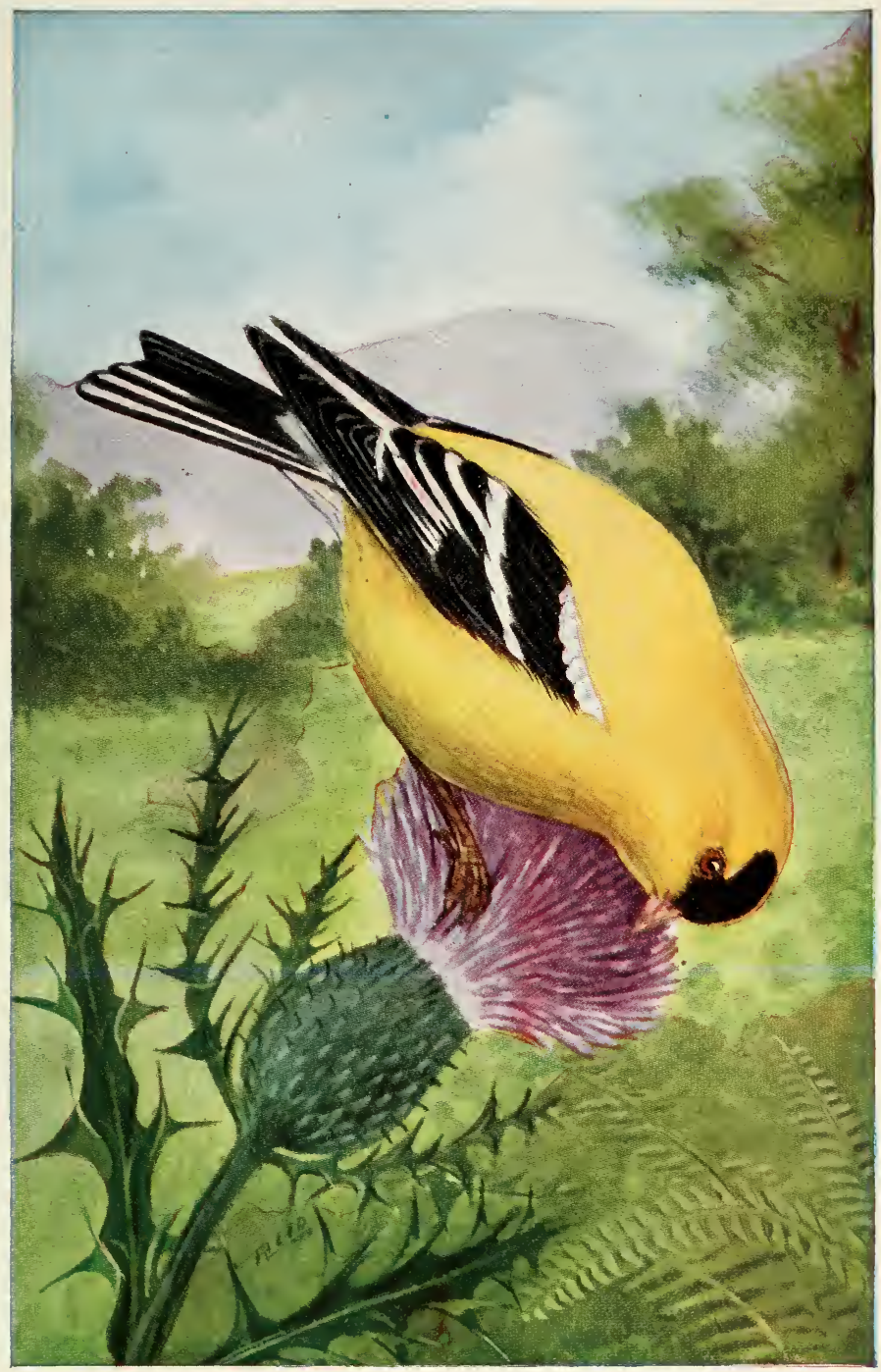





\section{Goldfinch. Wild Canary. Thistle-Bird}

His gentle ways and sweet disposition are never-failing antidotes for discontent. One cannot be long near a flock of these birds without being impressed by the refinement which seems to mark their every note and action.

Chapman. Bird Life. ${ }^{22}$

Among the commonest sounds in the country in late summer are the clusters of notes from the goldfinch in its wavy flight far overhead, one cluster in each undulation, and-to be precise-synchronizing with its wingvibrations, which occur in the last or rising half of each wave.

Parkhurst. The Birds' Calendar. ${ }^{31}$

Just listen to him some day as he flies away from his nest, singing over to himself in tones of exquisite love and tenderness his sweet bay-bee, bay-ee-bee.

Florence A. Merriam. Birds Through an Opera Glass. ${ }^{2}$

Their flight is expressive of their joyous nature, and as they bound through the air they hum a gay per-chic-oree, per-chic-o-ree.

Chapman. Handbook of Birds. ${ }^{21}$

Why this brief vision of golden filigree that seems suddenly flung across my fancy? What is the talisman? "I've cheated ye, per chick o pee, per chick o pee." What but the tiny goldfinch that has passed overhead in its looping flight, festooning the ether in glowing drapery of black and gold, each embroidered loop pinned with a wisp of song.

Gibson. Strolls by Starlight and Sunshine. ${ }^{33}$ 


\section{Goldfinch. Wild Canary. Thistle-Bird}

These birds do not shed their feathers in the spring, as careless observers are apt to think they do, but merely shed the outer webs of their feathers and quills, which peel off like a glove from the hand.

Burroughs. Riverby. ${ }^{11}$

A sweet-voiced goldfinch singing his soul away.

Olive Thorne Miller.

The goldfinch round the linden winds his song.

LUCY LARCOM.

\section{GROSBEAK, PINE}

At irregular intervals pine grosbeaks become abundant during the winter in New England, when, because of their size, they attract general attention. They usually resort to coniferous trees upon the seeds of which they feed, but they also eat berries and buds, and are said to be especially fond of the fruit of the staghorn sumach.

\section{Chapman. Bird Life. ${ }^{22}$}

The sight of a flock of these handsome, rosy-coated birds clustering around the cones of an evergreen is a picture to brighten many a dull day. . . . . T They are gentle birds, whose knowledge of man is so limited that they have no fear of him, and will often let themselves be taken in the hand.

Florence A. Merriam. Birds of Village and Field. ${ }^{1}$ 


\section{GROSBEAK, ROSE-BREASTED}

His back is disproportionately large and heavy, like a huge nose, which slightly mars his good looks; but Nature has made it up to him in a blush rose upon his breast, and the most delicate of pink linings to the under side of his wings.

Burroughs. Wake Robin. ${ }^{5}$

The farmers in Pennsylvania, who, with more truth than poetry, call this the potato-bug bird, are taking active measures to protect the neighbor that is more useful to their crops than all the insecticides known.

Neltje Blanchan. Bird Neighbors. ${ }^{23}$

Listen to the overflowing measure of its melody! How comparatively few the notes, and yet how telling! No single tone lost, no superficial intricacies. Sensuous, and suffused with color, it is like a rich, pulpy, luscious, pinkcheeked tropic fruit rendered into sound.

Gibson. Strolls by Starlight and Sunshine. ${ }^{33}$

There is an exquisite purity in the joyous carol of the grosbeak; his song tells of all the gladness of a May morning; I have heard few happier strains of bird music. With those who are deaf to its message of good cheer I can only sympathize, pitying the man whose heart does not leap with enthusiasm at the sight of rival males dashing through the woods like winged meteors, leaving in their wake a train of sparkling notes.

Chapman. Handbook of Birds. ${ }^{21}$ 


\section{Grosbeak, Rose-Breasted}

In addition to his song, the rose-breast has a short callnote, which sounds very much like the squeak of a pair of rusty shears.

\section{Torrey. Every Day Birds. ${ }^{18}$}

\section{GULL, AMERICAN HERRING}

High in the air, their pure white pinions clearly outlined against the deep blue, you can often see the gulls that are found along the coast. . . . . The pearly mantle that covers the back can only be seen as it now and then skims the surface of the water, or rests awhile on the waves from which it gathers its food. But the air seems their native element . . . . and in the grand sweep of their wings and in their slow and majestic progress they give to the beholder the sense of rest rather than weariness.

\section{Parkhurst. The Birds' Calendar. ${ }^{31}$}

The gull is distinguished by its small and lean body which is covered with a great quantity of feathers. Its wings and head are very large, all uniting to give the bird a false appearance of size. Hence, I suppose, originated the word, when used to imply deception. The sportsman who for the first time has shot one of these birds, expecting to find it large and plump, . . . . is said to be gulled.

\section{FLAGG. A Year With the Birds. ${ }^{25}$}

\section{HAWKS}

The red-shouldered and the red-tailed hawks are the birds to which the names chicken hawk and hen hawk 


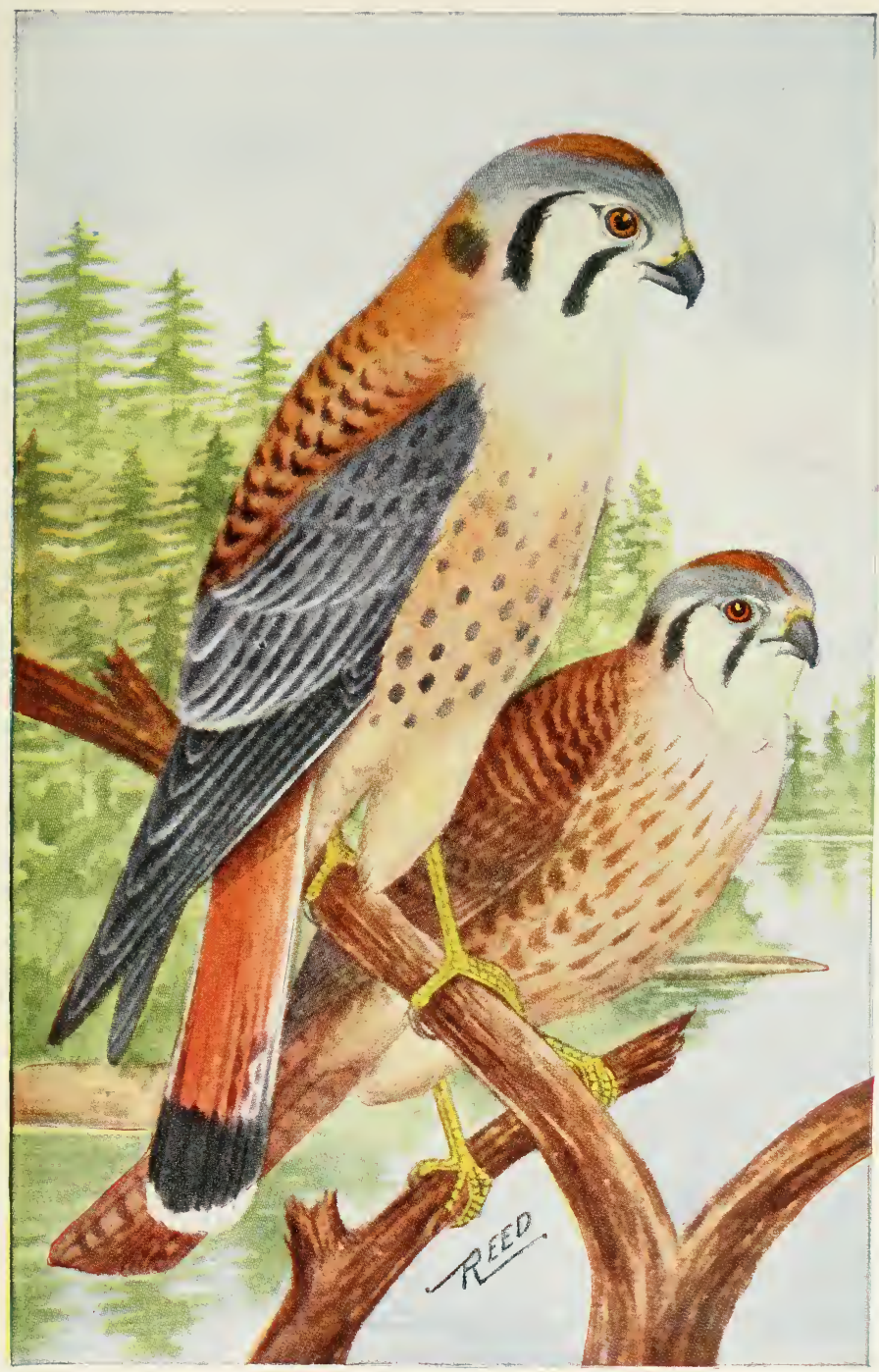





\section{Hawks}

are most frequently misapplied. Being both common species whose habits render them easily observed, they are often unjustly made to suffer for the sins of their birdkilling relatives of the genus Accipiter [sharp-shinned and Cooper's hawk].

\section{Chapman. Handbook of Birds. ${ }^{21}$}

It can be readily proved that it [the red-tailed hawk is far more beneficial than otherwise, and really deserves protection, instead of having a bounty placed on its head, as has been the case in several states. . . . . . Of two hundred and twenty stomachs of the red-shouldered hawk examined . . . . only three contained remains of poultry. . . . . So long as there is a grasshopper or a meadow mouse to eat, the sparrow hawk will let feathered prey alone; but these failing, it is a past-master in dropping like a thunder-bolt upon . . . . small birds found on the ground in thickets and the borders of woods. But it does not eat the farmer's broilers: the little sharpshinned and the Cooper's hawk attend to them.

Neltje Blanchan. Birds That Hunt and Are Hunted. ${ }^{24}$

Saw a large hawk circling over a pine wood. . . . Traveling ever by wider circles, what a symbol of the thoughts; now soaring, now descending, taking larger and larger circles, or smaller and smaller. It flies not directly whither it is bound, but advances by circles, like a courtier of the skies. . . . The poetry of motion, not as preferring one place to another, but enjoying each as long as possible, most gracefully thus surveying new scenes, and revisiting the old.

Thoreau. Autumn. ${ }^{14}$ 


\section{Hawks}

Silently overhead the hen-hawk sails

With watchful measuring eye, and for his quarry waits.

LOWELL.

\section{HERONS}

The heron is the impersonation of gloom, silence and solitude.

PARkhurst. The Birds' Calendar. ${ }^{31}$

No family of birds is possessed of more of those qualities which are especially regarded as picturesque than the herons. . . . . Their flying attitude, however, is uncouth, with their necks bent backwards, their heads resting against their shoulders, and their long legs stretched out behind them in the most awkward manner.

FLAGG. A Year With the Birds. ${ }^{25}$

\section{HUMMING BIRD, RUBY-THROATED}

The most exquisite gem in all the galaxy. An admirable creation from almost every point of view-as delicate as the cobweb that can cause its death, of such emotional intensity that even terror alone may quench its life, of ethereal mould and resplendent color, this tropical atom, is, notwithstanding, lion-hearted to attack even a man in defence of its nest. Valor and grace ne'er found a more unique companionship.

Parkhurst. The Birds' Calendar. ${ }^{31}$ 


\section{Humming Bird, Ruby-Throated}

It seems like the winged spirit of color . . . . its body like green beryl and its throat glancing fire.

Florence A. Merriam. Birds Through an Opera Glass. ${ }^{2}$

The nest is the most exquisite of all the beautiful structures of winged architects.

Florence A. Merriam. Birds of Village and Field. ${ }^{1}$

The nest contained two eggs about the size of a pea-bean.

FLAGG. A Year With the Birds. ${ }^{25}$

The ruby-throat feeds on insects as well as on the juices of flowers, and when you see him probing a corolla he is quite as likely to be after the one as the other.

Chapman. Bird Life. ${ }^{22}$

At evening one often hears of a "humming bird" going the rounds of the garden, but at this hour it is usually the sphinx-moth hovering about the flower-beds-the one other creature besides the bee for which the bird is ever mistaken. The postures and preferences of this beautiful large moth make the mistake a very natural one.

Neltje Blanchan. Bird Neighbors. ${ }^{23}$

The humming bird, with busy wing, In rainbow beauty moves.

Selected. 


\section{Humming Bird, Ruby-Throated}

With dizzy wings and dainty craft,

In green and gold, the humming-bird

Dashed here and there, and touched and quaffed

The honey-dew, then flashed and whirred,

And vanished like a feathered shaft

That glitters from a random bow.

J. G. Holland.

Minutest of the feathered kind,

Possessing every charm combin'd,

Nature, in forming thee, design'd

That thou should'st be

A proof within how little space

She can confine such perfect grace,

Rendering thy lovely fairy race

Beauty's epitome.

Thy burnished colors to bestow,

Her pencil in the heavenly bow

She dipp'd and made thy plumes to glow

With every hue.

Selected.

\section{INDIGO BIRD. INDIGO BUNTING}

I well remember watching one indigo-bird who, day after day, used to fly to the lowest limb of a high tree and sing his way up from branch to branch, bursting into jubilant song when he reached the topmost bough. I watched him climb as high into the air as he could, when, against a background of blue sky and rolling white clouds, the blessed little songster broke out into the blithest round that ever bubbled up from a glad heart.

Fi.orfince A. Merriam. Chapman's Handbook of Birds. ${ }^{21}$ 


\section{Indigo Bird. Indigo Bunting}

The "glowing indigo" of this tropical-looking visitor often seems the more intense by comparison with the blue sky, against which it stands out in relief as the bird perches singing in a tree-top. . . . . The noon-day heat of an August day that silences nearly every other voice, seems to give to the indigo-bird's only fresh animation. Neltje Blanchan. Bird Neighbors. ${ }^{23}$

\section{JAY, BLUE}

No bird of finer color or presence sojourns with us the year round than the blue jay. In a peculiar sense his is a case of "beauty covering a multitude of sins." . . . . Dishonest, cruel, inquisitive, murderous, voracious, villainous, are some of the epithets applied to this bird of exquisite plumage. Emerson, however, has said in his defence he does "more good than harm," alluding, no doubt, to his habit of burying nuts and hard seeds in the ground, so that many a waste place is clothed with trees and shrubs, thanks to his propensity and industry.

Neltue Blanchan. Bird Neighbors. ${ }^{23}$

What a handsome bird! . . . Not a hint of winter in his coloring! Note his purplish back as he bends over, the exquisite cobalt blue, touched off with black and white on his wings, and the black barring on the tightly closed tail he is bracing himself by. How distinguished his dark necklace and handsome blue crest make him look!

Florence A. Merriam. Birds Through an Opera Glass. ${ }^{2}$ 


\section{Blue Jay}

The blue jay is a true American. He is known throughout the continent, and never visits any other country.

FlaGG. A Year With the Birds. ${ }^{25}$

The jay is a relative of the crow, and has much of the crow's cleverness.

Torrey. Every Day Birds. ${ }^{18}$

The blue jay is both a mimic and a ventriloquist. Besides an inexhaustible stock of whistles and calls of his own, he imitates the notes of other species, notably those of the . . . hawks.

The blue jay, I fear, is a reprobate, but . . . . there is a dashing reckless air about him which makes us pardon his faults and like him in spite of ourselves.

Chapman. Handbook of Birds. ${ }^{21}$

I am always glad to hear his hearty call through the autumn woods; and the occasional sweet flute-like note he utters is one of the richest of our bird-notes, - a whole bird-concert squeezed into a single note that comes rolling down the narrow pathway through the woods.

Аввотт. Birds About Us. ${ }^{27}$

At times I have heard this bird utter a few notes like the tinkling of a bell, and which, if syllabled, might form such a word as dilly-lily.

FLAGG. A Year With the Birds. ${ }^{25}$ 


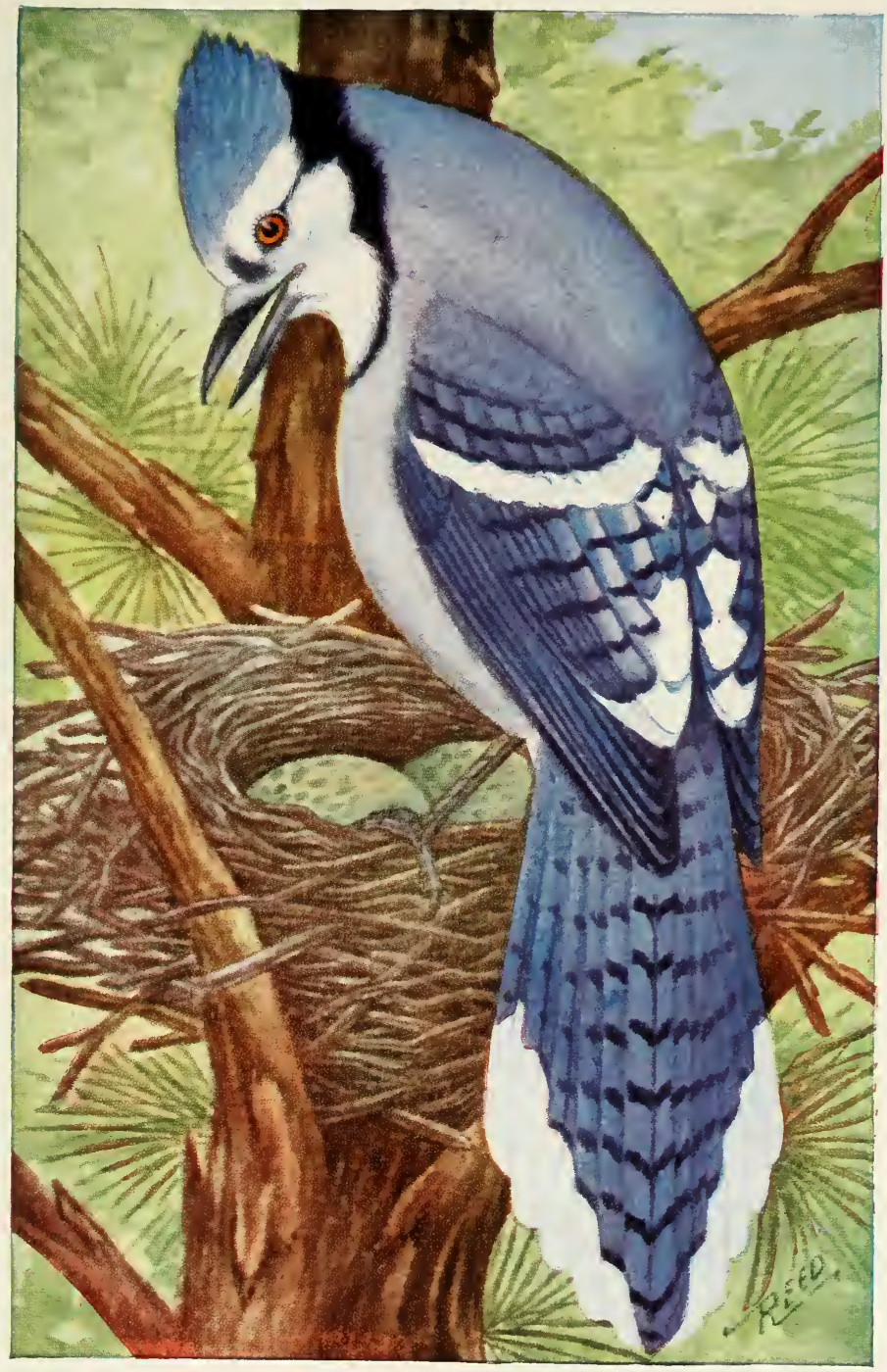





\section{Blue Jay}

His saucy crest seems to be kept in place by a band of black velvet ribbon passing under the chin.

Selected.

The blue jay blows the trumpet of winter.

Thoreau. Spring. ${ }^{12}$

The noisy jay comes with its startling cry,

'Mid yellow leaves of maple takes its perch;

A bit of blue in gold, as if the sky

Were seen in patches through the faded birch.

Selected.

Clad in blue with snow-white trimmings,

Clean and smooth in every feather,

Plumed and crested like a dandy,

Keen of vision, strong of muscle,

Shrewd in mimicry and dodging,

Knowing every copse and thicket,

Warm in snow and cool in summer,

Is the blue jay still a villain?

Outlawed by all bird tribunals,

As a wretch disguised, he's branded,

Shunned by every feathered creature;

Yet he prospers, man admires him.

Bolles. Chocorua's Tenants. ${ }^{19}$ 


\section{The Blue Jay}

O Blue Jay, up in the maple tree, Shaking your throat with such bursts of glee,

How did you happen to be so blue?

Did you steal a bit of the lake for your crest, And fasten blue violets into your vest?

Tell me, I pray you, tell me true!

Did you dip your wings into azure dye, When April began to paint the sky,

That was pale with the winter's stay?

Or were you hatched from a bluebell bright, 'Neath the warm gold breast of a sunbeam bright,

By the river, one blue spring day?

O Blue Jay, up in the maple tree, A-tossing your saucy head at me,

With ne'er a word at my questioning,

Pray cease for a moment your "tink-a-link," And hear when I tell you what I think,

You bonniest bit of spring.

I think when the fairies made the flowers

To grow in these merry fields of ours,

Periwinkles and voilets rare,

There was left of the spring's own color, blue,

Plenty to fashion a flower whose hue

Would be richer than all and as fair.

So putting their wits together, they

Made one great blossom so bright and gay

The lily beside it seemed blurred, And then they said, "We'll toss it in air.

So many blue blossoms grow everywhere,

Let this pretty one be a bird!"

Selected. 


\section{JUNCO. SLATE-COLORED SNOWBIRD}

Modest in manner and attire, there is nothing of especial interest in the junco's habits, and only bird-lovers can understand what a difference his presence makes in winter landscape. It brings a sense of companionship; it is a link between us and Nature. The bird's cheery twitter is as welcome as a ray of sunlight on a cloudy day.

Chapman. Bird Life. ${ }^{22}$

His suit of slaty gray, with its low-cut vest of white, is not worn by any other of our birds; and while some species show white outer tail-feathers in flight, the junco's seem to be more than usually conspicuous.

Chapman. Handbook of Birds. ${ }^{21}$

Little gray-robed monks and nuns.

Florence A. Merriam. Birds Through an Opera Glass. ${ }^{2}$

Peflecting the leaden skies above and the snow below. Parkhurst. The Birds' Calendar. ${ }^{31}$

\section{KINGBIRD. BEE-MARTIN}

He is sometimes called the tyrant, but the name is a libel. The kingbird is a fighter, but he is not a bully, and gives battle only in a just cause. His particular enemy is the crow, and during the nesting season each kingbird evidently draws an imaginary circle about his home within which no crow can venture unchallenged.

Chapman. Bird Life. ${ }^{22}$ 


\section{Kingbird. Bee-Martin}

It has an interesting and unusual method of bathing. Instead of standing in shallow water and dipping itself like other birds, it flies from its perch directly into the stream, dashing the water over its back, returning to its place and repeating the performance several times.

\section{Parkhurst. The Birds' Calendar. ${ }^{31}$}

Every country boy has laughed to see the kingbird chasing a crow. And a very lively and pleasing sight it is; the crow making for the nearest wood as fast as his wings will carry him, and one or two kingbirds in hot pursuit. Their great aim is to get above him and swoop down upon his back. Sometimes you see one actually alight upon a crow's back and, as boys say, "give it to him" in great style.

Another taking action of the kingbird is his trick of flying straight up in the air, almost perpendicularly, as if he were trying to see how near he could come to performing that impossible feat, and then tumbling about madly, with noisy outcries. Often it looks as if he actually turned somersaults. He cannot sing and so has to let his high spirits bubble over in these half-crazy gymnastics.

Torrey. Every Day Birds. ${ }^{18}$

He will often be seen hovering over a weed in a meadow, his fluttering wings supporting him so well that he seems to be hanging in air.

Florence A. Merriam. Birds of Village and Field. ${ }^{\text {I }}$ 


\section{Kingbird. Bee-Martin}

Bee-keepers accuse the kingbird of a taste for honeybees, but examination shows that the charge is unfounded. Only fourteen out of two hundred and eighteen stomachs contained remains of bees, most of which were drones, while sixty per cent. of the kingbird's food was found to consist of injurious insects.

Chapman. Handbook of Birds. ${ }^{21}$

\section{KINGFISHER, BELTED}

This bird is the celebrated Halcyon of the ancients, who attributed to it supernatural powers. It was supposed to construct its nest upon the waves, where it was made to float like a vessel at anchor. But as the turbulence of the storm would be likely to destroy it, Nature has gifted the sitting birds with the power of stilling the motion of the winds and waves during the period of incubation. The serene weather that accompanies the summer solstice was believed to be the enchanted effect of the benign influence of this family of birds. Hence the name Halcyon days was applied to this period of tranquillity. Some of the Asiatic nations still wear the skin of the kingfisher about their persons as a protection against moral and physical evils. The feathers are used as love-charms; and it is believed if the body of a kingfisher be evenly fixed upon a pivot, it will turn its head to the north like the magnetic needle.

FlaGG. A Year With the Birds. ${ }^{25}$ 


\section{Kingfisher, Belted}

$\mathrm{He}$ is the most marked of the trillers, having a loud, rapid call that Wilson compares to a watchman's rattle, and that, as Mr. Burroughs ingeniously suggests, reminds you of an alarm clock.

Florence A. Merrian. Birds Through an Opera Glass. ${ }^{2}$

The kingfisher is singularly grotesque in his appearance, though not without beauty of plumage.

FLAGG. A Year With the Birds. ${ }^{25}$

Though the king of fishermen, this sensible bird does not restrict himself to a diet of fish. In the east, if opportunity offers, he eats crustaceans, grasshoppers, crickets, and beetles of the June bug family.

Florence A. Merriam. Birds of Village and Field. ${ }^{1}$

Among the negroes in the south it is believed that if, in childhood, you go to the river at sunrise and see the minnows before the kingfisher does you will never die unless you are drowned, and that if you are drowned the kingfisher will carry your spirit directly to heaven.

Men say thy back received its coat of blue, From skies unclouded when the Flood was done, Then caught thy breast its gorgeous tawny hue In that long flight toward the setting sun.

SELeCted. 



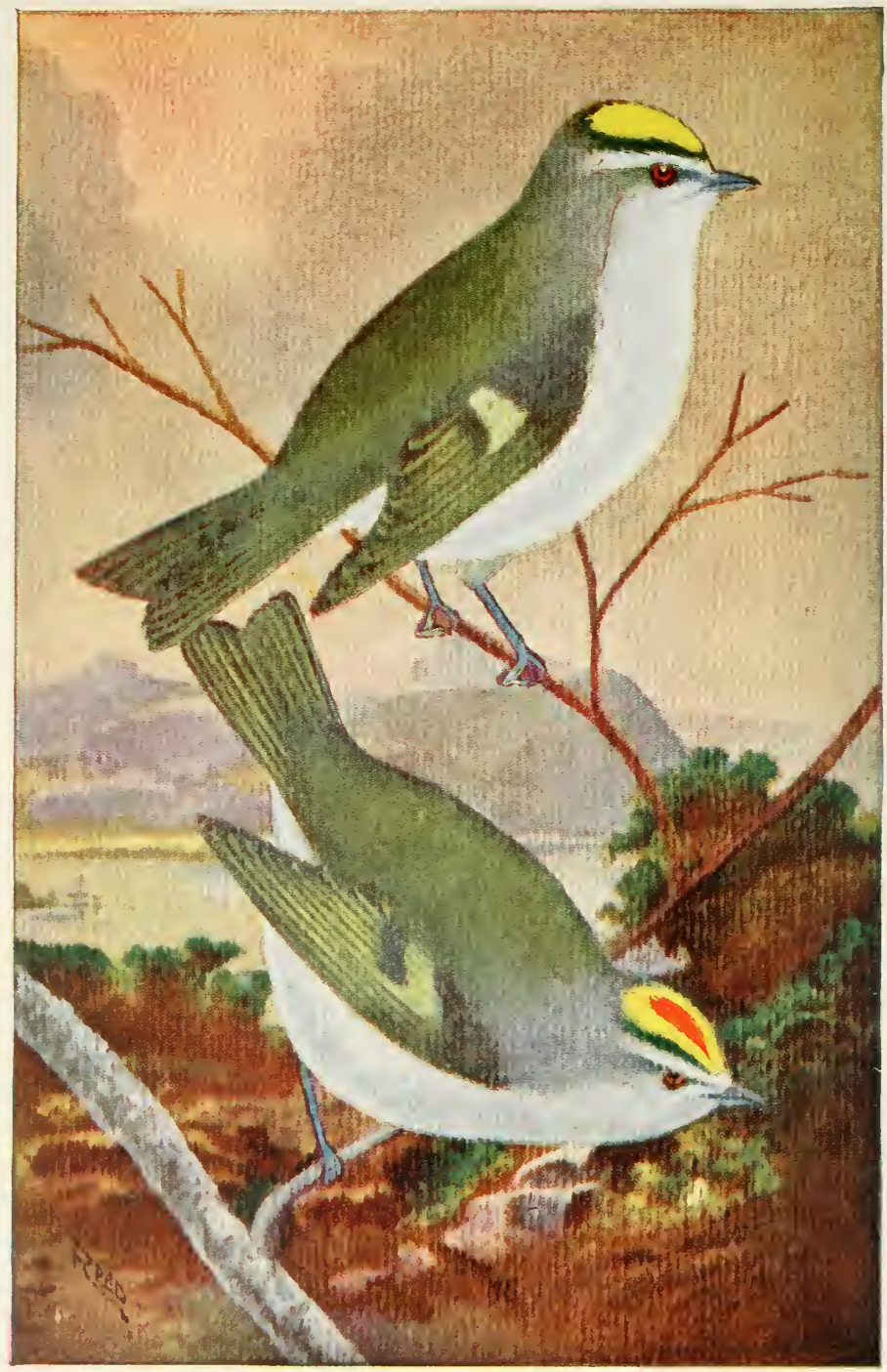




\section{KINGLET, GOLDEN-CROWNED}

Muffled in its thick coat of feathers, the diminutive goldcrest braves our severest winters, living evidence that, given an abundance of food, temperature is a secondary factor in a bird's existence.

Chapman. Handbook of Birds. ${ }^{21}$

$\mathrm{He}$ radiates an atmosphere of friendliness and good cheer which must be evident to any attentive observer.

Parkhurst. The Birds' Calendar. ${ }^{31}$

The nest is said to be extraordinarily large for so small a bird; but that need not surprise us when we learn that as many as ten creamy-white eggs . . . . is no uncommon number for the pensile cradle to hold. How do the tiny parents contrive to cover so many eggs and to feed such a nestful of fledglings?

Neltje Blanchan. Bird Neighbors. ${ }^{23}$

\section{KINGLET, RUBY-CROWNED}

They seem to be the feathered expression of perpetual motion. And how dainty and charming these dainty sprites are! They are not at all shy; you may approach them quite close if you will, for the birds are simply too intent on their business to be concerned with yours.

Neltje Blanchan. Bird Neighbors. ${ }^{23}$ 


\section{Kinglet, Ruby-Crowned}

The May morning when first I heard this kinglet's song is among the most memorable of my early ornithological experiences. . . . The song was mellow and flute-like, and loud enough to be heard several hundred yards; an intricate warble past imitation or description, and rendered so admirably that I never hear it now without an impulse to applaud. The bird is so small, the song so rich and full, that one is reminded of a chorister with the voice of an adult soprano. To extend the comparison, one watches this gifted but unconscious musician flitting about the trees with somewhat the feeling that one observes the choir-boy doffing his surplice and joining his comrades for a game of tag.

Chapman. Handbook of Birds. ${ }^{21}$

$\mathrm{He}$ is fairly to be esteemed a musical prodigy.

TORREY. Every Day Birds. ${ }^{18}$

\section{LARK, HORNED}

In America, the horned larks are alone in the family of which the famous skylark is one of the European members. While their song is wholly unpretentious, it is quaint and attractive, and is often given as the bird springs from the ground toward the sky, quite in the manner of the skylark.

Florence A. Merriam. Birds of Village and Field. ${ }^{1}$

In Greenland and Labrador, its summer home, it is a conspicuously handsome bird with its pinkish-gray and chocolate feathers, that have greatly faded into dull-browns when we see them in the late autumn.

Neltje Blanchan. Bird Neighbors. ${ }^{23}$ 


\section{LOON, BLACK-THROATED}

One of the most romantic of birds, the Hermit of our northern lakes, and so exceedingly shy that it is rarely seen except at a distance.

FlaGg. A Year With the Birds. ${ }^{25}$

Far out at sea in winter. . . I have often heard on a fine calm morning the sad and wolfish call of the solitary loon, which like a dismal echo seems slowly to invade the ear and, rising $\mathrm{as}^{\prime}$ it proceeds, dies away in the air. This boding sound to the mariner, supposed to be indicative of a storm, may be heard sometimes for two or three miles, when the bird itself is invisible or reduced almost to a speck in the distance. The aborigines, almost as superstitious as sailors, dislike to hear the cry of the loon, considering the bird, from its shy and extraordinary habits as a sort of supernatural being. By the Norwegians it is with more appearance of reason supposed to portend rain.

Nuttall's Ornithology. ${ }^{26}$

"He has also another rather soft and pleasing utterance, sounding like who-who-who-who, the syllables being so rapidly pronounced as to sound almost like a shake of the voice-a sort of weird laughter." To this Longfellow refers in his "Birds of Passage."

... . The loon that laughs and flies

Down to those reflected skies. 


\section{Legend of the Loon}

There is an old story, one which certainly has the appearance of truth, to the effect that when Nature manufactured the first loon she forgot to give him any legs at all, and that he had started off on the wing before she noticed her mistake. Then she picked up the first pair that came to hand and threw them after him. Unfortunately they were a misfit; and, what was perhaps still worse, they struck his body in the wrong place. They were not only too short, but they were so far aft that, although he could stand almost as straight as a man, and could swim like a fish, it was almost impossible for him to walk. When he had to travel on land, which he always avoided as far as he could, he generally shoved himself along on his breast, and often used his wings and bill to help himself forward. All his descendants are just like him.

William Davenport Hulbert.

\section{MARTIN, PURPLE}

The purple martin is very common throughout the south. . . . In the northern states it is a comparatively rare bird of local distribution and is apparently decreasing in numbers each year.

Chapman. Handbook of Birds. ${ }^{21}$

The martin originally built in hollows of trees, as the white-bellied swallow still does, but is now seldom if ever known to nest except in artificial receptacles.

Stearns. New England Bird Life. ${ }^{30}$ 


\section{Martin, Purple}

The services of the martin in driving away hawks and crows from the premises he claims are important inducements for favor. He has even the courage to attack the redoubtable kingbird, when his visits are too familiar near the nest.

$$
\text { Nuttall's Ornithology. }{ }^{21}
$$

Wasps, beetles, and all manner of injurious garden insects constitute its diet-another reason for its universal popularity.

It is simple enough to distinguish the martins from the other swallows by their larger size and iridescent dark coat, not to mention their song, which is very soft and sweet, like musical laughter, rippling up through the throat.

Neltje Blanchan. Bird Neighbors. ${ }^{23}$

Surpassed by no bird in swiftness, there is none that equals him in the beauty of his movements on the wing, uniting grace and vivacity in a remarkable degree. Often skimming the surface of ponds, or gliding swiftly along a public road a few feet from the ground, then soaring above the height of the lower clouds, he sails about with but little motion of the wings, till he is out of sight. These flights seem to be made for his own amusement; for it cannot be supposed that he finds the larger insects that constitute his prey at so great a height.

FlagG. A Year With the Birds. ${ }^{25}$ 


\section{MEADOWLARK}

To many the meadowlark is "only a voice." His back is so nearly the color of the meadow, it takes a keen eye indeed to discover him. His beauty-a golden-yellow vest adorned with a necklace of richest jet-is reserved for his mate.

The bobolink's mood is one of care-free happiness; the meadow-lark's suggests the fervent joy that is akin to pain.

Florence A. Merriam. Birds of Village and Field. ${ }^{1}$

I see a lark flashing his white tail and showing his handsome yellow breast with its black crescent like an Indian locket.

Thoreau. Summer. ${ }^{13}$

His flight is very characteristic, consisting of a few rapid movements and then a long sail. Shelley's lines, though written of another bird, fit him to perfection:

In the golden lightning Of the sunken sun,

O'er which clouds are brightening Thou dost float and run.

M. A. Willcox. The Common Land Birds of New England. ${ }^{29}$

What a twang there is about this bird and what vigor! It smacks of the soil. It is the winged embodiment of the spirit of our spring meadows. What emphasis in its "z-d-t, z-d-t," and what character in its long piercing 


\section{Meadowlark}

note! Its straight, tapering, sharp bill is typical of its voice. . . . "Spring o' the year! spring o' the year!" it says, with a long-drawn breath, a little plaintive, but not complaining or melancholy.

Burroughs. Birds and Poets. ${ }^{10}$

Great tenderness, almost pathos, is expressed in the liquid sympathetic voice of these faithful creatures.

Stearns. New England Bird Life. ${ }^{31}$

A piercing shaft of song which seems to cleave the air straight from the hillside meadow beyond-"I see; I see you."

Gibson. Strolls by Starlight and Sunshine. ${ }^{33}$

Nuttall gives it as "et-se-dée-àh."

Oh meadow lark!

From dawn to dark

Your carol quaint is ringing,

And ne'er did float from thrush's throat,

Song sweeter than your simple note,

Of sunny summer singing.

Selected.

\section{NIGHTHAWK}

The only exceptions that can be taken to the name are that it is not a "night" bird, as it flies about mostly at dusk, sometimes at midday, nor yet is it a hawk, being called so only from a resemblance when on the wing, and in its general appearance at a distance.

Parkhurst. The Birds' Calendar. ${ }^{31}$ 


\section{Nighthawk}

Anyone disliking the name, however, surely can not complain of a limited choice of other names, by which, in different sections of the country, it is quite as commonly known,- - night-jar, bull-bat, mosquito hawk, will-o'-the wisp, pisk, piramidig, long-winged goatsucker.

Neltje Blanchan. Bird Neighbors. ${ }^{23}$

It has almost no bill at all, merely a hook and eye for a wide gaping mouth.

Florence A. Merriam. Birds Through an Opera Glass. ${ }^{2}$

When flying, the white mark on their primaries is a conspicuous character, and has the appearance of being a hole in the bird's wing.

Chapman. Handbook of Birds. ${ }^{21}$

The ærial evolutions of the nighthawk are remarkable. It soars and it flaps, it twists and it turns, it mounts perpendicularly into the air-all with graceful ease; and in the nesting season its performances are a seven days' wonder for all beholders. When high in the air, it shoots down almost to the earth, and then, turning abruptly, ascends to the same heights. In diving, the air is forced through its wings, making a booming sound, which Nuttall describes as "resembling that produced by blowing strongly" into the bung of an empty hogshead."

Florence A. Merriam. Birds of Village and Field. ${ }^{1}$ 


\section{Nighthawk}

This booming sound, coming from such a height that the bird itself is often unseen, was said by the Indians to be made by the shad spirits to warn the schools of shad, about to ascend the rivers to spawn in the spring, of their impending fate.

Netlue Blanchan. Bird Neighbors. ${ }^{23}$

They roost upon a large and nearly horizontal branch in a longitudinal direction. The design of nature in this instinct is to afford the bird that concealment which is needful for its protection in the daytime. When thus placed he is entirely hidden from sight below.

If his foe were looking down upon him, he would hardly be distinguished, his mottled-brown plumage making no contrast in color with the bark of the tree.

FlaGg. A Year With the Birds. ${ }^{25}$

\section{CALL-Note:}

A sharp "eek" or "peent."

Florence A. Merriam.

A shrill note that has been likened to the word Piramidig.

FlagG.

An indescribable squeak.

PARKhURST.

A single note, of a guttural-nasal quality, almost indistinguishable from the so-called bleat of the woodcock.

TORREY. 


\section{Nighthawk}

In devious circles round and round,

The nighthawk coursed the twilight sky,

Or shot like lightning the profound,

With breezy thunder in the cry

That marked his furious rebound.

J. G. Holland.

\section{NUTHATCH, WHITE-BREASTED}

The name nuthatch has been bestowed on this family of birds from their supposed practice of breaking nuts by repeated hatchings, or hammerings with their bills. It is said that they lay up a large store of nuts for winter, but . . . I am inclined to doubt the fact. . . . . . I have every reason to believe that ants, bugs, small seeds, insects and their larvæ form their chief subsistence.

Wilson.

A lady forgetting his name once aptly described him to me as "that little upside-down bird," for he will run along the under side of a branch with as much coolness as a fly would cross a ceiling.

Audubon observes that he sleeps hanging head down. Florence A. Merriam. Birds Through an Opera Glass. ${ }^{2}$

They have little fear, but a great deal of curiosity. In a very pert and comical manner one will stretch out its neck, cock its head on one side, and coolly examine a person passing by. But the difference between impudent boldness and artless inquisitiveness is as easily distinguishable in a bird as in a human being.

Parkhurst. The Birds' Calendar. ${ }^{31}$ 


\section{Nuthatch, White-Breasted}

When the trees are incased in ice, which, though not impenetrable by their strong bills, prevents the discovery of their food, they are in danger of starving. . . . . Driven by this necessity from their usual haunts, a piece of suet fastened firmly to the branch of a tree, at any time of the winter, would soon be discovered by them and afford them a grateful repast.

FLAGG. A Year With the Birds. ${ }^{25}$

There is such a lack of sentiment in the nuthatch's character, he seems so matter-of-fact in all his ways, that it is difficult to imagine him indulging in anything like song. But even he cannot withstand the all-conquering influences of spring, and at that season he raises his voice in a peculiar monotone-a tenor hah-hah-hah-hah-hahsounding strangely like mirthless laughter.

Chapman. Handbook of Birds. ${ }^{21}$

\section{CALL-Note:}

Ick-ick-ick.-STEARNS.

Kauk-kauk.-NuTTALL.

A loud nasal yank, yank.-ChapMAN.

Yak, yak, yak, yak-ah, ak-ah.-Merriam.

Quah-quah.-THOREAU.

Up and down the maples rough and shaggy-coated, Busy searching through the lichens all the day, Shyly creeps the tiny nuthatch snowy-throated, Sharply eyeing every crevice for its prey. 


\section{Nuthatch, White-Breasted}

\section{To a Nuthatch}

Shrewd little haunter of woods all gray, Whom I meet on my walk of a winter dayYou're busy inspecting each cranny and hole In the ragged bark of yon hickory bole; You intent on your task, and I on the law Of your wonderful head and gymnastic claw!

The woodpecker well may despair of this featOnly the fly with you can compete! So much is clear; but I fain would know How you can so reckless and fearless go, Head upward, head downward, all one to you, Zenith and nadir the same in your view.

Edith M. Thomas.

\section{NUTHATCH, RED-BREASTED}

This bird is smaller than the white-breasted nuthatch, and can be recognized at a glance by the stripes on its head, and the reddish brown of its breast.

Florence A. Merriam. Birds of Village and Field. ${ }^{1}$

The notes of this species, though similar to the whitebreasted, are sharper, resembling day day dait, and sounding almost like a child's trumpet. Its motions are also quicker.

Nuttall's Ornithology. ${ }^{26}$ 



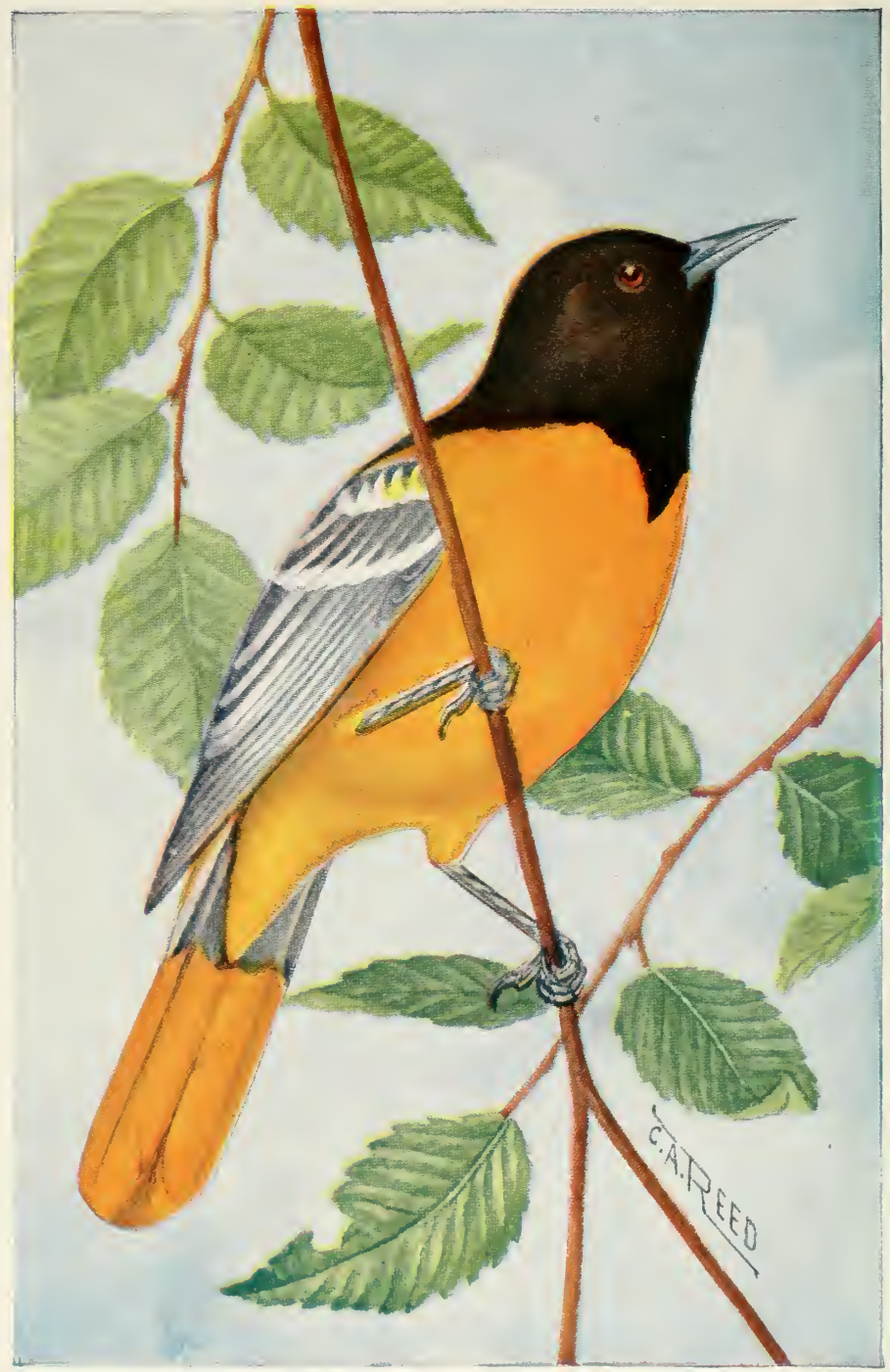




\section{ORIOLE, BALTIMORE. GOLDEN ROBIN. FIRE BIRD. ENGLISH ROBIN. HANG-NEST}

A flash of fire through the air; a rich, high, whistled song floating in the wake of the feathered meteor; the Baltimore oriole cannot be mistaken.

Neltje Blanchan. Bird Neighbors. ${ }^{23}$

I always look for the Baltimore oriole when the cherry trees burst into blossom, and at no time does its beautiful plumage appear to better advantage than when seen against a background of white flowers.

Chapman. Bird Life. ${ }^{22}$

Among all the designs of nests, in this country at least, there is nothing more picturesque than the deep, pendulous structure of the Baltimore oriole, hanging from near the extremity of a drooping branch of an elm-tree, nearly seven inches in depth, of cylindrical shape, the outer part a sort of coarsely woven cloth made of thread, sewing silk, ravellings of any kind, strings of the flax of silk-weed, tow, etc., with a lining of horse-hair, grass and similar material.

Parkhurst. The Birds' Calendar. ${ }^{31}$

Before the advent of civilization in this country, the oriole probably built a much deeper nest than it usually does at present. When now it builds in remote trees and along the borders of the woods, its nest, I have noticed, is long and gourd-shaped; but in orchards and near dwellings it is only a deep cup or pouch.

Burroughs. Signs and Seasons. ${ }^{7}$ 


\section{Oriole, Baltimore. Golden Robin. Firebird. English Robin. Hang-Nest}

Few birds like the hairy caterpillars, but Dr. Fisher has seen the oriole go up before a caterpillar's nest and, after puncturing it with his bill, stand and wait for the caterpillars to come out. As each one appeared he seized it and after sucking the juices of its body threw away the hairy skin covering.

Florence A. Merriam. Birds of Village and Field. ${ }^{1}$

Until too much engrossed with family duties, the beautiful birds sing a great deal. . . . There is a bright vivacious song, an equally hearty scold, a high, shrill whistle, and a richly modulated love song.

Florence A. Merriam. Birds of Village and Field. ${ }^{1}$

How falls it, oriole, thou hast come to fly

In tropic splendor through our Northern sky?

At some glad moment, was it Nature's choice

To dower a scrap of sunset with a voice?

Or did some orange tulip flaked with black,

In some forgotten garden, ages back,

Yearning towards heaven, until its wish was heard,

Desire unspeakably to be a bird?

Edgar FAwCETT.

How still the air is!

There an oriole flew;

What a jolly whistle!

He's a sailor, too. 


\title{
Oriole, Baltimore. Golden Robin. Firebird. English Robin. Hang-Nest
}

\author{
Yonder is his hammock \\ In an elm-top high: \\ One more ballad, messmate! \\ Sing it as you fly!
}

Lucy Larcom.

The oriole with experienced quest

Twitches the fibrous bark away,

The cordage of his hammock-nest,

Cheering his labor with a note

Rich as the orange of his throat.

LOWELL.

My Oriole, my glance of summer fire,

Is come at last, and ever on the watch, Twitches the pack-thread I had lightly wound About the bough to help his housekeeping,-Twitches and scouts by turns, blessing his luck, Yet fearing me who laid it in his way, Nor, more than wiser we in our affairs, Divines the providence that hides and helps. Heave, ho! heave, ho! he whistles as the twine Slackens its hold; once more, now! and a flash Lightens across the sunlight to the elm Where his mate dangles at her cup of felt.

LOWELL.

"Come here! come here! Summer is on the way!" The oriole is calling in the blossom-time of May.

Selected. 
Early in May you may have the good fortune to see this little bird of the woods strutting in and out of the garden shrubbery with a certain mock dignity like a child wearing its father's boots. Few birds can walk without appearing more or less ridiculous, and however gracefully and pretty it steps, this amusing wagtail is no exception.

Neltje Blanchan. Bird Neighbors. ${ }^{23}$

As an architect the oven-bird is distinguished. His unique nest is built on the ground, of coarse grasses, weedstalks, leaves and rootlets, and is roofed over, the entrance being at one side. It thus resembles an old-fashioned Dutch oven, and its shape is the origin of its builders' name.

Chapman. Bird Life. ${ }^{22}$

If there be such a thing as inspiration, I believe the oven-bird sings under its influence. . . . Flying up from the ground, how cautiously he hops from branch to branch, and with crest slightly erect, walks carefully along a limb, when, suddenly overcome by the music in his soul, he throws fear to the winds and lifts up his voice in a crescendo chant which vibrates through the woods. Teacher, teacher, TEACHER, TEACHER, Mr. Burroughs writes it, and the description is difficult to improve upon. The bird fairly quivers with the violence of his effort.

Chapman. Handbook of Birds. ${ }^{21}$

He has a far rarer song which he reserves for some nymph whom he meets in the air. Mounting by easy flights to 


\section{Oven-Bird. Golden-Crowned Thrush}

the top of the tallest tree, he launches into the air with a sort of suspended, hovering flight . . . . and bursts into a perfect ecstasy of song, clear, ringing, copious, rivalling the goldfinch's in vivacity, and the linnet's in melody. This strain is one of the rarest bits of bird-melody to be heard.

Burroughs. Wake Robin. ${ }^{5}$

\section{The Oven-Bird}

In the days of spring migrations,

Days when warbler hosts move northward,

To the forests, to the leaf-beds,

Comes the tiny oven-builder.

Daintily the leaves he tiptoes;

Underneath them builds his oven, Arched and framed with last year's oak leaves, Roofed and walled against the rain-drops.

Hour by hour his voice he raises, Mingling with the red-eye's snatches, Answering to the hermit's anthem; Rising-falling, like a wind breath.

Strange, ventriloquous his music, Far away when close beside one;

Near at hand when seeming distant;

Weird-his plaintive accrescendo.

Teach us! teach us! is his asking, Uttered to the Omnipresent:

Teach us! teach us! comes responsive From the solemn listening forest.

Bolles. Chocorua's Tenants. ${ }^{19}$ 


\section{OWLS}

Owls are nocturnal birds of prey, and for this reason feed more largely on small mammals--most of which are nocturnal-than the diurnal birds of prey. They are therefore of even greater value to the agriculturist than hawks.

Chapman. Handbook of Birds. ${ }^{21}$

Owls have little flaps of skin with which they can shut up their ears when they wish to be quiet.

Olive Thorne Miller. First Book of Birds. ${ }^{3}$

Owls' eyes are so fixed in their sockets that they cannot look from one point to another by simply "rolling" the eyeball, but are obliged to turn their head.

Chapman. Handbook of Birds. ${ }^{21}$

The owl is the great bugaboo of the feathered tribes. His appearance by day is hailed by shouts of alarm and derision from nearly every bird that flies, from crows down to sparrows. They swarm about him like flies, and literally mob him back into his dusky retreat.

Burroughs. Birds and Poets. ${ }^{10}$

His occupancy of deserted houses and ruins has invested him with a romantic character . . . . He deserves in a special degree to be classed among those animals which we call picturesque.

FLAGG. A Year With the Birds. ${ }^{25}$ 


\section{Owls}

Bird of the silent wing and expansive eye, grimalkin in feathers, feline, mousing, haunting ruins and towers, and mocking the midnight stillness with thy uncanny cry!

Burroughs. Birds and Poets. ${ }^{10}$

I rejoice that there are owls. Let them do the idiotic and maniacal hooting for men. It is a sound admirably suited to swamps and twilight woods.

Thoreau. Walden. ${ }^{16}$

\section{The Owl and the Echo}

\section{A FABLE}

An owl puffed up with pride and vanity was repeating his doleful cries at midnight from the hollow of an old oak. "How is it," he said, "that silence prevails in this wood, unless it be to allow my melodious voice to be heard with effect? Surely the groves are charmed with my voice, and when I sing all nature listens."

An echo repeated the words, "All nature listens." "The nightingale has usurped my rights," continued the owl. "His note is sweet, it is true, but mine is much more melodious."

"Much more melodious," repeated the echo. Excited by approval, the owl, at the rising of the sun, instead of going to sleep as usual, continued to join his hooting with the matin songs of the other birds. But they were disgusted by the sounds and with one consent attacked the owl and drove him from their society, harassing him wherever he appeared, so that to escape from them he was glad to avoid the light and return to obscurity.

Vain people fancy that their imaginary perfections are the cause of admiration in others and mistake their self-flattery for the voice of fame.

Selected. 


\section{RUFFED GROUSE. PARTRIDGE}

The ruffed grouse, or partridge of the north and pheasant of the south, is properly a true grouse, and cannot be correctly called either partridge or pheasant.

Chapman. Bird Life. ${ }^{22}$

Their way of scratching in the snow, resting their weight on one foot and scratching with the other is like that of the common hen, and their drumming is the finished performance that is caricatured by chanticleer. Drumming with the partridge is a joy.

Florence A. Merriam. Birds Through an Opera Glass. ${ }^{2}$

Who has seen the partridge drum? It is the next thing to catching a weasel asleep, though by much caution and tact it may be done. He selects not, as you would predict, a dry and resinous log, but a decayed and crumbling one, seeming to give the preference to old oak logs that are partly blended with the soil. . . . He does not hug the log, but stands very erect, expands his ruff, gives two introductory blows, pauses half a second, and then resumes, striking faster and faster until the sound becomes a continuous, unbroken whir, the whole lasting less than half a minute.

BurRoughs. Wake Robin. ${ }^{5}$

To find a hen grouse with young is a memorable experience. While the parent is giving us a lesson in motherlove and bird intelligence, her downy chicks are teaching us facts in protective coloration and heredity. How the old one limps and flutters! She can barely drag herself 


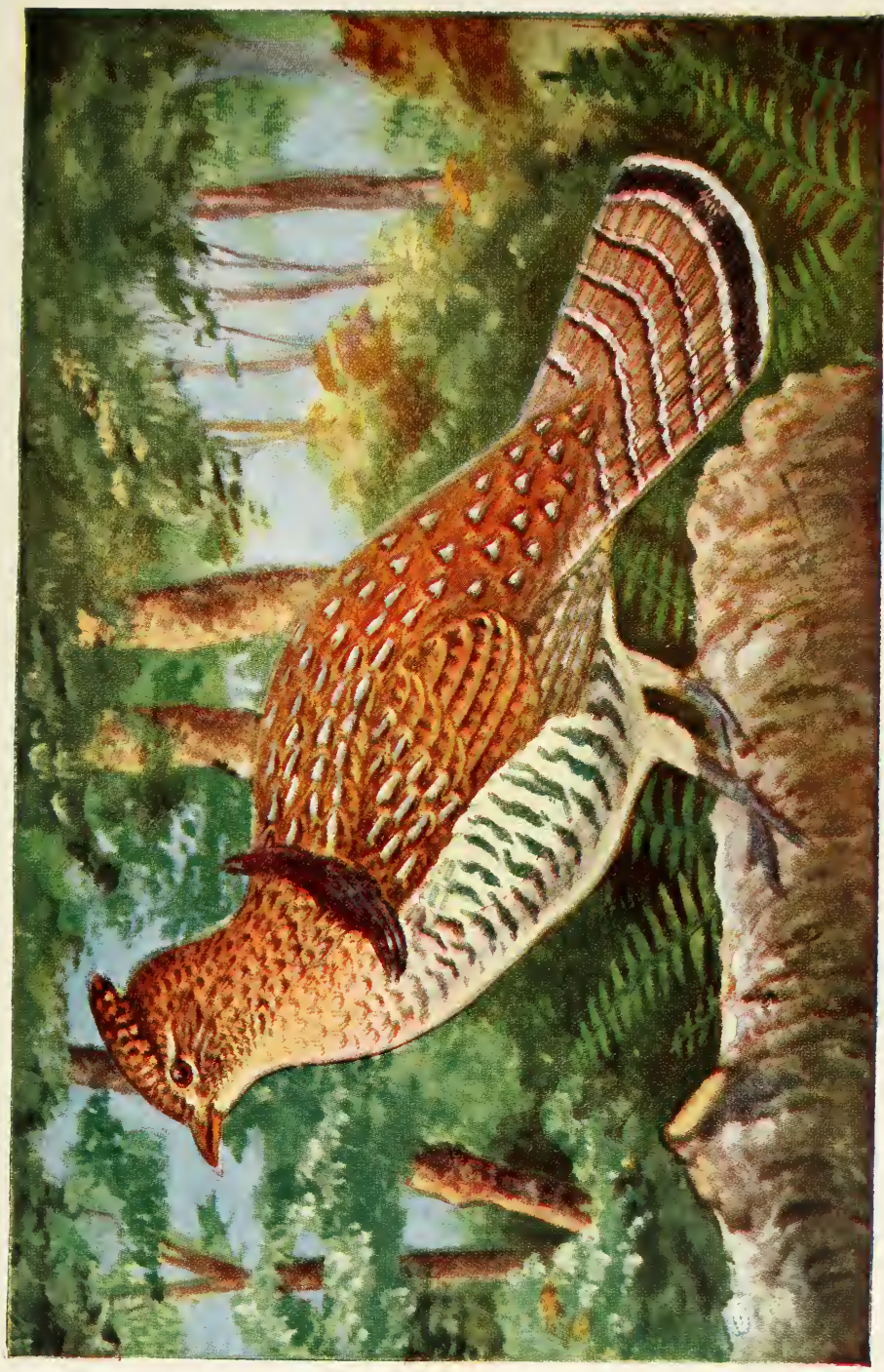





\section{Ruffed Grouse. Partridge}

along the ground. But while we are watching her, what has become of the ten or a dozen little yellow balls we almost stepped upon. Not a feather do we see, until, poking about in the leaves, we find one little chap hiding here and another squatting there, all perfectly still, and so like the leaves in color as to be nearly invisible.

Chapman. Bird Life. ${ }^{22}$

Nature has not asked this bird to walk the snows for its living without providing it with proper means of locomotion. With its slender summer foot it would sink in the soft drift at every step, while now it walks with perfect ease on the lightest snow, for each foot is provided with a snow-shoe. Every autumn the shoe begins to grow, a stiff fringe of horny bristles spreading around the sole and on both sides of each toe, until, by the time the blizzard arrives, the bird is ready to walk on the highest drifts. The intention of this bristly growth is perfectly plain, for in April, when the snows have melted you may look in vain for the snow-shoe; the grouse has kicked it off as a thing that has served its purpose.

Gibson. Sharp Eyes. ${ }^{32}$

Then it is the stately partridge

Spreads his ruff and mounts his rostrum,

Gazes proudly round the thicket,

Sounds his strange and muffled signal.

First with slow and heavy measure,

Then like eager, hurried heart-beats,

Ending in a nervous flutter

Faster than the ear can reckon.

Bolles. Chocorua's Tenants. ${ }^{19}$ 


\section{PEWEE, WOOD}

The chances are that you will find it perched on a dead twig of some tall tree projecting into open space. There it will look down for insects that may pass beneath, and, sighting one, it glides gracefully downward, seizes the insect, and then returns to its perch with a graceful upward curve that shows how beautiful a movement flight may be.

\section{Аввотт. Birds About Us. ${ }^{27}$}

It is always hungry. I have seen it at sunrise darting at flies in the chilly, dismal, fog-laden air, and until noon, though the woods were as another Inferno, still at work, instead of resting when other birds were taking a nap; not even during the quiet of mid-afternoon, when the sun seemed to have paused in his career; no, nor yet at sundown, when even the last robin had chirped to the world "good night"; but at last, when, in the fading light, its skill was no longer equal to the task, it, too, bade me farewell, its mournful, tired-out pe-a-wee being the last bird-sound of the day.

Аввотт. Birdland Echoes. ${ }^{28}$

The wood pewee's nest is essentially woodsy and distinctive. It is an exquisite little structure, saddled on to a lichen-covered limb. Made of fine roots and delicate stems of grass and seed pods, it is covered with bits of lichen or moss glued on with saliva, so that like the humming bird's nest it seems to be a knob on the branch.

Florence A. Merriam. Birds Through an Opera Glass. ${ }^{2}$ 


\section{Pewee, Wood}

His pensive, gentle ways are voiced by his sad, sweet call. The notes are as musical and restful, as much a part of Nature's hymn, as the soft humming of a brook.

Chapman. Handbook of Birds. ${ }^{21}$

He repeats his "sweetly solemn thought" over and over again, all day long and every day throughout the summer.

Neltje Blanchan. Bird Neighbors. ${ }^{23}$

\section{The Pewee}

The listening Dryads hushed the woods;

The boughs were thick, and thin and few

The golden ribbons fluttering through;

Their sun-embroidered, leafy hoods

The lindens lifted to the blue;

Only a little forest-brook

The farthest hem of silence shook;

When in the hollow shades I heard--

What is it, a spirit or a bird?

Or, strayed from Eden, desolate,

Some Peri calling to her mate,

Whom nevermore her mate would cheer?

"Peri! peri! peer!"

To trace it in its green retreat

I sought among the boughs in vain;

And followed still the wandering strain,

So melancholy and so sweet,

The dim-eyed violets yearned with pain. 


\section{The Pewee}

'Twas now a sorrow in the air, Some nymph's immortalized despair Haunting the woods and waterfalls; And now, at long, sad intervals, Sitting unseen in dusky shade, His plaintive pipe some fairy played, With long-drawn cadence thin and clear,"Pe-wee! pe-wee! peer!"

I quit the search, and set me down Beside the brook, irresolute, And watched the little bird in suit Of sober olive, soft and brown,

Perched in the maple branches, mute; With greenish gold its vest was fringed, Its tiny cap was ebon-tinged, With ivory pale its wings were barred, And its dark eyes were tender-starred. "Dear bird," I said, "What is thy name?" And thrice the mournful answer came, So faint and far, and yet so near,-"Pe-wee! pee-wee! peer!"

John T. TROWBRIDGE.

\section{PHOEBE. WATER PEWEE}

There he sits on a branch, in an attitude that would shock the neat songsters. His wings droop at his sides, and his tail hangs down in the most negligent fashion. $\mathrm{He}$ seems the personification of listlessness; but,--focus your glass on him,--his wings are vibrating, and his tail jerks nervously at intervals. Suddenly he starts into 


\section{Phoebe. Water Pewee}

the air, snaps his bill loudly over an unsuspecting insect he has been lying in wait for, and, before you breathe, settles back on the branch with a spasmodic jerk of the tail.

Florence A. Merriam. Birds Through an Opera Glass. ${ }^{2}$

The note is a somewhat harsh and querulous one, resembling the word phœbe. The first syllable is smooth, the second rough and broken.

M. A. Willcox. The Common Land Birds of New England. ${ }^{29}$

In Florida the phœbe is said to light on the backs of cattle, taking a ride with the laudable excuse of catching flies.

Florence A. Merriam. Birds of Village and Field. ${ }^{1}$

When not domesticated, as these birds are rapidly becoming, the phœbes dearly love a cool, wet woodland retreat. Here they hunt and bathe; here they also build in a rocky bank or ledge of rocks, or underneath a bridge, but always with clever adaptation of their nest to its surroundings, out of which it seems a natural growth. It is one of the most finished, beautiful nests ever found. A pair of phœbes become attached to a spot where they have once nested; they never stray far from it, and return to it regularly (they are mated for life), though they do not again occupy the old nest.

Neltue Blanchan. Bird Neighbors. ${ }^{23}$ 


\section{Phoebe. Water Pewee}

Phœbe is a devoted parent, and is rarely found far from home. His nest seems to be the favorite abode of an innumerable swarm of parasites, which sometimes cause the death of his offspring. . . . . . There is something familiar, trustful and homelike in the phœbe's ways which has won him an undisputed place in our affections.

Chapman. Handbook of Birds. ${ }^{21}$

It is a wee, sad-colored thing,

As shy and secret as a maid, That, ere in choir the robins ring,

Pipes its own name like one afraid.

LOWELL.

\section{QUAIL. BOB-WHITE}

$\mathrm{He}$ is neither a true quail nor a partridge and those who claim that but one of these names is correct may compromise on "Bob-white."

Chapman. Bird Life. ${ }^{22}$

As a weed-seed and insect destroyer it is of such economic importance that in Wisconsin, where it has been practically exterminated, attempts have recently been made to reestablish it. It eats the potato beetle, and it is particularly fond of the moth that lays the egg that produces the injurious, omnivorous cutworm.

Florence A. Merriam. Birds of Village and Field. ${ }^{1}$ 


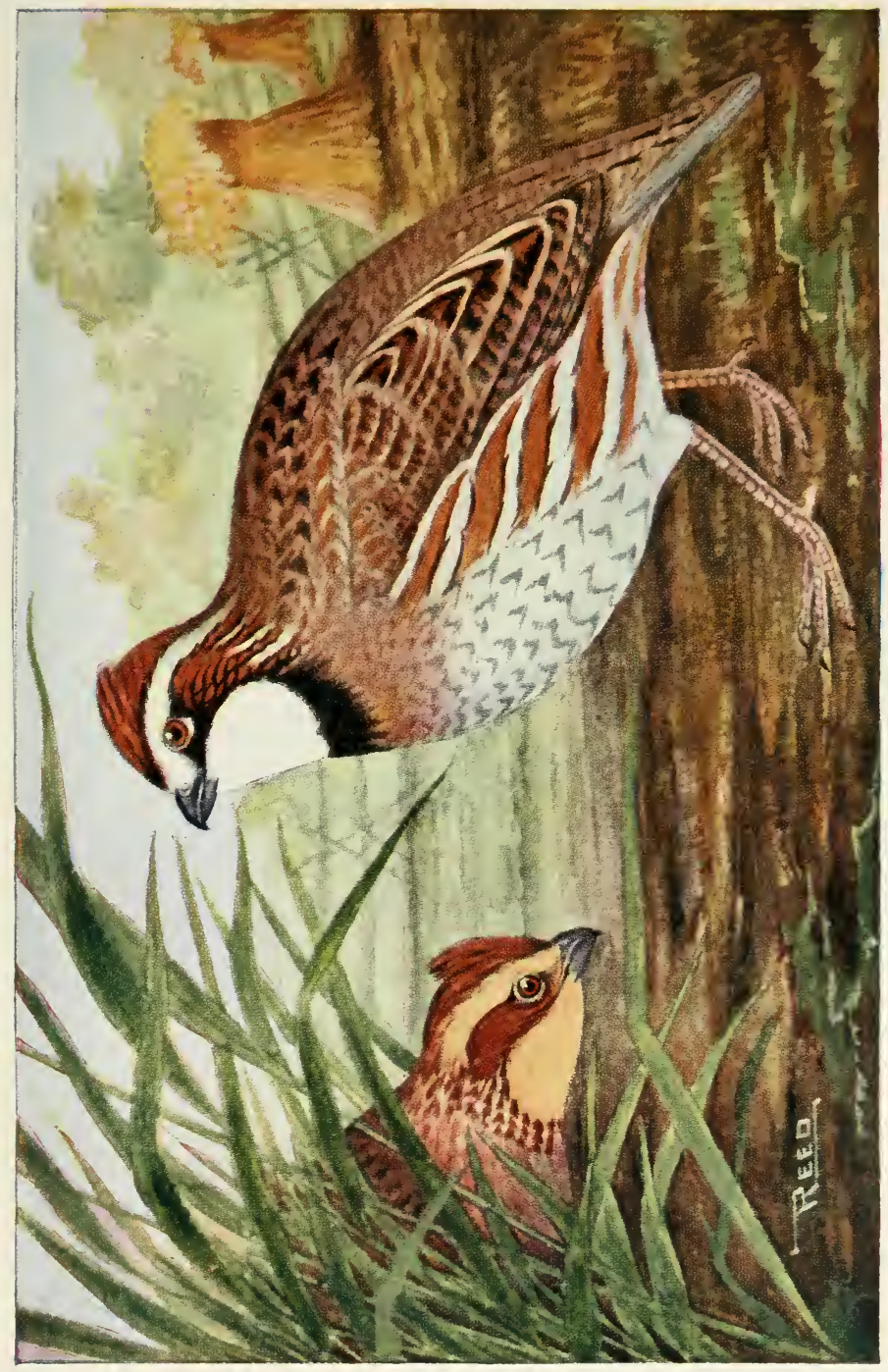





\section{Quail. Bob-White}

There are few prettier sights than a family of old quail with their young walking fearlessly about in a woodland meadow. The bird's domestic life is particularly interesting from the part the male plays in the family, helping to build the nest, feeding his mate on the eggs, and, in case of her death, brooding in her place.

Florence A. Merriam. Birds of Village and Field. ${ }^{1}$

At night, for at least many days in succession, the quail selects the same spot to sleep in, more usually on low ground, where the long grass affords shelter and warmth. There they encamp, not huddled together promiscuously and unadvisedly, but shoulder to shoulder in a circle, with their heads out, so that in the event of a sudden surprise they escape rapidly, and in every direction, without difficulty. . . . . In winter, they lie on the ground as usual, always allowing the snow to accumulate until morning, when they free themselves by united effort. Should a crust be formed, they frequently find it impossible to escape, and so perish.

Minot. Land and Game Birds. ${ }^{20}$

The destruction of this useful and interesting species by our winter snows is a public calamity; and nothing, it seems to me, can mitigate the evil save the building of artificial shelters, strewing around them some sort of grain to prevent their wandering far away from them. Our farmers have not sufficiently considered the advantages they might derive from this semi-domestication of the quail and some other species that winter with us.

FLAGG. A Year With the Birds. ${ }^{25}$ 


\section{Quail. Bob-White}

\section{Bob White}

There's a plump little chap in a speckled coat, And he sits on the zigzag rails remote, Where he whistles at breezy, bracing morn, Where the buckwheat is ripe, and stacked the corn:

"Bob White! Bob White! Bob White!"

Is he hailing some comrade as blithe as he? Now I wonder where Robert White can be! O'er the billows of gold and amber grain There is no one in sight--but hark again:

"Bob White! Bob White! Bob White!"

Ah! I see why he calls; in the stubbles there Hide his plump little wife and babies fair!

So contented is he, and so proud of the same, That he wants all the world to know his name, "Bob White! Bob White! Bob White!"

Selected.

\section{REDPOLL. REDPOLL LINNET}

Erelong, amid the cold powdery snow, as it were a fruit of the season, will come twittering a flock of delicate, crimson-tinged birds, lesser redpolls, to sport and feed on the seeds and buds just ripe for them on the sunny side of a wood, shaking down the powdery snow there in their cheerful feeding, as if it were high midsummer to them.

Thoreau. Autumn. ${ }^{14}$ 


\section{Redpoll. Redpoll Linnet}

The redpolls are occasionally the most abundant of our winter birds, but, on the other hand, several successive winters often pass without their occurrence in Massachusetts. . . . They wander continually during their visits, and hence are very irregular in appearance at different localities. I have never observed them to feed from the evergreens, but they have a marked fondness for the seeds of white birches and alders.

\section{Minot. Land and Game Birds. ${ }^{20}$}

Famine, in all probability, or the scarcity of food, urges them to advance toward the south. It is certain that they do not forsake their natal regions to seek shelter from the cold.

Nuttall's Ornithology. ${ }^{26}$

In the birches, on the grasses

Stiffly rising through the snow crust,

On the slope of yonder sand-bank

Where the snow has slipped and wasted,

Rest a flock of trustful strangers,

Lisping words of gentle greeting,

Rest and find the sun's rays warming,

Rest and find their food abundant,

Resting, sing of weary journeys

From a Northland cold and distant.

Rose-touched are their brows, with tints like

Lights upon a winter's snow-field, 


\section{Redpoll. Redpoll Linnet}

Rosy are their caps as morning

When the storm clouds gather eastward,

Happy are their hearts and voices,

Happy are the fields and forests,

When their merry notes come jingling,

Sleighbell like, from upper ether.

Bolles. Chocorua's Tenants. ${ }^{19}$

\section{REDSTART}

The Germans call this little bird roth Stert (red tail), but, like so many popular names, this is a misnomer, as, strictly speaking, the redstart is never red, though its salmon-orange markings often border on to orange-flame.

Neltje Blanchan. Bird Neighbors. ${ }^{23}$

If the male redstart is a fiery coal, the female is a trail of ashes in his wake.

Parkhurst. The Birds' Calendar. ${ }^{31}$

In Cuba most of our wood warblers are known simply as "Mariposas"--butterflies; but the redstart's bright plumage has won for him the name "Candelita"--the little torch that flashes in the gloomy depths of tropical forests.

Chapman. Handbook of Birds. ${ }^{21}$

They show warbler blood by the mad way they career about, opening and shutting their tails fan-fashion, turning somersaults, flitting from branch to branch, stopping a 


\section{Redstart}

second to give a little burst of song, and then fluttering round again; chasing helter-skelter among the bushes; and suddenly falling through the leaves as if they had been shot, only to snap up their prey and dart off to begin their gambols over again.

Florence A. Merriam. Birds Through an Opera Glass. ${ }^{2}$

The redstart folds and unfolds his twinkling tail in sport.

Olive Thorne Miller.

\section{ROBIN, AMERICAN}

The most native and democratic of all our birds.

Burroughs. Wake Robin. ${ }^{5}$

His red breast is a myth and belongs to his English namesake, and it must be owned that his is a homely reddish brown that looks red only when the sunlight falls on it. . . . . He has . . . . a calm, dignified air. With time to meditate when he chooses, like other sturdy, well-fed people, his reflections usually take a cheerful turn; and when he lapses into a poetical mood, as he often does at sunrise or sunset, sitting on a branch in the softened light and whispering a little song to himself, his sentiment is the wholesome, every-day sort . . . . full of contented appreciation of the beautiful world he lives in.

Florence A. Merriam. Birds Through an Opera Glass. ${ }^{2}$ 


\section{Robin, American}

Too much stress is laid on the mischief done by the robins in the cherry trees and strawberry patches and too little upon the quantity of worms and insects they devour.

\section{Neltje Blanchan. Bird Neighbors. ${ }^{23}$}

His flight is rapid, clear-cut and straight. Unlike many birds, he moves as if he were going somewhere.

Florence A. Merriam. Birds Through an Opera Glass. ${ }^{2}$

The robin is the Philomel of morning twilight in New England and in all the northeastern states of this continent. If his sweet notes were wanting, the mornings would be like a landscape without the rose, or a summer-evening sky without tints. He is the chief performer in the delightful anthem that welcomes the rising day. . . . . Remove the robin from this woodland orchestra and it would be left without a soprano.

FLAGG. A Year With the Birds. ${ }^{25}$

I know of no other bird that is able to give so many shades of meaning to a single note, running through the entire gamut of its possible feelings. From the soft and mellow quality, almost as coaxing as a dove's note, with which it encourages its young when just out of the nest, the tone, with minute gradations, becomes more vehement and then harsh and with quickened reiteration, until it expresses the greatest intensity of a bird's emotions. Love, contentment, anxiety, exultation, rage--what other animal can throw such multifarious meaning into its tone? And 


\section{Robin, American}

herein the robin seems more nearly human than any of its kind.

$$
\text { Parkhurst. The Birds' Calendar. }{ }^{31}
$$

The sweetest sound the whole year round;

'Tis the first robin of the spring!

The song of the full orchard choir

Is not so fine a thing. $\quad$ E. C. Stedmax.

\section{Robin}

When the willows gleam along the brooks, And the grass grows green in sunny nooks, In the sunshine and the rain

I hear the robin in the lane

Singing, "Cheerily,

Cheer up, cheer up;

Cheerily, cheerily, Cheer up."

But the snow is still

Along the walls and on the hill,

The days are cold, the nights forlorn

For one is here and one is gone.

"Tut, tut, Cheerily,

Cheer up, cheer up;

Cheerily, cheerily,

Cheer up."

When spring hopes seem to wane,

I hear the joyful strain--

A song at night, a song at morn, 
Robin, American

A lesson deep to me is borne, Hearing, "Cheerily, Cheer up, cheer up; Cheerily, cheerily, Cheer up."

\section{Robin's Return}

Robin on the tilting bough, Red-breast rover, tell me how

You the weary time have passed

Since we saw and heard you last.

"In a green and pleasant land, By a summer sea-breeze fanned, Orange-trees with fruit are bent; There the weary time I've spent."

Robin rover, there, no doubt, Your best music you poured out;

Piping to a stranger's ear, You forgot your lovers here.

"Little lady, on my word, You do wrong a true-heart bird!

Not one ditty would I sing,

'Mong the leaves or on the wing.

"In the sun or in the rain, Stranger's ear would list in vain. If I ever tried a note, Something rose within my throat. 


\section{Robin, American}

" 'Twas because my heart was true

To the North and spring-time new;

My mind's eye a nest could see

In yon old, forked apple-tree."

Edith M. Thomas.

(Note.) It is said that the robin does not sing during its winter stay in the South.

\section{The Robin}

My old Welsh neighbor over the way

Crept slowly out in the sun of Spring,

Pushed from her ears the locks of gray,

And listened to hear the robin sing.

Her grandson, playing at marbles, stopped

And--cruel in sport, as boys will be--

Tossed a stone at the bird, who hopped

From bough to bough in the apple tree.

"Nay," said the grandmother, "have you not heard,

My poor bad boy! of the fiery pit,

And how, drop by drop, this merciful bird

Carries the water that quenches it?

"He brings cool dew in his little bill, And lets it fall on the souls of sin;

You can see the mark on his red breast still

Of fires that scorch as he drops it in. 


\section{Robin. American}

"My poor Bronrhuddyn, my breast-burned bird, Singing so sweetly from limb to limb, Very dear to the heart of our Lord-Is he who pities the lost like Him."

"Amen!" I said to the beautiful myth: "Sing, bird of God, in my heart as well; Each good thought is a drop wherewith To cool and lessen the fires of hell.

"Prayers of love like raindrops fall,

Tears of pity are cooling dew, And dear to the heart of our Lord are all Who suffer like Him in the good they do."

WHITTIER.

\section{Sir Robin}

Rollicking Robin is here again.

What does he care for the April rain?

Care for it? Glad of it. Doesn't he know That the April rain carries off the snow, And coaxes out leaves to shadow his nest, And washes his pretty red Easter vest, And makes the juice of the cherry sweet, For his hungry little robins to eat?

"Ha! ha! ha!" hear the jolly bird laugh.

"That isn't the best of the story by half!"

Gentleman Robin, he walks up and down, Dressed in orange-tawny and black and brown. Though his eye is so proud and his step so firm, 


\section{Robin, American}

He can always stoop to pick up a worm.

With a twist of his head, and a strut and a hop, To his Robin-wife in the peach tree top, Chirping her heart out, he calls: "My dear, You don't earn your living! Come here! Come here!

$\mathrm{Ha}$ ! ha! ha! Life is lovely and sweet; But what would it be if we'd nothing to eat?"

Robin, sir Robin, gay, red-rested knight, Now you have come to us, summer's in sight. You never dream of the wonders you bring,-Visions that follow the flash of your wing; How all the beautiful By-and-by Around you and after you seems to fly! Sing on, or eat on, as pleases your mind! Well have you earned every morsel you find. "Aye! Ha! ha! ha!" whistles Robin, "My dear, Let us all take our own choice of good cheer!"

LUCY Larcom.

\section{The Secret}

We have a secret, just we three, The robin and I and the sweet cherry-tree, The bird told the tree, and the tree told me, And nobody knows it but just we three.

But of course the robin knows it best, Because he built it--I shan't tell the rest; And laid the four little--somethings in it-I am afraid I shall tell it every minute. 


\section{Robin, American}

But if the tree and the robin don't peep,

I'll try my best the secret to keep;

Though I know when the little birds fly about,

Then the whole secret will be out.

SeleCted.

\section{The Robin}

In the tall elm-tree sat the robin bright,

Through the rainy April day,

And he carolled clear with a pure delight,

In the face of the sky so gray.

And the silver rain through the blossoms dropped,

And fell on the robin's coat

And his brave red breast, but he never stopped

Piping his cheerful note.

For, oh, the fields were green and glad,

And the blissful life that stirred

On the earth's wide breast, was full and warm

In the heart of the little bird.

The rain-cloud lifted, the sunset light

Streamed wide over valley and hill;

As the plains of heaven the land grew bright,

And the warm south wind was still.

Then loud and clear called the happy bird,

And rapturously he sang,

Till wood and meadow and river side

With jubilant echoes rang.

But the sun dropped down in the quiet west,

And he hushed his song at last;

All nature softly sank to rest,

And the April day had passed. Celia Thaxter. 


\section{Robin, American}

\section{How the Robin Came}

Long, long ago, in the time almost forgotten, the Indian father called his tall son and said to him, "My boy, your time to go to the forest has come. To the thickest part of the forest, take the mat your mother has made for you. Lie face downward upon it for twelve days and twelve nights. Break not your fast until the twelfth morning, when I will bring you food. These things do to prove your strength sufficient for a warrior. When your days of fasting are completed, the tribe will give a great feast for you. The chief will say, 'Now you are a great warrior.'"

Sad at heart, the boy went to his lonely fast in the forest. Though brave, he did not care to be a warrior, for he loved not war. Neither did he wish to be a hunter for he loved all animals and all birds.

The father went into the wood every morning to visit his son. Until the tenth morning, the youth rose always from his mat in sign of greeting. Much too weak to rise that morning, he begged that he might go home. On the eleventh morning he could but raise his hand in welcome. In the dawn of the twelfth day again came the father, this time with the promised food, for the days of fasting were accomplished.

Already was the tribe preparing a feast for its new warrior. "Come," called the father, "here are your bow and arrow! The chief awaits you!"

No warrior answered the call. No boy was lying face downward in the damp shade.

Then mourned the Indian father, calling, "My son! my son!" The only reply was the song of a bird near by. Some evil spirit has stolen my boy, thought the father. He raised 


\section{Robin, American}

his bow to shoot the bird, but as he did so, the bird flew down to him singing, "O my father, a good spirit has changed me into a bird! See my red breast! See how large and strong I am!"

"O-pe-chee!" called the father, and the robin answered, "Chee! Chee! Chee! Do not grieve for me! Ask the children not to shoot me! Tell them often how I love them! Chee! Chee! Chee!"

Through all the years from that morning until this day, the robin has loved all children and their homes, nesting always near them, staying never in the forest where the red boy lay and fasted.

AdAPTED.

\section{The North Story of How the Robin Got His Red Breast}

Far away in the cold Northland, there was once but a single fire to warm the whole country. An old man and his little son kept it burning by day and by night. They knew that were the fire to go out, all the people in the North country would freeze, and their enemy, the white bear, have all the region for himself.

One day, the old man became so very ill he could no longer guard the fire. For many days and many nights, his little son cared for him and faithfully worked over the fire. At last, however, the boy grew so tired he could not even move about.

Now the white bear also constantly watched the fire, waiting for the hour when the land should belong to him. Seeing at length the great weariness of the boy, he drew near the fire and laughed to himself. Soon he saw the son fall asleep beside his father. Quickly he jumped upon the fire. He beat it with his wet paws and rolled his great body upon it. 


\section{Robin, American}

When he thought the fire quite out, he went happily into his den.

A gray robin flying near had seen the white bear's work. When she was quite certain he had gone away, she flew down to the dying fire and examined it with her little sharp eyes until she saw one clear spark. For a long time she fanned this spark with her wings. Her soft gray breast was burned to a deep red. Still she worked. Finally from the spark she made a flame. Then to every hut in the Northland she flew, and wherever for a moment she rested upon the ground, a bright fire sprang up. Soon instead of one small fire, many fires warmed the country.

The white bear, angry and disappointed, could do nothing but move far back into his cave and growl, for now he knew the Northland would never be his.

So do the people of the Northland love the robin and never do they tire of telling the children how he obtained his red breast.

Adapted.

\section{SANDPIPER, SPOTTED}

I always look forward with pleasure to their coming for they are to the water what swallows are to the air. They fill a place that no other bird can fill, and leave a painful void when they depart.

Аввотт. Birdland Echoes. ${ }^{28}$

Their flight is quite peculiar. With one quick stroke of the wings they can propel themselves a long distance, and, by repeating at intervals the single vibration, they appear to be floating in air, as with motionless wing they 


\section{Sandpiper, Spotted}

speed along close to the water. When standing on the ground they have a ludicrous trick of ducking the head and jerking the body, the purpose of which is quite unaccountable, a habit that has given them the expressive, if not elegant, sobriquet of "teetertail," or "tip-up."

\section{Parkhurst. The Birds' Calendar. ${ }^{31}$}

The birds of this species have been so wantonly and mercilessly hunted by gunners of all ages, that they have become extremely shy, and have lost all confidence in man. Yet if they were harbored, and protected from annoyance and danger, they would grow tame and confiding, and our fields and gardens would be full of them. A brood of them . . . would be indefatigable hunters of insects in pastures and tilled lands. . . . These little birds are incapable of doing any mischief, even if there were fifty of them on every farm. They take no fruit; they do not bite off the tops of tender herbs, like poultry; and they are interesting in their ways.

FLAGG. A Year With the Birds. ${ }^{25}$

CaLl-Note:

A sharp "weet-weet--weet-weet." Chapman. "Wet-feet--wet-feet." Van DYke.

\section{The Sandpiper}

Across the narrow beach we flit,

One little sandpiper and I;

And fast I gather, bit by bit,

The scattered driftwood, bleached and dry. 


\section{Sandpiper, Spotted}

The wild waves reach their hands for it, The wild wind raves, the tide runs high, As up and down the beach we flit,-One little sandpiper and I.

Above our heads the sullen clouds

Scud black and swift across the sky;

Like silent ghosts in misty shrouds

Stand out the white light-houses high.

Almost as far as eye can reach

I see the close-reefed vessels fly, As fast we flit along the beach,--

One little sandpiper and I.

I watch him as he skims along

Uttering his sweet and mournful cry;

He starts not at my fitful song,

Or flash of fluttering drapery.

He has no thought of any wrong;

He scans me with a fearless eye.

Staunch friends are we, well-tried and strong,

The little sandpiper and I.

Comrade, where wilt thou be to-night

When the loosed storm breaks furiously?

My driftwood fire will burn so bright!

To what warm shelter canst thou fly?

I do not fear for thee, though wroth

The tempest rushes through the sky:

For are we not God's children both, Thou, little sandpiper, and I?

Celia Thaxter. 


\section{SAPSUCKER, YELLOW-BELLIED}

Though the sapsucker has to be content with a mottled black and white coat, he wears, besides a red cap, a crimson frontlet, a bib-shaped piece of crimson satin fastened close under his chin, and bordering this a circlet of black satin, below which, and falling to his feet, is his pale yellow robe. . . He spends much of his time riddling live trees with squarish holes, to which he returns to drink the oozing sap and feast upon the insects that gather.

Florence A. Merriam. Birds Through an Opera Glass. ${ }^{2}$

\section{SPARROW, CHIPPING. HAIR-BIRD}

$\mathrm{He}$ is called "hair-bird" because he lines his nest with horse or cow hair, and when you think of the close observation and industry it takes to find this hair you will recognize not only the power of inherited habit, but the fitness of the name.

Florence A. Merriam. Birds Through an Opera Glass. ${ }^{2}$

In this bird we have an instance of a creature winning its way to our regard without any effort on its part other than the general loveliness of its disposition. It performs no great feats of flight like the swallow; it builds no conspicuous nest like the oriole; it sings but the simplest ditty of all our birds; but it does come to our doors; it does salute us with a cheerful song; it offers to be friendly and so wins our hearts.

Аввотт. Birdland Echoes. ${ }^{28}$ 


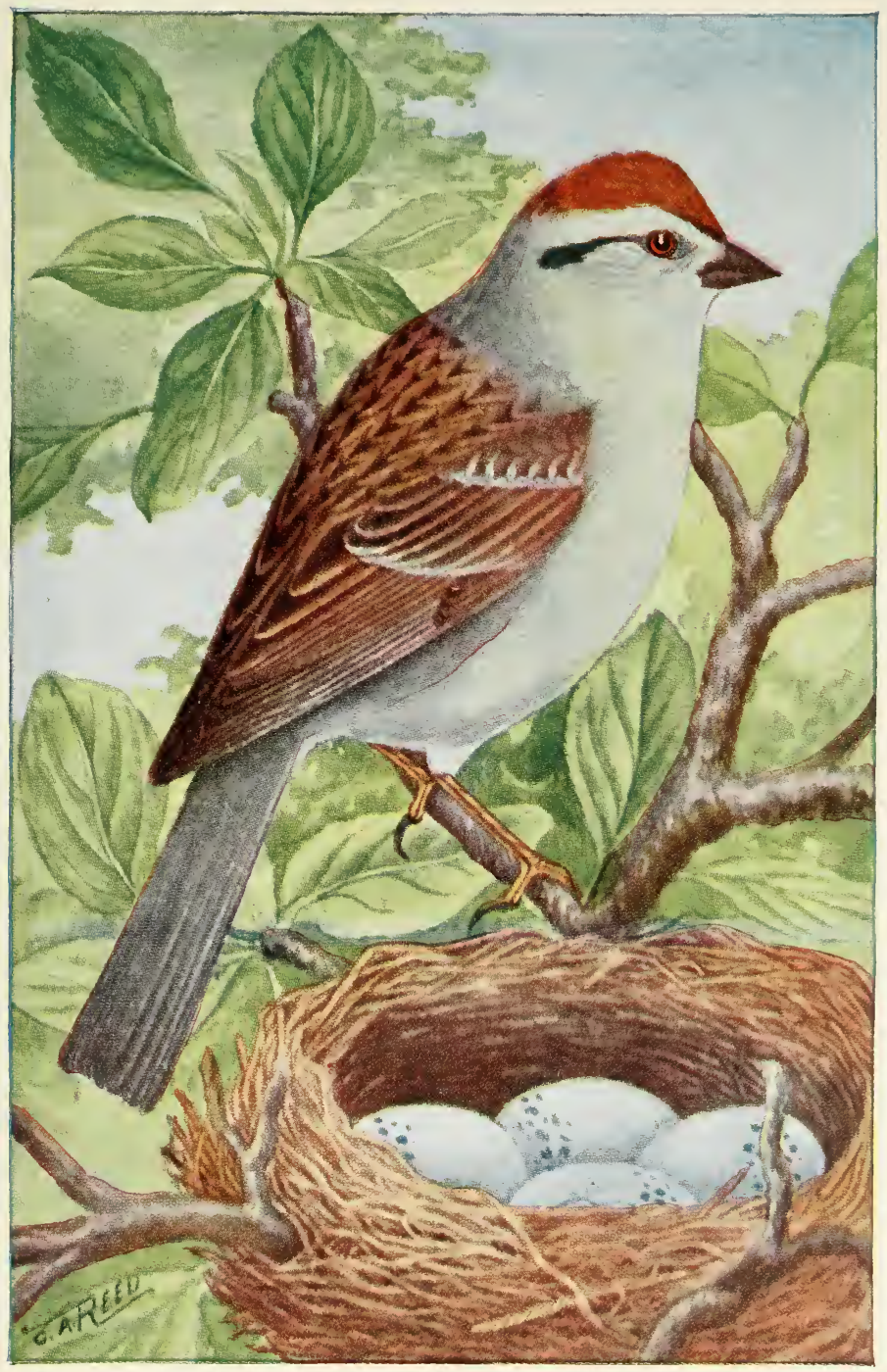





\section{Sparrow, Chipping. Hair-Bird}

The ordinary note is a single chip; besides this there is a long, monotonous trill, somewhat like a watchman's rattle.

\section{A. Willcox. Common Land Birds of New England. ${ }^{29}$}

His voice is no mean accompaniment to the general chorus which may be heard on every still morning before sunrise during May and June. His continued trilling note is to this warbling band like the octave flute, as heard in a grand chorus of artificial instruments. The voices of numbers of his species, which are the first to be heard and the last to become silent in the morning, serve to fill up the pauses in this sylvan anthem like a running accompaniment in certain musical compositions.

FLAGG. A Year With the Birds. ${ }^{25}$

Without a song, save in its heart, from twig and fence the live-long summer, it has done its best with its one note--its one talent--to bring cheer into the world; and justice demands that it be judged by its effort rather than by its accomplishment.

Parkhurst. The Birds' Calendar. ${ }^{31}$

\section{SPARROW, FIELD}

Its bright rufous color, the absence of spots on its breast, and especially its flesh-colored bill, are the best field-marks of this misnamed sparrow. He is not a true field sparrow, but prefers old pastures dotted with clumps of bushes or young cedars. There is something winning in his 


\section{Sparrow, Field}

appearance; he seems such a gentle, innocent, dove-like little bird. His song is in keeping with his character, being an unusually clear, plaintive whistle, sweeter to the lover of birds' songs than the voice of the most gifted songstress.

Chapman. Handbook of Birds. ${ }^{21}$

\section{Song:}

Fe-o, fe-o, fe-o, few, few, few, fee, fee, fee.

BurRoughs.

A fine strain, beginning with two or three high, sustained, piercing notes, then running into a succession of similar, more rapid notes, all in a minor key, and often running down, or occasionally up the chromatic scale.

Selected.

\section{The Field Sparrow}

A bubble of music floats

The slope of the hillside over;

A little wandering sparrow's notes;

And the bloom of yarrow and clover,

And the smell of sweet-fern and the bayberry leaf,

On his ripple of song are stealing;

For he is a chartered thief,

The wealth of the fields revealing.

One syllable, clear and soft

As a raindrop's silvery patter,

Or a tinkling fairy bell, heard aloft,

In the midst of the merry chatter 


\section{Sparrow, Field}

Of robin and linnet and wren and jay,--

One syllable, oft repeated:

He has but a word to say,

And of that he will not be cheated.

The singer I have not seen;

But the song I arise and follow

The brown hills over, the pastures green,

And into the sunlit hollow.

With a joy that his life unto mine has lent,

I can feel my glad eyes glisten,

Though he hides in his happy tent,

While I stand outside and listen.

This way would I also sing,

My dear little hillside neighbor!

A tender carol of peace to bring

To the sunburnt fields of labor

Is better than making a loud ado;

Trill on, amid clover and yarrow!

There's a heart-beat echoing you,

And blessing you, blithe little sparrow!

LUCy LaRcom.

\section{SPARROW, FOX}

The first sight of the bird is surely a memorable experience. What with his large size, his striking fox-colored back and tail, together with the remarkable combination of slate-gray and fox on his head, he seems a new, strange creature.

Florence A. Merriam. Birds of Village and Field. ${ }^{1}$ 


\section{Sparrow, Fox}

He has a peculiar method of scratching the ground, not like a hen, with one foot at a time, but somehow with both at once, in a little spasm.

\section{Parkhurst. The Birds' Calendar. ${ }^{31}$}

. . . The russet groundbird bold With both slim feet at once will lightly rake the mold.

SiLl.

Not the least important of its prepossessing features is its conspicuous good-nature, a hail-fellow, well met, fraternizing at once with chickadees, snow-birds, whitethroats, and any others of peaceable disposition.

Its musical ability . . . . surpasses all other sparrows in fine modulation and a peculiarly full, luscious and flutelike quality of tone, tinged with a delicious plaintiveness. It is like a wild spring flower. If its notes should fall to the ground and take root, they would certainly spring up as hepaticas or something of the sort.

PARkhurst. The Birds' Calendar. ${ }^{31}$

\section{SPARROW, GRASSHOPPER}

Its fine insect-like notes give it the name of grasshopper sparrow. They may be written pit-tuck, zee-e-e-e-e-e-e-e-e.

Its usual perch, when singing, is a fence rail; and it does not often seek an elevated position.

Chapman. Handbook of Birds. ${ }^{21}$ 


\section{SPARROW, SONG}

Generally you will find him on or near the ground at the border of some undergrowth, and if there be water near by, preferably a meadow brook, his presence is assured. When flushed, he will doubtless make for the nearest thicket, "pumping" his tail in describing his somewhat jerky flight. Equally diagnostic is the bird's spotted breast with the one larger spot in its center.

Chapman. Bird Life. ${ }^{22}$

The first sound of the song sparrow falls on the senses like a bit of unexpected sunshine in a stormy day, and raises the temperature of one's feelings many degrees, for in a twinkling it breaks the spell of winter.

\section{PARkhurst. The Birds' Calendar. ${ }^{31}$}

Some birds are poets and sing all summer. They are the true singers. Any man can write verses in the love season. . . . . We are most interested in those birds that sing for the love of music and not of their mates; who meditate their strains and amuse themselves with singing; the birds whose strains are of deeper sentiment.

THOREAU.

Their song bears the test of every day; for while it is not brilliant, it has all the sweetness of the gentle bird's own simple nature, and heard far from home stirs chords that the more brilliant strangers do not touch. Furthermore the student who is interested in noting bird songs, will find the song sparrow's well worth study, for it varies 


\section{Sparrow, Song}

remarkably. Fifteen varieties of its song have been noted in one week, and the same individual often has a number of tunes in his repertoire.

Florence A. Merriam. Birds of Village and Field. ${ }^{1}$

You will find that he repeats one strain for perhaps a dozen times, without the change of a note; then suddenly he comes out with a song entirely different. This second song he will in turn drop for a third and so on. The bird acts, for all the world, as if he were singing hymns, of so many verses each, one after another.

Torrey. Every Day Birds. ${ }^{18}$

The sparrow . . . assured all the plain Quakers within hearing that he was a good Pres-pres-pres-prespres-by-te-ri-an.

Аввотт. Birds About Us. ${ }^{27}$

The song sparrow is said to be imitated in New Bedford thus: "Maids, maids, maids,--hang on your tea-kettle - - ettle, ettle, ettle, ettle.

THOREAU.

I thought the sparrow's note from heaven,

Singing at dawn on the alder bough;

I brought him home, in his nest, at even;

He sings the song, but it cheers not now,

For I did not bring home the river and sky;--

He sang to my ear,--they sang to my eye.

EMERson. 


\section{Sparrow, Song}

\section{The Song Sparrow}

Sunshine set to music!

Hear the sparrow sing!

In his note is freshness

Of the new-born Spring:

In his trill delicious

Summer overflows--

Whiteness of the lily, Sweetness of the rose.

Splendor of the sunrise, Fragrance of the breeze, Crystal of the brooklet Trickling under trees, Over moss and pebbles-Hark! you have them all Prophesied and chanted In the sparrow's call.

\section{Song Sparrow}

A few notes, three or four, Repeated o'er and o'er

In low soft, liquid strains, Make all thy hymn of praise, Sing all love's tender lays, Sing even love's sweet pains.

Thy fond mate sitting near Is glad as I to hear

That triumph of thine art; 


\section{Sparrow, Song}

Just that same song of thine,

Sung over line by line,

Won her grandmother's heart.

Selected.

\section{The Song Sparrow}

He does not wear a Joseph's coat

Of many colours, smart and gay;

His suit is Quaker brown and gray,

With darker patches at his throat.

And yet of all the well-dressed throng

Not one can sing so brave a song.

It makes the pride of looks appear

$A$ vain and foolish thing to hear

His "Sweet-sweet-sweet-very merry cheer."

I like the tune, I like the words;

They seem so true, so free from art,

So friendly, and so full of heart,

That if but one of all the birds

Could be my comrade everywhere,

My little brother of the air,

This is the one I'd choose, my dear, Because he'd bless me, every year, With "Sweet-sweet-sweet-very merry cheer."

Henry Van Dyke. 


\section{Sparrow, Song}

\section{The Myth of the Song Sparrow}

His mother was the Brook, his sisters were the Reeds, And they every one applauded when he sang about his deeds.

His vest was white, his mantle brown, as clear as they could be,

And his songs were fairly bubbling o'er with melody and glee.

But an envious Neighbor splashed with mud our Brownie's coat and vest,

And then a final handful threw that stuck upon his breast. The Brook-bird's mother did her best to wash the stains away,

But there they stuck, and, as it seems, are very like to stay,

And so he wears the splashes and the mud blotch as you see,

But his songs are bubbling over still with melody and glee. Ernest Thompson Seton.

"Wood Myth and Fable."-Century Company, 1905. This poem is printed by special permission of the author.

\section{SPARROW, TREE}

Tree sparrows wear a small black dot on the center of their otherwise unmarked breasts, a badge which will aid in their identification.

I like to see them feasting on the seed stalks above the crust, and to hear their chorus of merry, tinkling notes, like sparkling frost crystals turned to music. Too-la-it, too-la-it, each one calls.

Chapman. Handbook of Birds. ${ }^{21}$ 


\section{Sparrow, Tree}

This bird has ever been a favorite of mine, not because there is so much of him as so much of them. It is a case where one is not as good as a hundred, but just the opposite, and a hundred, fortunately, are easier found than one. Nuttall speaks of two or three singing together. I have heard a full chorus, and it is then music that makes you forget the "deadness" of the season.

\section{Аввотт. Birds About Us. ${ }^{27}$}

The tree sparrow is a striking illustration of the good done by seed-eating birds, for Professor Beal has calculated that in Iowa alone this little bird destroys eight hundred and seventy-five tons of noxious weed-seeds every year.

Florence A. Merriam. Birds of Village and Field. ${ }^{1}$

\section{SPARROW, VESPER. BAY-WINGED BUNTING}

There are few grassy fields, I imagine, where this bird is not found, and you are not likely to mistake it, for it shows two white feathers in its tail when flying. It is a ground bird the greater part of each day, and chirps when startled, like any other "chippy"; but it is a master musician for all that, and, singing at or after sundown, has been aptly called the vesper-sparrow.

\section{Аввотт. Birds About Us. ${ }^{27}$}

The vesper sparrow likes a drier field than the song sparrow, and is especially noticeable for the trick of running along the path or the road directly in front of the traveler.

Torrer. Every Day Birds. ${ }^{18}$ 


\section{Sparrow, Vesper. Bay-Winged Bunting}

Sometimes when started from the nest, the female simulates lameness with remarkable dexterity, so as very readily to draw off the attention of her enemies or intruders.

\section{Nuttall's Ornithology. ${ }^{26}$}

It is impossible to satisfactorily describe this song. It resembles that of the song sparrow, but is finer and wilder. It opens with one low note, followed by two higher ones, while the song sparrow begins with three notes, all of the same kind.

Chapman. Bird Life. ${ }^{22}$

On every side, near and remote, from out the short grass which the herds are cropping, the strain rises. Two or three long, silver notes of peace and rest, ending in some subdued trills and quavers. . . . Such unambitious, quiet, unconscious melody! It is one of the most characteristic sounds in Nature. The grass, the stones, the stubble, the furrow, the quiet herds, and the warm twilight among the hills are all subtilely expressed in this song.

Burroughs. Wake Robin. ${ }^{5}$

How different from the ecstatic outburst of the song sparrow! Pensive, but not sad, its long-drawn silvery notes continue in quavers that float off unended like a trail of mist. The song is suggestive of the thoughts that must come at evening to some New England saint of humble station after a well-spent, soul-uplifting day.

Neltje Blanchan. Bird Neighbors. ${ }^{23}$ 
Sparrow, Vesper. Bay-Winged Bunting

\section{The Vesper Sparrow}

It comes from childhood's land, Where summer days are long And summer eves are bland,-

A lulling good-night song.

Upon a pasture stone, Against the fading west,

A small bird sings alone,

Then dives and finds his nest.

The evening star has heard, And flutters into sight;

O childhood's vesper-bird, My heart calls back, good-night.

Еdith M. Thomas.

\section{SPARROW, WHITE-CROWNED}

Sometimes one of these distinguished-looking birds will be discovered in a flock of white-throats. You can tell him from his cousins at a glance, because he has not the "white patch under his chin. His crown serves still further to distinguish him. It is as striking as a soldier's cap. Moreover he attracts attention by his general bearing which is unmistakably that of an aristocrat. . . . . . Mr. Burroughs is enthusiastic over the white-crown. He says: "He is the rarest and most beautiful of the sparrow kind. He is crowned as some hero or victor in the games."

Florence A. Merriam. Birds of Village and Field. ${ }^{1}$ 


\section{SPARROW, WHITE-THROATED. PEABODY BIRD}

In a family not distinguished for good looks, the whitethroated sparrow is conspicuously handsome, especially after the spring moult. The black, white and yellow markings on his head are now clear and beautiful. His figure is plump and aristocratic.

Neltje Blanchan. Bird Neighbors. ${ }^{23}$

His song consists of "two long clear notes followed by two or three triplets." It has been variously translated as "Old-Sam-Peabody-Peabody-Peabody"; "Swe-e-et Cana-da, Can-a-da, Can-a-da"; "All day, whit-tle-ing, whit-tleing, whit-tle-ing"; and William Hamilton Gibson tells of a perplexed husbandman, Peverly by name, who, hesitating at his choice of crops, heard him advise, "Sow wheat, Pev-er-ly, Pev-er-ly, Pev-er-ly."

\section{The Sing-Away Bird}

Have you ever heard of the Sing-away bird,

That sings where the Runaway river

Runs down with its rills from the bald-headed hills

That stand in the sunshine and shiver?

"Oh, sing! sing-away! sing-away!"

How the pines and the birches are stirred

By the trill of the Sing-away bird!

And the bald-headed hills, with their rocks and their rills,

To the tune of his raptures are ringing;

And their faces grow young, all the gray mists among,

While the forests break forth into singing.

"Oh, sing! sing-away! sing-away!"

And the river runs singing along;

And the flying winds catch up the song. 


\section{Sparrow, White-Throated. Peabody Bird}

'Twas a white-throated sparrow, that sped a light arrow

Of song from his musical quiver,

And it pierced with its spell every valley and dell

On the banks of the Runaway river.

"Oh, sing! sing-away! sing-away!"

The song of the wild singer had

The sound of a soul that is glad.

And, beneath the glad sun, every glad-hearted one

Sets the world to the tune of his gladness:

The swift rivers sing it, the wild breezes wing it,

Till Earth loses thought of her sadness.

"Oh, sing! sing-away! sing-away!"

Oh, sing, happy soul, to joy's Giver,-

Sing on, by Time's Runaway River!

LuCy LaRcom.

\section{SWALLOW, BANK. SAND MARTIN}

This swallow is the only one of the family which still retains its old nesting habits, scorning the devices provided by man which have proved so attractive to its brothers.

They fly much like other swallows, but never wander far from their nesting-places. Their nests are placed at the end of burrows dug out by the birds in sand-banks. The vicinity of water is usually preferred, but railway and road cuttings are sometimes chosen. The ground must be such as will not cave in.

M. A. Willcox. Common Land Birds of New England. ${ }^{29}$ 


\section{Swallow, Bank. Sand Martin}

We draw an invidious distinction when we say that the bank swallow is prettier than the cliff swallow or otherwise set one above another. They are all as pretty as pictures, and those that are not brilliant in color possess unequalled grace, for a swallow in the air is the purest poetry of motion; it is as if it and the air were one. You cannot take the bird from the sky without dimming all its lustre. It is not strange that the Delaware Indians called these birds "feathered spirits."

Аввотт. Birdland Echoes. ${ }^{28}$

\section{The Origin of Bank Swallows}

AN ESKIMO STORY.

Once upon a time, some exceedingly wise children were playing on the edge of a cliff near their native village. Suddenly while building mud houses, they were changed into swallows. Yet with all their change of body and manner of living, they remembered their last occupation as children and still made houses on the cliff.

The memory of that last hour of childish play has been given to all their descendants, for, even to this day they come to a cliff to build their nests of mud.

AdAPted.

\section{SWALLOW, BARN}

Barn swallows take first rank among a family of birds famous for their power of flight. While their relatives are circling about feeding on insects in the air above, they capture their prey nearer the ground, skimming low over the fields, turning quickly to right or left, up or down, and pursuing their erratic course with marvelous ease and grace.

Chapman. Handbook of Birds. ${ }^{21}$ 


\section{Swallow, Barn}

As he sweeps near us, the rich metallic sheen of his back is well seen; and as he flies up to a telegraph wire, his long forked tail and deep chocolate breast identify him beyond question.

Florence A. Merriam. Birds of Village and Field. ${ }^{1}$

None of the swallows have a song, but their feelings effervesce in lively clinking notes that are not unmusical. They are in less need of a song than most other birds, for they can work off their feelings through their dashing and tireless flight.

Parkhurst. The Birds' Calendar. ${ }^{31}$

The young often utter a series of twitters, which resemble the laugh of a tickled child.

мinot. Land and Game Birds. ${ }^{20}$

Wheeling about our barns and houses, skimming over the fields, its bright sides flashing in the sunlight, playing "cross-tag" with its friends at evening, when the insects too are on the wing, gyrating, darting and gliding through the air, it is no more possible to adequately describe the exquisite grace of the swallow's flight, than the glistening buff of his breast. This swallow is peculiarly American.

Neltje Blanchan. Bird Neighbors. ${ }^{23}$

The dandelion tells me when to look for the swallow. Burroughs. Wake Robin. ${ }^{5}$ 


\section{Swallow, Barn}

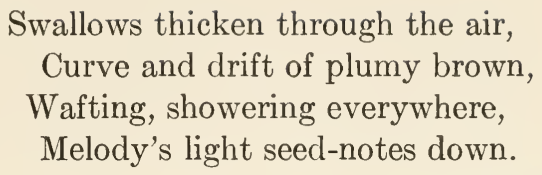

LUCy LARCOM.

The thin-winged swallow, skating on the air.

Gibson.

\section{The Swallow}

At play in April skies that spread Their azure depths above my head As onward to the woods I sped,

I heard the swallow twitter;

$\mathrm{O}$ skater in the fields of air

On steely wings that sweep and dare, To gain these scenes thy only care,

Nor fear the winds are bitter.

Ah, well I know thy deep-dyed vest, Thy burnished wing, thy feathered nest, Thy lyric flight at love's behest,

And all thy ways so airy;

Thou art a nursling of the air,

No earthly food makes up thy fare

But soaring things both frail and rare,

Fit diet of a fairy.

John Burroughs. 


\section{SWALLOW, CLIFF or EAVE}

The cliff swallows, as their name implies, naturally fix their queer bottle-nosed nest to the perpendicular faces of rocks and hard embankments; and have latterly acquired the name of eave swallows from the circumstance that they have readily availed themselves of the eligible nesting sites afforded by the walls of houses under shelter of the eaves.

\section{Stearns. New England Bird Life. ${ }^{30}$}

They sometimes extend nearly across the whole side of a roof, resembling in some degree a long row of hornets' nests. They are made of clay and mud without intermixture of other substances ("bricks without straw"), and lined with grass and feathers.

\section{FLAGG. A Year With the Birds. ${ }^{25}$}

The light rump and whitish forehead easily distinguish it from the other swallows.

There is no evil blended with the many benefits swallows confer upon man. They destroy the insects that annoy his cattle, injure his fruit trees, sting his fruit or molest his cattle.

BREWER.

. . the swallow of the mud nest, He with blue and chestnut breastplate, He with snow upon his forehead.

Bolles. Chocorua's Tenants. ${ }^{19}$ 


\section{Swallow, Cliff or Eave}

\section{The Swallows}

Gallant and gay in their doublets gray,

All at a flash like the darting of flame,

Chattering Arabic, African, Indian-

Certain of springtime, the swallows came!

Doublets of gray silk and surcoats of purple, And ruffs of russet round each little throat, Wearing such garb they had crossed the waters, Mariners sailing with never a boat.

Edwin ARnold.

\section{SWALLOW, TREE or WHITE-BELLIED}

These swallows usually announce spring to the people of Boston and its vicinity in the first week of April; but after their arrival they are sometimes obliged, when discouraged by the cold, to retreat temporarily southward to a warmer latitude. As our ancestors long since discovered this fact in relation to their swallows, they have handed down to us th' wise proverb that "One swallow does not make a summer."

Mınoт. Land and Game Birds. ${ }^{20}$

Their predilection for the borders of lakes and ponds led some of the ancient writers to believe that swallows retired to the bottom of the water during the winter; and some fishermen on the coast of the Baltic pretended to have taken them up in their nets in large knots, clinging together by the bills and claws in a state of torpidity.

Nuttall's Ornithology. ${ }^{26}$ 


\section{Swallow, Tree or White-Bellied}

Their white breasts flash in the sunlight, and it is only when they dart near you, and skim close along the surface of the water, that you discover their backs to be not black, but rich dark green, glossy to iridescence.

\section{Neltje Blanchan. Bird Neighbors. ${ }^{23}$}

They are more quarrelsome and less sociable in the breeding season than the barn swallow. In the spring their protracted, angry contentions and rapid chatter are often heard in the air.

\section{Nuttall's Ornithology. ${ }^{26}$}

Unlike most swallows, they vary their insect diet with berries, being especially fond of bay-berries.

Florence A. Merriam. Birds of Village and Field. ${ }^{1}$

The tree swallows are passing through a transition period in their history. Some accept the houses or boxes erected by man as substitutes for the holes in trees or stumps which others still use.

Chapman. Handbook of Birds. ${ }^{21}$

\section{SWIFT, CHIMNEY}

No one ever saw him sitting on a perch or walking on the ground. In fact, his wings are so long, and his legs so short and weak, that if he were to alight on the ground, he would probably never be able to rise in the air again.

Torrey. Every Day Birds. ${ }^{18}$ 


\section{Swift, Chimney}

One might infer that they had contracted their sootbrown color by contact with chimneys for several generations, until it became ingrained.

They are well named "swifts," as they are not surpassed, and are rarely equalled, by any other birds in their power of flight, sometimes covering a thousand miles in twentyfour hours.

Parkhurst. The Birds' Calendar. ${ }^{31}$

Their wings are developed till they look like strips of cardboard more than |bunches of feathers. . . . . On the other hand, their feet, like those of Chinese ladies, are so little used that they are small and weak. They serve merely as picture hooks, for the birds hook them over the edge of the nest or into a crack in the chimney, and proceed to go to sleep hanging like pictures on a wall. . . . The tail comes in to act as a prop, being bent under the bird to brace against the wall. Doubtless, by this habit, the end of the tail has gradually lost its feathery character, the webbing being worn off, till now only the stiff, bone-like quills of the feathers remain. These they use like little awls, to stick into the bricks.

Florence A. Merriam. Birds of Village and Field. ${ }^{1}$

Major Bendire says that few birds are more devoted to their young than the chimney swift, a case being recorded where the parent was seen to enter a chimney in a burning house, even after the entire roof was a mass of flames, preferring to perish with its offspring rather than forsake them.

Florence A. Merriam. Birds of Village and Field. ${ }^{1}$ 


\section{TANAGER, SCARLET}

That bit of bright scarlet on yonder dead hemlock, glowing like a live coal against the dark background, seeming almost too brilliant for the severe northern climate, is the scarlet tanager. I almost fear he will kindle the dry limb on which he alights.

Burroughs. Wake Robin. ${ }^{5}$

Seen against the leafy background, light seems to radiate from his glowing feathers.

Chapman. Bird Life. ${ }^{22}$

We are first guided to him by his call and song. They are peculiar and both have a rare woods flavor. The call is a rapidly uttered chip-chirr. The song is a loud, cheery, rhythmical carol, suggesting the song of the robin.

Florence A. Merriam. Chapman's Handbook of Birds. ${ }^{21}$

Mounting to the topmost branch, often of a dead or partially dead tree, he sings, "Look-up, way-up, look-atme, tree-top."

Chapman. Bird Life. ${ }^{22}$

The redbird spread his sable wing,

And showed his side of flame.

EMERSon.

\section{THRASHER, BROWN. BROWN THRUSH}

He may be recognized at a considerable distance, from his habit of flirting his tail while perched, much after the fashion of the catbird. And if one gets a nearer view, 


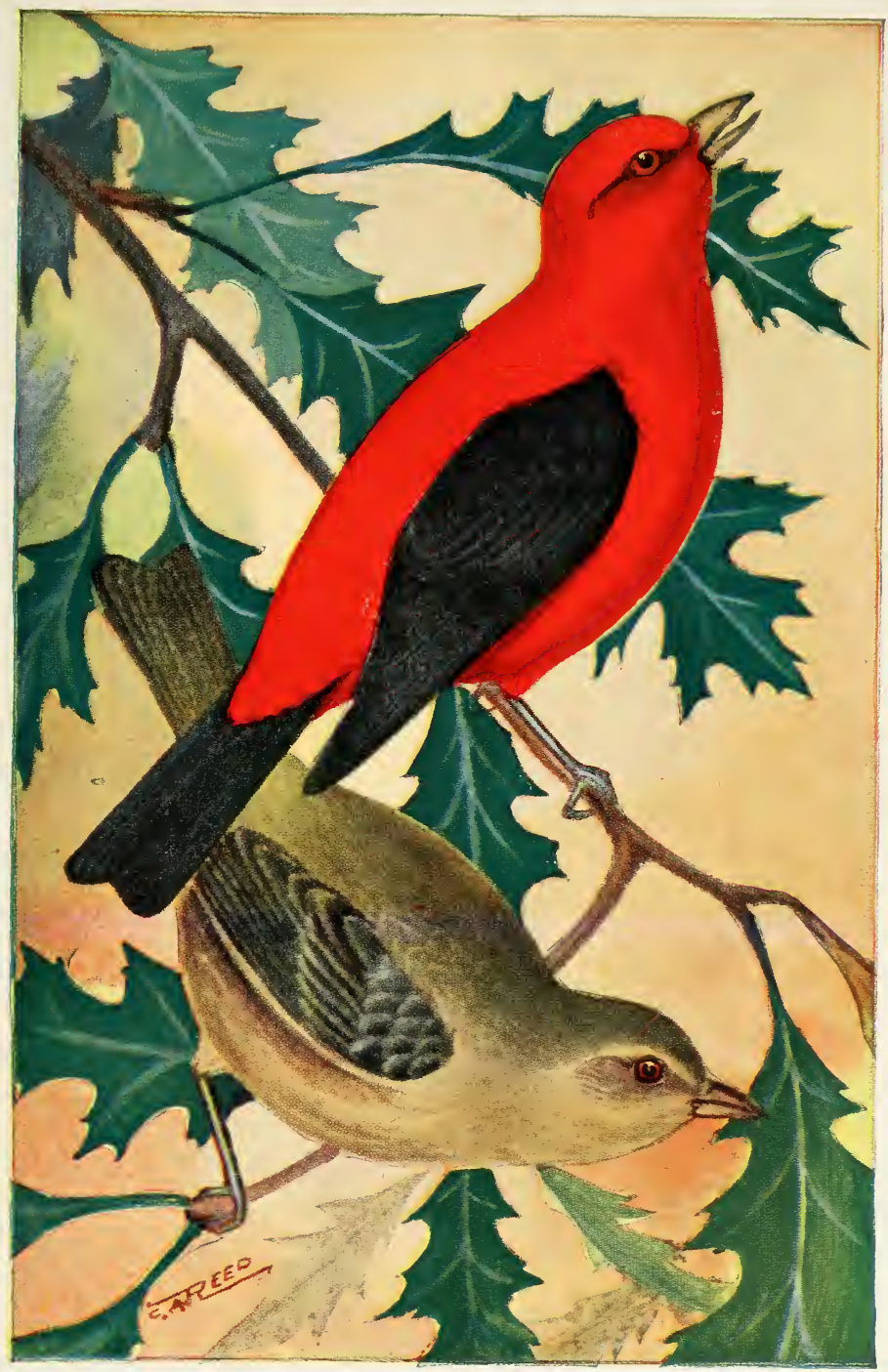





\section{Thrasher, Brown. Brown Thrush}

he may be distinguished from all other thrush-like birds by the two white wing-bars and the extraordinarily long tail.

M. A. Willcox. Common Land Birds of New England. ${ }^{29}$

$\mathrm{He}$ is an active, suspicious bird, who does not like to be watched, and expresses his annoyance with an unpleasant kissing note or sharply whistled wheeu.

Chapman. Handbook of Birds. ${ }^{21}$

His song is a sort of recitative, often resembling spoken words rather than musical notes, many of which are short and guttural. .... An ingenious shoemaker ... . gave me the following words: "Look up, look up,-Glory to God, glory to God,-Hallelujah, Amen, Videlicet."

FLAGG. A Year With the Birds. ${ }^{25}$

While you are planting the seed, he cries, "Drop it, drop it,-cover it up, cover it up,--pull it up, pull it up pull it up."

Thoreau.

When he sings he takes the very top of a tree, although usually it is not a tall one. There he stands by the halfhour together, head up and tail down, pouring out a flood of music; sounds of all sorts, high notes and low notes, smooth notes and rough notes, all jumbled together in the craziest fashion, as if the musician were really beside himself. It is a performance worth buying a ticket for and going miles to hear.

TORRey. Every Day Birds. ${ }^{18}$ 


\section{Thrasher, Brown. Brown Thrush}

The brown thrasher calls half furtively, half archly, from the tree-top back in the bushy pastures: "Croquet, croquet, hit it, hit it, come to me, come to me, tight it, tight it, you're out, you're out."

\section{Burroughs. Pepacton. ${ }^{9}$}

Cherruwit, cherruwit, go ahead, go ahead, give it to him, give it to him, etc.

Thoread. Excursions. ${ }^{17}$

As affording some light on the popular name of "thrasher," I might mention the remark of a certain matter-of-fact rustic who answered my query for enlightenment upon the subject-_. "Some fokes sez it's becuz he's aliz a-thrashin' around so in the bushes,'n 'others sez it's becuz he's ferever tellin' uv 'em to 'thrash it, thrash it!' But thet's all puppycut; he sez ennything you like."

Gibson. Strolls by Starlight and Sunshine. ${ }^{33}$

The wise thrush, he sings each song twice over,

Lest you fear he never could recapture

That first fine careless rapture.

SeleCted.

\section{The Brown Thrush}

"There's a merry brown thrush sitting up in the tree, He's singing to me! He's singing to me!" And what does he say, little girl, little boy?

"Oh, the world's running over with joy!

Don't you hear? don't you see?

Hush! Look! In my tree

I'm as happy, as happy can be!" 


\section{Thrasher, Brown. Brown Thrush}

And the brown thrush keeps singing, "A nest do you see,

And five eggs, hid by me in the juniper tree?

Don't meddle! don't touch! little girl, little boy,

Or the world will lose some of its joy!

Now I'm glad, now I'm free!

And I always shall be,

If you never bring sorrow to me."

So the merry brown thrush sings away in the tree,

To you and to me, to you and to me;

And he sings all the day, little girl, little boy,

"Oh, the world's running over with joy!

But long it won't be,

Don't you know? don't you see?

Unless we are as good as can be!"

LUCy LARCOM.

\section{THRUSH, HERMIT}

As the name implies, it is the most secretive of the thrushes in its habits, and would be little known were it not so abundant and so widely dispersed during the migrations.

Stearns. New England Bird Life. ${ }^{30}$

In the middle and eastern states, during the period of song, it is found only in the deepest and most remote forests, usually in damp and swampy localities. On this account the people in the Adirondack region call it the "Swamp Angel."

Burroughs. Wake Robin. ${ }^{5}$ 


\section{Thrush, Hermit}

The hermit has a distinguishing reddish tail, which it raises and lowers as it gives its characteristic call of chuck.

Its song is one for which many of nature's devotees make long pilgrimages; and to my mind it excels that of any bird I have ever heard, being, above all others, serene and uplifting.

Florence A. Merriam. Birds of Village and Field. ${ }^{1}$

In full song his voice is rich and sonorous; and a softer tone, which I heard soon after his arrival, was like the finest thread of pure gold.

Parkhurst. The Birds' Calendar. ${ }^{31}$

It is perhaps more of an evening than a morning hymn, though I hear it at all hours of the day. It is very simple, and I ean hardly tell the secret of its charm. "O spheral, spheral!" he seems to say: "O holy, holy! O clear away, clear away! O clear up, clear up!" interspersed with the finest trills and the most delicate preludes. . . . . It suggests no passion or emotion,- - nothing personal,but seems to be the voice of that calm, sweet solemnity one attains to in his best moments.

Burroughs. Wake Robin. ${ }^{5}$

Unrivaled one, the hermit-thrush, Solitary, singing in the west.

Selected.

Then in that solemn hour I hear

A hymn that comes so sweet and clear,

So pure a tone, it seems to be

A bit of heaven's minstrelsy.

Selected. 



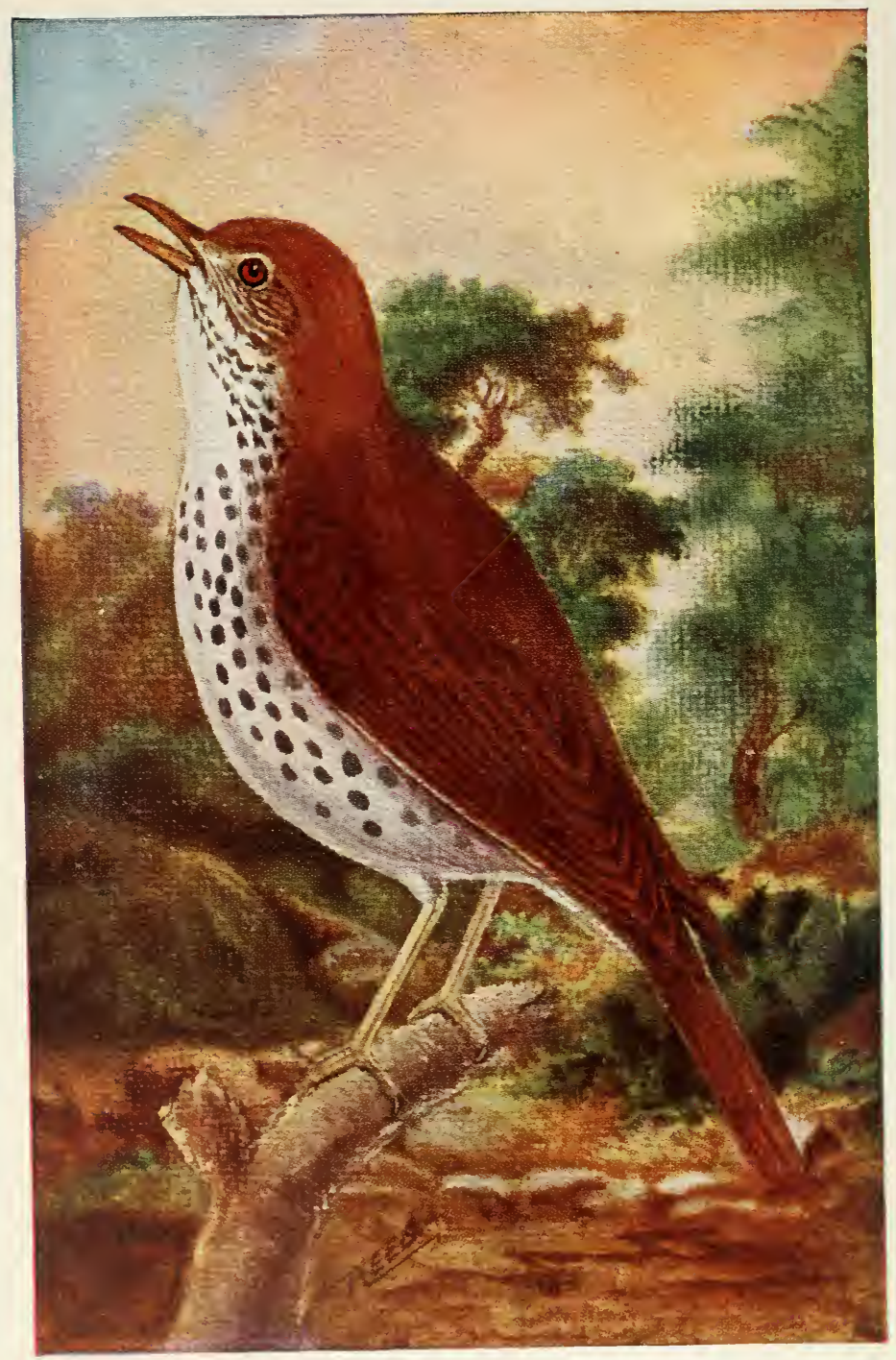




\section{THRUSH, WOOD}

Its large size, heavily spotted breast and the rich golden brown of its back, brightest on its head, distinguish it from the other thrushes.

Florence A. Merriam. Birds of Village and Field. ${ }^{1}$

$\mathrm{He}$ is truly a royal minstrel, and considering his liberal distribution throughout our Atlantic seaboard, perhaps contributes more than any other bird to our sylvan melody.

Burroughs. Wake Robin. ${ }^{5}$

His calm, restful song rings through the woods like a hymn of praise rising pure and clear from a thankful heart. It is a message of hope and good cheer in the morning, a benediction at the close of day.

The flute-like opening notes, "Come to me," are an invitation to his haunts; a call from Nature to yield ourselves to the ennobling influences of the forest.

Chapman. Handbook of Birds. ${ }^{21}$

The wood thrush, having mounted to a perch so high that his outbursts of heavenly music shall not be confined to earth or lost in the surrounding shrubbery, pours out such a melody that he seems at every utterance "to be endeavoring to recall his very soul, that fled to heaven on the winged notes of his last liquid melody."

Мinot. Land and Game Birds. ${ }^{20}$

There may be sweeter sounds the wide world over, but he is blessed that has heard this one.

Аввотт. Birds About Us. ${ }^{27}$ 


\section{Thrush, Wood}

He willy willy-ha willy willy-O willy $\mathrm{O}$.

EMERSON.

The bell of the wood thrush.

Gibson.

Hush!

'Tis the first melting gush,

Then slowly-

In notes by all of earth untaught,

Each tone it seems a liquid thought,

He pours rich meanings all unsought,

Most holy.

Selected.

\section{VEERY. WILSON'S THRUSH. TAWNY THRUSH}

This is to be distinguished from the other thrushes by the uniform color of the upper parts, the absence of an eye-ring and the faintly spotted breast.

They can run over the ground with rapidity, but in the woods they usually poke about quietly among the pine needles and dead leaves, where they can find the insects on which they feed. . . . When disturbed, while thus busied, they generally fly to a bush near the spot, and sit there quite motionless, occasionally uttering their chirp, until it seems safe to return to their interrupted occupation.

Minot. Land and Game Birds. ${ }^{20}$ 
Veery. Wilson's Thrush. Tawny Thrush

Until this little bird arrives, I feel as the audience do at a concert before the chief singer appears, while the other performers are vainly endeavoring to soothe them by their inferior attempts.

\section{FlaGG. A Year With the Birds. ${ }^{25}$}

The veery's usual call-note is a clearly whistled wheeu, which can be closely imitated; his song is a weird, ringing monotone of blended alto and soprano tones. Neither notes nor letters can tell one of its peculiar quality; it has neither break nor pause, and seems to emanate from no one place. If you can imagine the syllable vee-r-r-hu repeated eight or nine times around a series of intertwining circles, the description might enable you to recognize the veery's song.

Chapman. Handbook of Birds. ${ }^{21}$

Hold a stiff beech-leaf at right angles to your lips, and whistle softly a series of descending whee-u, whee-u, wheewhee-u's, and you will get a little of the reed-like quality and phrasing of the veery's song.

Florence A. Merriam. Birds of Village and Field. ${ }^{1}$

It is one of the simplest strains to be heard-as simple as the curves in form, delighting from the pure element of harmony and beauty it contains, and not from any novel or fantastic modulation of it,-thus contrasting strongly with such rollicking, hilarious songsters as the bobolink.

Burroughs. Wake Robin. ${ }^{5}$ 


\section{Veery. Wilson's Thrush. Tawny Thrush}

The veery . . . .sings at night also, and its weird, sweet strains floating through the woods at dusk, thrill one like the mysterious voice of a disembodied spirit.

\section{Neltje Blanchan. Bird Neighbors. ${ }^{23}$}

No sweeter note gives out Apollo's lyre,

None sweeter gives the shell his brother plays;

This gift of tawny thrush transcends the fire

Of any mortal soul that would aspire

To sing - as now I sing - the Veery's praise.

Selected.

\section{The Wood Notes of the Veery}

The moonbeams over Arno's vale in silver flood were pouring,

When first I heard the nightingale a long-lost love deploring,

So passionate, so full of pain, it sounded strange and eerie;

I longed to hear a simpler strain,- the wood notes of the veery.

The laverock sings a bonny lay above the Scottish heather, It sprinkles down from far away like light and love together; He drops the golden notes to greet his brooding mate, his dearie;

I only know one song more sweet,- - the wood notes of the veery.

In English gardens, green and bright and full of fruity treasure,

I heard the blackbird with delight repeat his merry measure; 


\section{Veery. Wilson's Thrush. Tawny Thrush}

The ballad was a pleasant one, the tune was loud and cheery,

And yet with every setting sun, I listened for the veery.

But far away, and far away, the tawny thrush is singing; New England woods, at close of day, with that clear chant are ringing;

And when my light of life is low, and heart and flesh are weary,

I fain would hear, before I go, the wood notes of the veery.

Henry Van Dyke.

\section{VIREO, RED-EYED “THE PREACHER"}

The easiest way to identify it, until it sings, is by the dark stripe through the eye, which is not found in the other vireos, while at short range and in good light the iris has a reddish tinge.

Parkhurst. The Birds' Calendar. ${ }^{31}$

Its back is olive, and its breast white, of such tints that when the sunlight is on the leaves, our vireo is well disguised, for its back looks like the upper side of the leaf, and its breast like the under side with the sun on it.

Selected.

The cowbird carefully attends the red-eyes, and deposits an egg in the nest; and the one ornithological wonder is that the bird is fool enough to take care of it. This it 


\section{Vireo, Red-Eyed. "The Preacher"}

does almost always, although evidence of rebellion is not wanting.

Аввотт. Birds About Us. ${ }^{27}$

His style of preaching is not declamation. Though constantly talking, he takes the part of a deliberative orator, who explains his subject in a few words and then makes a pause for his hearers to reflect upon it. We might suppose him to be repeating moderately, with a pause after each sentence, "You see it,-you know it,-do you hear me?--do you believe it?" All these strains are delivered with a rising inflection at the close, and with a pause, as if waiting for an answer.

FLAGG. A Year With the Birds. ${ }^{25}$

His song is a monotonous but cheerful monologue made up of short broken sentences, in triplets, given as he hunts over the branches for food. "Where's a worm? Where's a caterpillar? Where's a worm?" he queries as he goes, answering his own question very comfortably to himself. There is nothing ecstatic about his song. It seems merely the accompaniment of his occupation. He sings as a contented man whistles at his work.

Florence A. Merrian. Birds of Village and Field. ${ }^{1}$

Rain or shine, before noon or after, in the deep forest or in the village grove,--when it is too hot for the thrushes or too cold and windy for the warblers,--it is never out of time or place for this little minstrel to indulge his cheerful strain.

Burroughs. Wake Robin. ${ }^{5}$ 


\section{Vireo, Red-Eyed. "The Preacher"}

What are the materials of this basket hanging here in the fork of the maple! Let us unravel it. . . . Here are strips of white and yellow birch bark, aster calyxes, cobwebs, a blue-bottle fly, spider-egg silk tufts, slender roots, bits of pith, skeletonized leaves, pine needles, old cocoons of the tussock-moth, grass, caterpillar hairs, dandelion seeds, moss, and feathers. A broad piece of mottledgray paper-like substance forms the outside base of the nest. We might have been certain of finding this--a fragment of hornet's nest, one of the favorite fabrics of all the vireos. And what is this white weather-beaten fragment which crops out beneath it? A bit of newspaper! Further unravelling shows a number of similar pieces. .... In most of them the print was worn and illegible, and in others so fragmentary as to be without sense. But at length I came upon the sentiment . . . . . . the only perfect sentence to be found in all the print-my "preacher's" text-_"have in view the will of God."

Gibson. Sharp Eyes. ${ }^{32}$

No other . . . . speaks so clearly in our own tongue or seems so much to imply a listener. "Verily, verily: you know it: you see it: cheery are wé: we cheer you." Such is the melodious witness that seems to descend from heaven through the maple tree above us. "You are weary: we see it; listen to me: meekly: cheery are we: $\mathrm{O}$ why $i$ it: verily verily: . . . . there we owe it: believe me: 'tis real; we know it: Selah!" Mr. Beecher once remarked to me. . . "That little fellow has found a land of plenty up there, and he says grace like a little Christian at every mouthful."

Grbson. Starlight and Sunshine. ${ }^{33}$ 


\section{Vireo, Red-Eyed. "The Preacher"}

Upon the elm tree sprays The vireo rings the changes sweet, During the trivial summer days, Striving to lift our thoughts above the street.

Thoreau.

\section{VIREO, WARBLING}

The vireos, who live on measure-worms and similar morsels, are so exclusively devoted to foliage that they might well be called leaf-birds, and their tints harmonize strikingly with their habits. They may well be known as "greenlets."

Florence A. Merriam. Birds Through an Opera Glass. ${ }^{2}$

There is not a branch of any village maple, no drooping limb of any church-yard elm, no clustered trees upon the common, or stately rows of pines about our houses, but the warbling vireo knows full well; and at home the moment he reaches us, he goes forthwith upon his musical rounds, and, gentle as a spirit though he seems, dealing death to the insect hordes that Nature has here, too, given a home. . . . . The song is not interrupted and out of tune like the red-eye's song, and if you hear both . . . you will recognize them, the one as troubled water flowing over rocks, the other the quiet ripple of the meadow brooks.

Аввотт. Birds About Us. ${ }^{27}$

The song is a firm, rich, continuous warble with a singular alto undertone.

ChapMan. Handbook of Birds. ${ }^{21}$ 


\section{Vireo, Warbling}

Wilson Flagg represents it by the words, "Brigadier, Brigadier, Brigate," and designates the bird as "The Brigadier."

The nest is generally pendulous (with generally a free use of moss), and ambitiously and securely suspended at great elevations. In our elms I have seen one of these airy cradles at the very summit of one of the most gigantic, more than one hundred feet from the ground.

Nuttall's Ornithology. ${ }^{26}$

\section{VIREO, SOLITARY or BLUE-HEADED}

The solitary vireo may be distinguished from other vireos at a glance by its bluish head. It is to be sought in the woodlands.

M. A. Willcox. Common Land Birds of New England. ${ }^{29}$

In form its music resembles the red-eye's . . . . and the yellow-throat's. It has, too, . . . . a musical chatter--suggestive of the Baltimore oriole's--and a pretty trilled whistle. Wood bird as it is, it will sometimes permit the greatest familiarities. Two birds I have seen which allowed themselves to be stroked in the freest manner while sitting on the eggs, and which ate from my hand as readily as any pet canary.

Torrey. Chapman's Handbook of Birds. ${ }^{21}$

The solitary vireo builds a pensile nest . . . not so high from the ground as the yellow-throated vireo's, nor 


\section{Vireo, Solitary or Blue-Headed}

so exquisitely finished, but still a beautiful little structure of pine-needles, plant-fibre, dry leaves, and twigs, all lichen-lined and bound and rebound with coarse spiders' webs.

Neltje Blanchan. Bird Neighbors. ${ }^{28}$

\section{VIREO, YELLOW-THROATED}

This is undoubtedly the beauty of the vireo family.

Neltue Blanchan. Bird Neighbors. ${ }^{23}$

To distinguish it from both the warbling and the redeye, you have but to remember the yellow on its breast and its two strongly marked wing bars.

Florence A. Merriam. Birds of Village and Field. ${ }^{1}$

If the red-eye is a soprano, the yellow-throat is a contralto. He sings much the same tune, but his notes are deeper and richer, while they are uttered more deliberately and with greater expression. . . . "See me; I'm here; where are you?" he calls, and at intervals repeats his question in varying forms. Sometimes he astonishes us by an intricate liquid trill.

Chapman. Handbook of Birds. ${ }^{21}$

They [the red-eye and the yellow-throat], sing somewhat alike and yet differently, the advantage being with the yellow-throat, . . . . the red-eye . . . saying, "Do 


\section{Vireo, Yellow-Throated}

you hear me? Do you believe it?" and the yellow-throat, away up in the tree-top . . . . "Doubt it? 'deed I do!"

Аввотт. Birdland Echoes. ${ }^{28}$

They excel all their relations in architectural taste and skill, and construct a beautiful nest, outwardly ornamented with lichens, plant down and caterpillar's silk. It is altogether one of the prettiest nests to be found among our specimens of bird-architecture.

Minot. Land and Game Birds. ${ }^{20}$

\section{WARBLER, BLACK AND WHITE. BLACK AND WHITE CREEPER}

This little warbler is so uniformly striped with black and white that beginners often dub him "the little zebra bird."

Florence A. Merriam. Birds of Village and Field. ${ }^{1}$

Nine times out of ten these active little warblers are mistaken for downy woodpeckers, not because of their coloring alone but also on account of their common habit of running up and down the trunks of trees and on the under side of branches, looking for insects.

Neltje Blanchan. Bird Neighbors. ${ }^{23}$ 
Warbler, Black and White. Black and White

\section{Creeper}

His fine strain reminds me of hair-wire. It is unquestionably the finest bird-song to be heard. Few insect strains will compare with it in this respect; while it has none of the harsh, brassy character of the latter, being very delicate and tender.

Burroughs. Wake Robin. ${ }^{5}$

\section{WARBLER, BLACKBURNIAN}

In one's experience of warbler life, perhaps he touches high-water mark when he sees for the first time a perfect specimen of the Blackburnian warbler. To avoid the appearance of exaggeration I must refrain from adequately expressing the surprise and amazement elicited by this glowing coal of fire. . . . It might properly be named the conflagration warbler.

PARkhurst. The Birds' Calendar. ${ }^{31}$

The orange-throated warbler would seem to be his right name, his characteristic cognomen. . . . . The burn seems appropriate enough, for in these dark evergreens his throat and breast show like flame.

Burroughs. Wake Robin. ${ }^{5}$

The redstart's name of "candelita" might well be applied to the Blackburnian, for it is not only one of the most beautiful of the little warbler butterflies, but its flaming orange-red throat might easily suggest a torch in the forest.

Florence A. Merriam. Birds of Village and Field. ${ }^{1}$ 


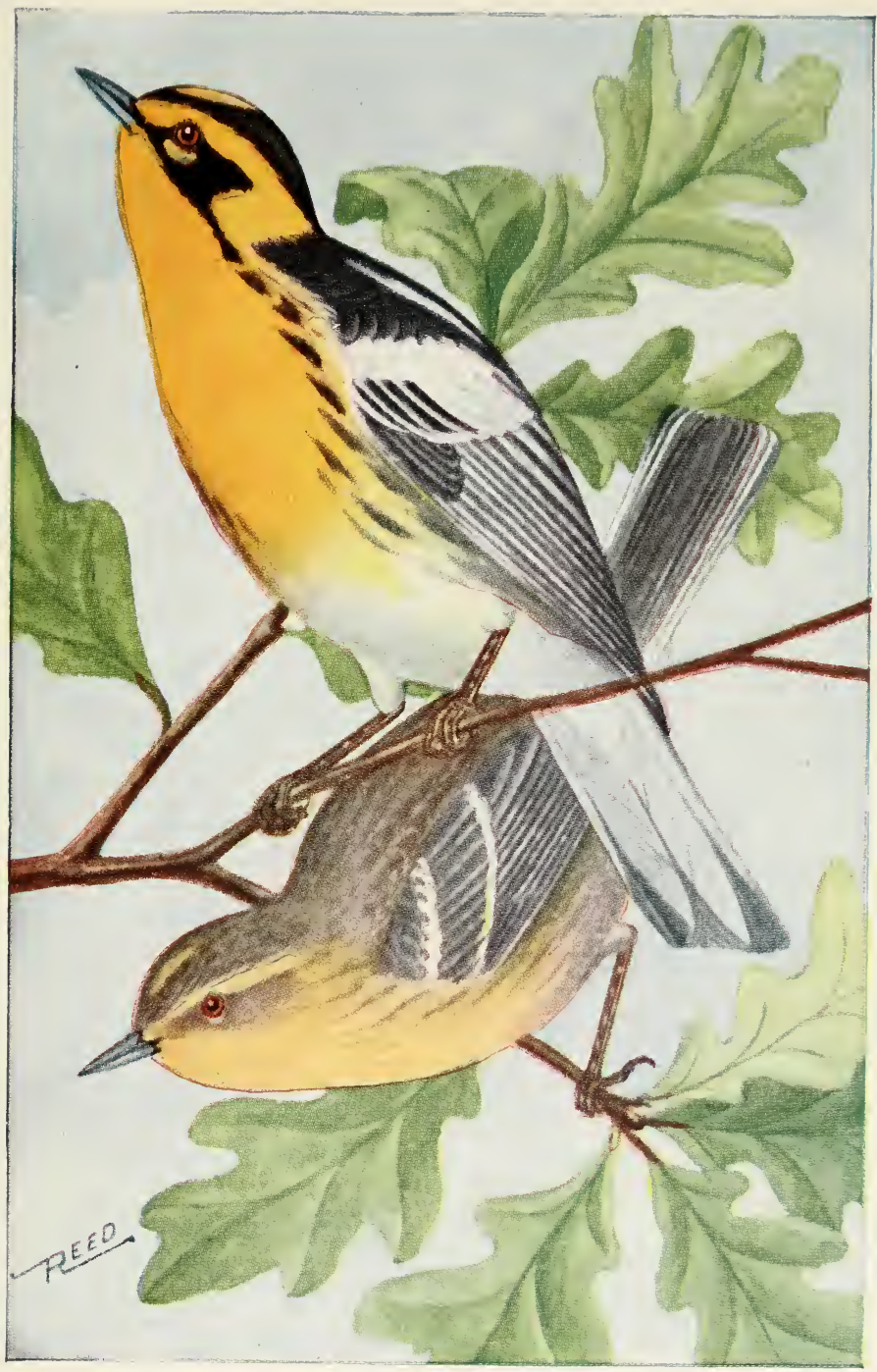





\section{WARBLER, BLACK-POLL}

The black-poll at first glance suggests the black and white creeper; but instead of a striped head, has a black cap.

It is said to be one of the most beneficial of warblers, fairly gorging itself on canker worms.

Florence A. Merriam. Birds of Village and Field. ${ }^{1}$

A dainty little fellow, . . . . he is almost hidden by the dense foliage on the trees by the time he returns to us at the very end of spring. . . . A faint "screep, screep" like "the noise made by striking two pebbles together," is often the only indication of the black-poll's presence.

Neltje Blanchan. Bird Neighbors. ${ }^{23}$

The song of the black-poll is weak, as if he had such a cold as to be almost inaudible.

Parkhurst. The Birds' Calendar. ${ }^{31}$

It resembles the syllables, tsi-tsi-tsi-tsi-tsi, repeated in a nearly unvarying tone.

Minot. Land and Game Birds. ${ }^{20}$

\section{WARBLER, BLACK-THROATED BLUE}

For a restful effect in pure white, blue and black, nothing could be finer than the "black-throated blue," as chaste and elegant as one could imagine, and with ample compensation for its colder tones in its grace of pose and motion.

Parkhurst. The Birds' Calendar. ${ }^{31}$ 


\section{Warbler, Black-Throated Blue}

It treats a tree as a staircase, hopping up a branch at a time, often stopping on the landings to follow the limbs out to their tips, and then, instead of vaulting into the air or dropping off in somersaults as do many of its acrobatic relatives, stops still, turns its head over and looks up before going on up the next stair.

Florence A. Merriam. Birds of Village and Field. ${ }^{1}$

\section{WARBLER, BLACK-THROATED GREEN}

This is one of the most welcome birds to the would-be ornithologist, because it is so easily recognized. The black inverted $\mathrm{V}$ of its under parts $(\Lambda)$, the yellow cheeks and large areas of white on the tail, are unmistakable.

Florence A. Merriam. Birds of Village and Field. ${ }^{1}$

The "black-throated greens" are, to me, with perhaps the exception of the pine warblers, the most attractive members of their family, on account, I think, of their pleasing, familiar, and oft-repeated songs, . . . which form so fitting an accompaniment to the whispering of the pines.

Мгnот. Land and Game Birds. ${ }^{20}$

Song:

Trees, trees, murmuring trees.--ToRREY. $\sqrt{ }$ Burroughs.

Cheese, cheese, a little more cheese.

Sleep, sleep, pretty one, sleep. 


\section{WARBLER, CHESTNUT-SIDED}

He is one of the rarest and handsomest of the warblers; his white breast and throat, chestnut sides, and yellow crown, show conspicuously. . . . A characteristic attitude of the male . . . . is a slight drooping of the wings, and tail a little elevated, which gives him a very smart bantam-like appearance.

\section{Burroughs. Wake Robin. ${ }^{5}$}

Like the redstart, it plumes itself on the fact that it does not need to rest. It is always on the lookout, always moving from point to point, as if animated by an abiding faith that there is merit in motion, even should nothing come of it.

Аввотт. Birdland Echoes. ${ }^{28}$

\section{WARBLER, MAGNOLIA or BLACK AND YELLOW}

His beautiful yellow breast is adorned with "a necklace and long pendants of black."

The one point to note, though, if we could but know it beforehand, is the white on the middle of the tail feathers, as most warblers wear their polka dots at the tips of their feathers.

Florence A. Merriam. Birds of Village and Field. ${ }^{1}$

The Magnolia has a shrill song, more than usually protracted on the approach of wet weather, so that the Indians bestow upon it the name of rain bird.

Nuttall's Ornithology. ${ }^{26}$ 


\section{WARBLER, MYRTLE or YELLOW-RUMPED}

The four yellow spots on crown, lower back, and sides are its distinguishing marks; and in the autumn these marks have dwindled to only one, that on the lower back or rump.

Neltje Blanchan. Bird Neighbors. ${ }^{23}$

In loose companies they forage in old fields and scrubby growths among the bayberry or myrtle bushes, which bear their favorite food [whence their name].

Chapman. Handbook of Birds. ${ }^{21}$

Yellow-rumped warblers are in place wherever you find them, and are as much at ease in the depth of the forest as about our garden fences.

Аввотт. Birdland Echoes. ${ }^{28}$

\section{WARBLER, NASHVILLE}

Its discoverer was first attracted to it by the singular noise which it made, resembling the breaking of small dry twigs, or the striking together of pebbles, for six or seven times in succession, and loud enough to be heard at a distance of thirty or forty yards.

Nuttall's Ornithology. ${ }^{26}$

Minot compares the first half of the song to the penetrating notes of the black and white warbler, and the last half to the twitter of the chipping sparrow. 
Warbler, Nashville

Though he has no marks, it is after all, a satisfaction to know that some warblers are plain. . . . His head is bluish gray, which is a mercy, for that is unusual in combination with the olive and yellow of his body.

Florence A. Merriam. Birds of Village and Field. ${ }^{1}$

\section{WARBLER, PARULA or BLUE YELLOW- BACKED}

It is one of the daintiest of the family, bound literally in blue and gold and white and in form and coloring one could hardly imagine anything more exquisite. A light ashy-blue spreads over the upper part of the body and wings, finely sprinkled with gold in the center of the back, while beneath it is snow-white except for the yellow and brownish band across the breast.

Parkhurst. The Birds' Calendar. ${ }^{31}$

Years ago when rambling in the woods . . . I caught sight of a bird that paused a moment on a branch above me, the like of which I had never before seen or heard of. It was probably the blue yellow-backed warbler, . . . . but to my young fancy it seemed like some fairy bird, so curiously marked was it, and so new and unexpected. . . . How the thought of it clung to me afterward! It was a revelation. It was the first intimation I had had that the woods we know so well held birds that we know not at all.

Burroughs. Wake Robin. ${ }^{5}$ 


\section{Warbler, Parula or Blue Yellow-Backed}

The song comes to me from amid the top branches of tall trees,--birch and poplar. It is an attractive song, though it has little theme--merely a rapid trill of some twenty sibilant notes delivered with a rising inflection; but the tones are sweet, and the effect is pleasing. The song is clearly an outburst of joyous emotion.

Nuttall's Ornithology. ${ }^{26}$

Hoffman likens the song to the winding up of a little watch.

\section{WARBLER, PINE. PINE CREEPER}

Here is a warbler, let it be recorded, that is fittingly named, for it is a denizen of pine woods only Its song recalls that of the junco and the chippy.

Neltje Blanchan. Bird Neighbors. ${ }^{23}$

Whoever has found it in its summer resorts will thereafter always associate its simple, sweet, and drowsy song with the smell of pines in a sultry day.

Parkhurst. The Birds' Calendar. ${ }^{31}$

They have always seemed to me quiet and rather indolent, and remarkably attentive to their dress. I have sometimes seen them pause, for at least fifteen minutes, to smooth their feathers or to rest, every minute "drawling out" their sweet note quite mechanically. At other times they are very active, and it is then impossible to keep sight of them for any great length of time.

Мinot. Land and Game Birds. ${ }^{20}$ 


\section{WARBLER, YELLOW. SUMMER YELLOW- BIRD}

From much living in the sunshine through countless generations, its feathers have finally become the color of sunshine itself, and in disposition, as well, it is nothing if not sunny and bright.

Neltje Blanchan. Bird Neighbors. ${ }^{23}$

The little warbler sings as he works, and his song seems the natural out-pouring of happiness akin to the opening of leaves and flowers.

Florence A. Merriam. Birds of Village and Field. ${ }^{1}$

It is amusing to watch the sagacity of this little bird in disposing of the eggs of the vagrant and parasitic cowbird. The egg . . . . too large for ejectment, is ingeniously incarcerated in the bottom of the nest, and a new lining placed over it, so that it is never hatched to prove the dragon of the brood. . . . . I have heard of two instances in which three of the yellowbird's own eggs were covered along with that of the cowbird. In a third, after a cowbird's egg had been thus concealed, a second was laid, which was similarly treated, thus finally giving rise to a three-storied nest.

Nuttall's Ornithology. ${ }^{26}$

SONG:

"Sweet-sweet-sweet-sweet-sweeter."

\section{Yellow Bird}

Yellow bird, where did you learn that song,

Perched on the trellis where grape vines clamber,

In and out fluttering, all day long,

With your golden breast bedropped with amber? 


\section{Yellow Bird}

Where do you hide such a store of delight,

$\mathrm{O}$ delicate creature, tiny and slender,

Like a mellow morning sunbeam bright

And overflowing with music tender!

You never learned it at all, the song Springs from your heart in rich completeness,

Beautiful, blissful, clear and strong,

Steeped in the summer's ripest sweetness.

To think we are neighbors of yours! How fine!

Oh, what a pleasure to watch you together, Bringing your fern-down and floss to reline The nest worn thin by the winter weather!

Send up your full notes like worshipful prayers; Yellow bird, sing while the summer's before you; Little you dream that, in spite of their cares Here's a whole family, proud to adore you!

Celia Thaxter.

\section{WARBLER, YELLOW PALM. YELLOW RED- POLL}

They are much more terrestrial in their habits than any of their immediate relations, and always are on or not very far from the ground.

Minot. Land and Game Birds. ${ }^{20}$

He has the same nervous peculiarity which, irrespective of family, seems to affect some birds, and, as though life were a matter of beating time, never ceases to wag his tail.

Chapman. Handbook of Birds. ${ }^{21}$ 


\section{Warbler, Yellow Palm. Yellow Red-Poll}

In the southern states the bird becomes particularly neighborly, and is said to enter the streets and gardens of towns with a chippy's familiarity.

Neltue Blanchan. Bird Neighbors. ${ }^{23}$

\section{WHIP-POOR-WILL}

Its habit, in common with the nighthawk, of perching lengthwise of the branch, and the perfect blending of the colors of its plumage with the bark and lichen patches make it well-nigh impossible to see this bird, even when there is no object to intercept the vision.

ADAPTED.

The whip-poor-will's day begins when the sun goes down. Then he passes out into bushy fields near his home, and, flying low, catches his supper on the wing.

Chapman. Handbook of Birds. ${ }^{21}$

The Delaware Indians said it was not safe to plant corn in the Delaware valley until these birds had arrived; after that there would be no frost.

Аввотт. Birds About Us. ${ }^{27}$

Where deep and misty shadows float,

In forest depths is heard thy note,

Like a lost spirit, earth-bound still, Art thou, mysterious whip-poor-will.

Selected. 


\section{WOODCOCK, AMERICAN}

They keep secluded in the woods and thickets till the approach of evening, when they sally forth . . . . in quest of worms and other insects on which they feed. . . . . They indicate their presence in all directions by the marks of their boring bills. . . . The sensibility possessed by the extremity of the bill is of such an exquisite nature that they are enabled to collect their food by the mere touch without using their eyes, which are set at such a distance and elevation in the back part of the head as to give the bird a remarkable aspect of stupidity.

Nuttall's Ornithology. ${ }^{26}$

How many evenings have I tempted malaria germs . to watch the woodcock perform his strange sky dance! He begins on the ground with a formal, periodic peent, peent. . . . . It is repeated several times before he springs from the ground and on whistling wings sweeps out on the first loop of a spiral which may take him three hundred feet from the ground. Faster and faster he goes, louder and shriller sounds his wing-song; then after a moment's pause, with darting, headlong flight, he pitches in zigzags to the earth, uttering as he falls a clear, twittering whistle. He generally returns to near the place from which he arose, and the peent is at once resumed as a preliminary to another round in the sky.

Chapman. Handbook of Birds. ${ }^{21}$

\section{WOODPECKER, DOWNY}

The little downy woodpecker is everywhere. There is not a tree too small for it to consider, and when trees fail altogether, it will climb over an old grape arbor and be happy in so artificial a surrounding.

Аввотт. Birds About Us. ${ }^{27}$ 


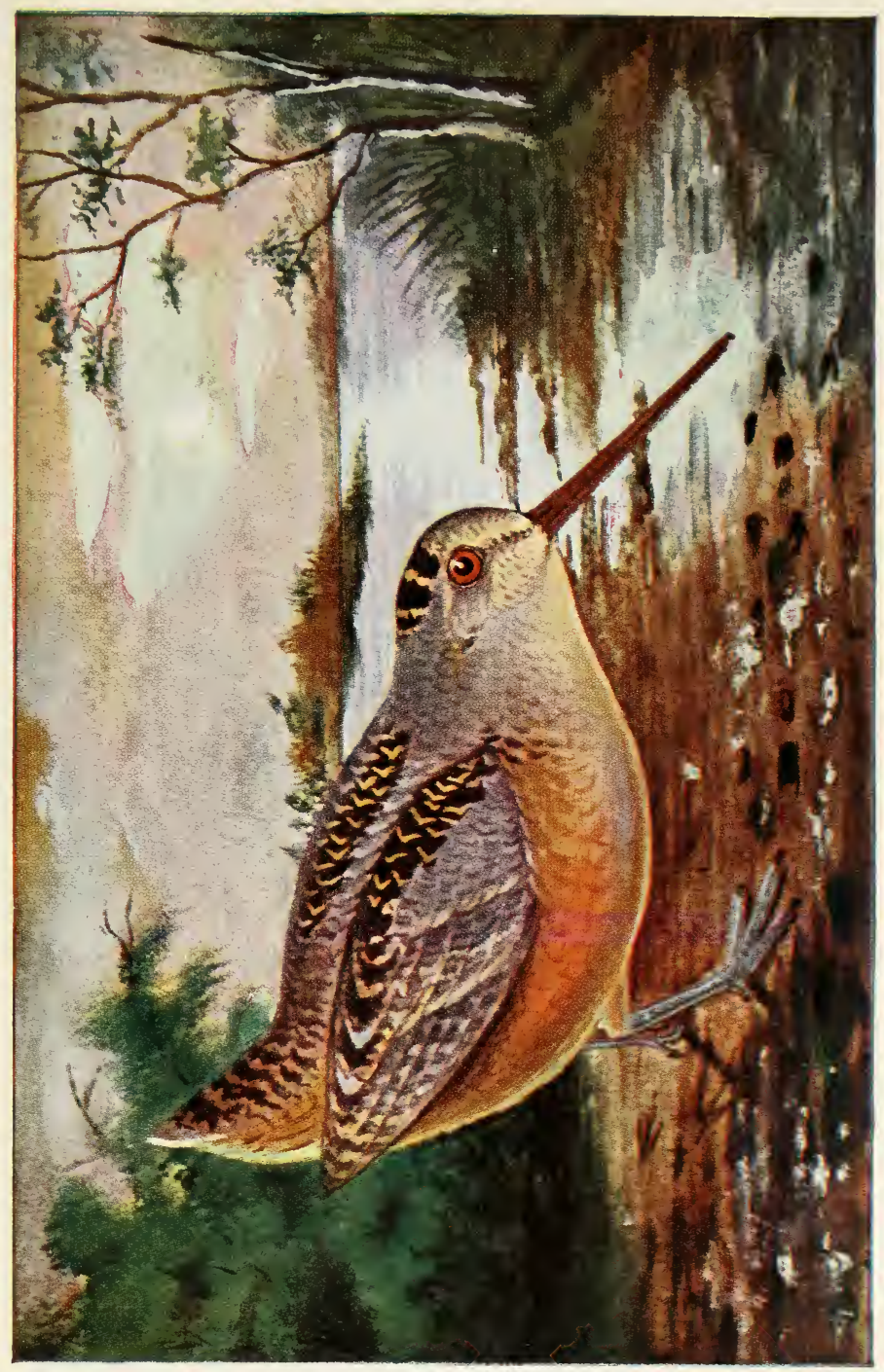





\section{Woodpecker, Downy}

How curious and exciting the blood-red spot on its hind head! It looks as if it had a black cassock open behind, showing a white under-garment between the shoulders and down the back.

Thoreau. Winter. ${ }^{15}$

In getting a living after their peculiar fashion, the woodpeckers have flattened their bodies for so many generations that it has become chronic in their physique, giving them a high-shouldered, long-waisted appearance that is far from beautiful.

Parkhurst. The Birds' Calendar. ${ }^{31}$

Seeing the birds about during snow storms, we wonder what becomes of them in the still colder nights, but the downy takes good care of himself. . . . . At night he is comfortably housed in a hole, which he digs expressly for that purpose. Always . . . so far as my experience goes, he places the entrance to his burrow so as to face the sunny south.

Florence A. Merriam. Birds of Village and Field. ${ }^{1}$

Like other woodpeckers, in the spring he beats a rolling tattoo on a resonant limb, sounding a reveille which is a credit to so small a drummer.

Chapman. Handbook of Birds. ${ }^{21}$

\section{How the Woodpecker's Crown Became Red}

The woodpecker was of great service to Hiawatha in the great struggle between that brave warrior and Pearl Feather, the great magician, who sent disease and pestilence among 


\section{Woodpecker, Downy}

the people. The conflict lasted for an entire day, and, at sunset, Hiawatha, wounded, weary, and despondent, paused to rest beneath a pine tree. Suddenly a woodpecker called to him from the branches overhead, telling him to aim his arrows at the roots of the tuft of hair upon his enemy's head, that being his only vulnerable point. Hiawatha acting upon this advice, with his three remaining arrows fatally wounded his mighty foe.

Then the grateful Hiawatha called the woodpecker to him, took a drop of the great Pearl Feather's blood and stained the tuft of feathers on the head of the little bird as a reward for his service.

"Even to this day he wears it, Wears the tuft of crimson feathers, As a symbol of his service."

AdAPTED.

\section{WOODPECKER. HAIRY}

It derives its name from the resemblance of some of the feathers on its back to hairs.

FLAGG. A Year With the Birds. ${ }^{25}$

The hairy woodpecker, like most of its relatives, is an exceedingly beneficial and useful bird, which rids our orchards and forests of innumerable injurious larvæ, like those of the boring beetles.

Selected.

As the best of us can speak only in the tongue we know, the woodpeckers announce their love on the drum When playing his piano, "the louder the noise produced the more satisfactory it appears to be to the performer."

Florence A. Merriam. Birds of Village and Field. ${ }^{1}$ 


\section{WREN, HOUSE}

Early some morning. . . there will go off under your window that most delightful of all alarm clocks-the tiny, friendly house wren. . . . . Like some little mountain spring that, having been imprisoned by winter ice, now bubbles up in the spring sunshine, and goes rippling along over the pebbles, tumbling over itself in merry cascades, so this little wren's song bubbles, ripples, cascades in a miniature torrent of ecstacy.

\section{Neltue Blanchan. Bird Neighbors. ${ }^{23}$}

The intense vitality which characterizes the life of birds finds its highest expression in the wrens. Perpetual motion alone describes the activity of these nervous, excitable little creatures. Repose seems to be out of the question; as well expect to catch a weasel asleep as to find a wren at rest.

Chapman. Bird Life. ${ }^{22}$

His nest, from preference near the house, is placed beneath the eaves. . . . or in a hollow orchard tree; also in the deserted cell of a woodpecker, and, when provided with the convenience, in a wooden box. . . . He will make it even in an old hat, nailed up, and perforated with a hole for entrance, or the skull of an ox stuck upon a pole; and Audubon saw one deposited in the pocket of a broken-down carriage . . . According to Wilson, an instance once occurred where a nest was made in the sleeve of a mower's coat, which was hung up . . . . in a shed near a barn.

Nuttall's Ornithology. ${ }^{26}$

It is well-known that the male wren frequently builds what are called "cock nests." It is simply so full of life 


\section{Wren, House}

and joy and of the propagating instinct, that, after the real nest is completed, and while the eggs are being laid, it gives vent to itself in constructing these sham or cock nests. . . The gushing ecstatic nature of the bird expresses itself in this way. Burroughs. Riverby. ${ }^{11}$

\section{WREN, WINTER}

The tail of the winter wren is comically short, and standing quite erect gives the little creature a peculiarly pert and saucy air, which seemed to Shakespeare so salient a feature when he alluded to

"The wren with little quill."

It is a specimen of highly concentrated nervous energy, bottled almost to bursting, explosively relieved in action and song--a bit of champagne with wings.

Parkhurst. The Birds' Calendar. ${ }^{31}$

It is such a friendly, jolly little bird that you are won by its confidence; but when you come to hear it sing, you are stirred by deeper emotions. The song is a marvel from such a little bird.

Florence A. Merriam. Birds of Village and Field. ${ }^{1}$

His song unites in a remarkable degree brilliancy and plaintiveness. I think of a tremulous vibrating tongue of silver. . . . He is the least ostentatious singer I know of. He does not strike an attitude, and lift up his head in preparation, and, as it were, clear his throat; but sits there on a $\log$ and pours out his music, looking straight before him, or even down at the ground. As a songster, he has but few superiors.

Burroughs. Wake Robin. ${ }^{5}$ 


\section{YELLOW-THROAT, MARYLAND}

Many a long year ago . . . I asked about this little bird, and was told that it was the "black-checked wren," and for years, until Audubon's seven volumes came to hand, I called it such. It is quite as good a name as the one given in the books.

Why "Maryland" should be tacked on to the popular name is not evident.

Аввотт. Birdland Echoes. ${ }^{28}$

The bright eyes of the male masquerader shine through his black mask, where he intently watches you from the tangle of syringa and snowball bushes; and as he flies into the laburnum . . . . you are so impressed with his grace and elegance that you follow too audaciously, he thinks, and off he goes. And yet this is a bird that seems to delight in being pursued. It never goes so far away that you are not tempted to follow it . . . . and it always gives you just glimpse enough of its beauties and graces before it flies ahead, to invite the hope of a closer inspection next time.

Blanchan. Bird Neighbors. ${ }^{23}$

In domestic relations, few birds are more affectionate. The male carries food most assiduously to his mate at the nest, caressing her, singing for her diversion, and guarding her from disturbance.

Florence A. Merriam. Birds of Village and Field. ${ }^{1}$

I have found several nests in skunk-cabbage plants, and still wonder if they were placed there for protection, for probably no animal is disposed to touch the plant if it can avoid it; but what of the sense of smell in the birds?

Аввотт. Birds About Us. ${ }^{27}$ 


\section{Yellow-Throat, Maryland}

In August they add a flight song to their repertoire. This is usually uttered toward evening, when the bird springs several feet into the air, hovers for a second, and then drops back to the bushes.

Chapman. Handbook of Birds. ${ }^{21}$

The ordinary song is said to vary greatly with locality, which may account for the quite different descriptions given.

Which way, sir? Which way, sir?

Burroughs.

"Wichity, wichity, wichity."

I beseech you, I beseech you, I beseech you. Chapman.

Where did you get it? Where did you get it? Аввотт.

I see, I see you, I see, I see you, I see, I see you. Flaga.

\section{Maryland Yellow-Throat}

While May bedecks the naked trees

With tassels and embroideries,

And many blue-eyed violets beam

Along the edges of the stream,

I hear a voice that seems to say,

Now near at hand, now far away,

Witchery--witchery--witchery.

An incantation so serene,

So innocent befits the scene:

There's magic in that small bird's note--

See--there he flits--the Yellow-throat;

A living sunbeam, tipped with wings,

A spark of light that shines and sings

Witchery--witchery--witchery. 


\section{BIBLIOGRAPHY}

(The figures in the text refer to corresponding figures in this list.)

1. Birds of Village and Field. . . . . . Florence A. Merriam (Houghton-Mifflin \& Co.)

2. Birds Through an Opera Glass. . . . Florence A. Merriam (Houghton-Mifflin \& Co.)

3. First Book of Birds. . . . . . . . . Olive Thorne Miller

(Houghton-Mifflin \& Co.)

4. A Bird-Lover in the West. . . . . . . Olive Thorne Miller

(Houghton-Mifflin \& Co.)

5. Wake Robin. . . . . . . . . . John Burroughs

(Houghton-Mifflin \& Co.)

6. Locusts and Wild Honey. . . . . . . . . John Burroughs

(Houghton-Mifflin \& Co.)

7. Signs and Seasons. . . . . . . . . John Burroughs

(Houghton-Mifflin \& Co.)

8. Winter Sunshine. . . . . . . . John Burroughs

(Houghton-Mifflin \& Co.)

9. Pepacton. . . . . . . . . . . . John Burroughs

(Houghton-Mifflin \& Co.)

10. Birds and Poets. . . . . . . . . . John Burroughs

(Houghton-Mifflin \& Co.)

11. Riverby. . . . . . . . . . . . . John Burroughs

(Houghton-Mifflin \& Co.)

12. Spring. . . . . . . . . . Henry D. Thoreau

(Houghton-Mifflin \& Co.)

13. Summer. . . . . . . . . . . . Henry D. Thoreau

(Houghton-Mifflin \& Co.)

14. Autumn. . . . . . . . . . Henry D. Thoreau

(Houghton-Mifflin \& Co.) 
15. Winter. . . . . . . . . Henry D. Thoreau

(Houghton-Mifflin \& Co.)

16. WhLDEN. . . . . . . . . . . Henry D. Thoreau

(Houghton-Mifflin \& Co.)

17. Excursions. . . . . . . . . . . . Henry D. Thoreau

(Houghton-Mifflin \& Co.)

18. Every Day Birds. . . . . . . . . Bradford Torrey

(Houghton-Mifflin \& Co.)

19. Chocorua's Tenants. . . . . . . . . Frank Bolles

(Houghton-Mifflin \& Co.)

20. Minot's Land and Game Birds. . . . . William Brewster

(Houghton-Mifflin \& Co.)

21. Handbook of Birds. . . . . . . . Frank M. Chapman

(D. Appleton \& Co.)

22. Bird LifE. . . . . . . . . . . Frank M. Chapman

(D. Appleton \& Co.)

23. Bird Neighbors. . . . . . . . . . . . . Neltje Blanchan

(Doubleday, Page \& Co.)

24. Birds That Hunt and Are Hunted. . . . . . Wilson Flagg (Educational Publishing Co.)

25. A Year With the Birds ............ Wilson Flagg (Educational Publishing Co.)

26. Nuttall's Ornithology.

(Little, Brown \& Co.)

27. Birds About Us.

Montague Chamberlain

(J. B. Lippincott Co.)

28. Birdland Echoes.

Charles Conrad Abbott

(J. B. Lippincott Co.)

29. Common Land Birds of New England.

M. A. Willcox

(Lothrop, Lee \& Shepard Co.)

30. New England Bird Life.

Stearns and Cowes

(Lothrop, Lee \& Shepard Co.)

31. The Birds' Calendar.

H. E. Parkhurst

(Chas. Scribner's Sons.)

32. Sharp Eyes.

Wm. Hamilton Gibson

(Harper \& Bros.)

33. Starlight and Sunshine.

Wm. Hamilton Gibson

(Harper \& Bros.) 


\section{INDEX OF BIRDS}

\begin{tabular}{|c|c|c|c|}
\hline & PAGE & & PAGE \\
\hline Bay-Winged Bunting & 140 & Flycatcher, Jeast & 48 \\
\hline Bee-Martin & 83 & Geese, Wild & 69 \\
\hline Bittern & 19 & Goldfinch & 70 \\
\hline Blackbird, Crow & 19 & Grosbeak, Pine & 72 \\
\hline Red-winged & 22 & Rose-breasted & 73 \\
\hline Rusty & 23 & Gull, American Herring & 74 \\
\hline Black and White Creeper & 167 & Hair-Bird & 130 \\
\hline Bluebird & 24 & Hang-Nest & 99 \\
\hline Bobolink & 30 & Hawks & 74 \\
\hline Bob White & 112 & Herons & 76 \\
\hline Bunting, Snow & 38 & Humming Bird, Ruby-throated & 76 \\
\hline Butcher Bird & 39 & Indigo Bird & 78 \\
\hline Catbird & 40 & Indigo Bunting & 78 \\
\hline Chat, Yellow-breasted & 46 & Jay, Blue & 79 \\
\hline Cedar Bird & 46 & Junco & 83 \\
\hline Cedar Waxwing & 46 & Kingbird & 83 \\
\hline Chebec & 48 & Kingfisher, Belted & 85 \\
\hline Chewink & 48 & Kinglet, Golden-crowned & 87 \\
\hline Chickadee & 49 & Ruby-crowned & 87 \\
\hline Cowbird & 54 & Lark, Horned & 88 \\
\hline Creeper, Brown & 55 & Linnet, Purple & 66 \\
\hline Crossbill, Red & 56 & Red-poll & 114 \\
\hline Crow, American & 58 & Loon, Black-throated & 89 \\
\hline Cuckoo, Black-billed & 63 & Martin, Purple & 90 \\
\hline Yellow-billed & 63 & Meadowlark & 92 \\
\hline Ducks & 65 & Nighthawk & 93 \\
\hline Eagle, Bald & 65 & Northern Shrike & 39 \\
\hline Finch, Purple & 66 & Nuthatch, White-breasted & 96 \\
\hline Firebird & 99 & Red-breasted & 98 \\
\hline Flicker & 66 & Oriole, Baltimore & 99 \\
\hline Flycatcher, Great-crested & 67 & Oven-Bird & 102 \\
\hline Olive-sided & 69 & Owls & 104 \\
\hline
\end{tabular}


Partridge

Peabody Bird

Ruffed Grouse

Pewee, Water

Phœbe

Wood

Pine Creeper

Quail

Redstart

Reed Bird

Rice Bird

Robin, American

English

Golden

Ground

Sand Martin

Sandpiper, spotted

Sapsucker, Yellow-bellied

Snowbird, Slate-colored

Snowflake

Sparrow, Chipping

Field

Fox

Grasshopper

Song

Tree

Vesper

White-crowned

White-throated

Summer Yellow Bird

Swallow, Bank

Barn

Cliff or Eave

Tree, White-bellied

Swift, Chimney

Tanager, Scarlet

Thistle Bird
Thrasher, Brown

Thrush, Hermit

Wilson's

Brown

Tawny

Wood

Titmouse, Blacked-capped

Towhee

Veery

PAGE

152

155

158

152

158

157

49

48

158

Vireo,Red-eyed,“The Preacher" 161

Warbling

164

Solitary or Blue-headed 165

Yellow-throated

166

Warbler, Black and White

167

Blackburnian

168

Black-poll

169

Black-throated Blue $\quad 169$ " " Green 170

Chestnut-sided

171

Magnolia or Black and Yellow

171

Myrtle or Yellow-rumped 172

Nashville

172

Parula or Blue yellowbacked

173

Pine

174

Yellow

175

Yellow Palm

176

Whip-poor-Will

177

Wild Canary

70

Woodcock, American $\quad 178$

Woodpecker, Downy 178

Hairy

180

Golden-winged $\quad 66$

Wren, House

181

Winter

182

Yellow-Throat, Maryland 183 


\section{INDEX OF AUTHORS}

Whose names are not included in the numbered list on the preceding pages.

\begin{tabular}{lr|lr} 
& PAGE & & PAGE \\
Abbott, Charles C. & 184 & Longfellow, & $15,57,60$ \\
Aldrich, T. B. & 26 & Lowell, 21, 26, 32, 76, 101, 112 \\
Arnold, Edwin & 149 & Merriam, Florence A. & 95,97 \\
Blanchan, Neltje & 25 & Miller, Olive Thorne & 72,117 \\
Brewer, & 148 & Nuttall, & 97 \\
Browning, & 15 & Parkhurst, H. E. & 95 \\
Bryant, & 36 & Rexford, E. E. & 27,35 \\
Burns, & 17 & Savage, M. J. & 45 \\
Burroughs, John & $21,25,63,132$, & Scollard, Clinton & 43,60 \\
& $147,170,184$ & Seton, Ernest Thompson & 139 \\
Chapman, Frank M. & $97,128,184$ & Sill, George I. & 134 \\
Cranch, C. P. & 33 & Spofford, Harriet Prescott & 25 \\
Emerson, 15, 21, $23,26,50,66$, & Stearns, & 97 \\
& $136,152,158$ & Stedman, E. C. & 119 \\
Fawcett, Edgar & 100 & Thaxter, Celia 60, 70, 124, 129, 175 \\
Flagg, Wilson & 37,184 & Thomas, Edith M. & $98,120,142$ \\
Foss, Sam Walter & 14 & Thoreau, 25, 49, 97, 135, 136, 153, \\
Gibson, Wm. H. & 147,158 & & 164 \\
Holland, J. G. & 78,96 & Torrey, Bradford & 95,170 \\
Holmes, & 33 & Trowbridge, J. T. & 109 \\
Hulbert, Wm. D. & 90 & Van Dyke,Henry 128, 138, 160, 184 \\
Larcom, Lucy & $72,100,122,132$, & Whittier, & 121 \\
& $143,147,154$ & Wilson, & 96
\end{tabular}




\section{The REED NATURE SERIES COLORED ILLUSTRATIONS}

\section{Bird Guide.-Land Birds. By Chester A. Reed.}

A pocket guide, size $3 \frac{1}{2} \times 5 \frac{1}{2}$ in., to all the Song and Insectivorous Birds found east of the Rocky Mountains. With text and an accurately colored illustration of each species, 210 birds. A wonderful book of which 200,000 copies have already been sold. Cloth binding, 75 cents; flexible leather, $\$ 1.00$.

\section{Bird Guide-Water Birds. By Chester A. Reed.}

The companion book to the above, describing and illustrating in color every Water Bird, Game Bird and Bird of Prey found in eastern North America, -230 birds. The two books include every bird. Bound in cloth, $\$ 1.00$; flexible leather, $\$ 1.25$.

\section{Nature Studies-Birds. By Chester A. Reed.}

A juvenile bird book used largely in fourth and fifth grades. Has interesting stories of forty birds and colored illustrations of each. Cloth bound; 112 pages, $5 \times 7 \frac{1}{2}$ in., 60 cents; postage 10 cents.

\section{Nature Studies in Field and Wood. By Chester A. Reed.}

Designed to create an interest in Nature Study by calling attention to the many wonderful creatures to be found and their exceedingly interesting manners of living. Handsomely illustrated in color and black and white. 112 pages, $5 \times 7 \frac{1}{2}$ in. 60 cents net; postage 10 cents.

Camera Studies of Wild Birds. By Chester A. Reed.

The life stories of a great many of our native birds, beautifully illustrated by reproductions from photographs of the living, wild birds taken in the field. Probably comprises the most complete collection of nature photographs ever published in one volume. Cloth bound; 350 pages, $5 \times 7 \frac{x}{2}$ in. Over 200 illustrations. $\$ 2.00$ net; postage 20 cents.

\section{North American Birds' Eggs. By Chester A. Reed.}

The only work of the kind, describing all North American Birds and giving an illustration, full size, of the egg of each species made from photographs of authentic specimens. 350 pages, $6 \times 9$ in. $\$ 2.50$ net; postage 25 cents

\section{The Reed Nature Glass.}

A glass made expressly for and imported by us. Designed for bird study but, of course, is equally good for any other purpose to which field glasses are adapted. We have seen nothing at the price equal to it in field and sharpness. Magnifies 3 diameters. Comes in a leather case and with carrying strap. Finish black. $\$ 5.00$ postpaid.

CHARLES K. REED, Worcester, Mass. 






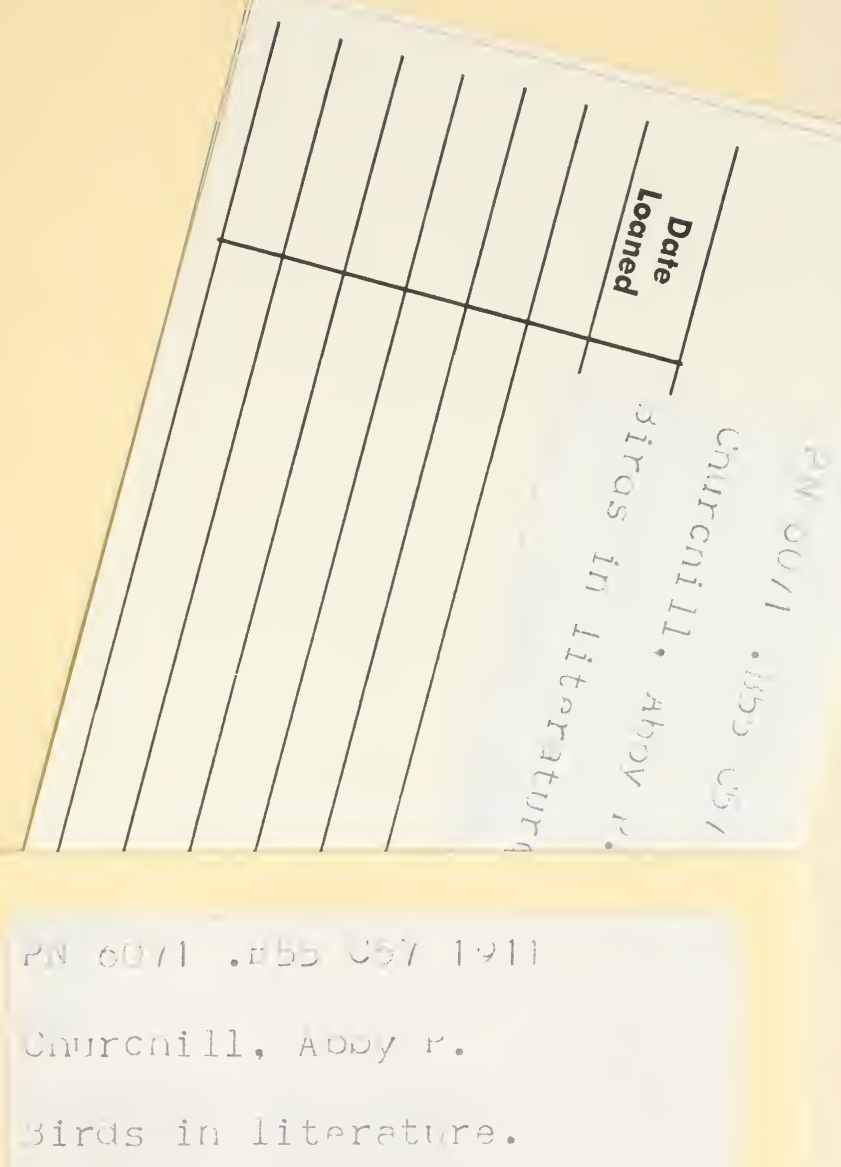


